\title{
عادات العقل والذكاي الروحي فى علاقتهما بالدافعية للتعلم لدى طلاب كلية التربية بسوهاج
}

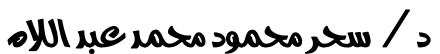

\author{
مدرس علم النفس التربوى- كلية التربية جامعة سوهاج
}

هدفت الدراسة الحالية إلى معرفة طبيعة العلاقة بين عادات العقل وكل مسـن: الـــكاء الروحسى هـ

و الدافعبة للتعلم لدى طلاب كلية التربية بسوهاج، والكشف عن الفروق بين الذكور والإناث فحى كل مــن: عادات العقل و الذكاء الروحى و الد/فعية للتعلم، إضافة إلى بحث إمكانبة التتبؤ بالدافعية للتعلم من خــال عادات العقل والذكاء الروحى لدى الطلاب. ولتحقيق أهداف الدراسة أعدت الباحثة مقياسا للدافعبة للتعلم،

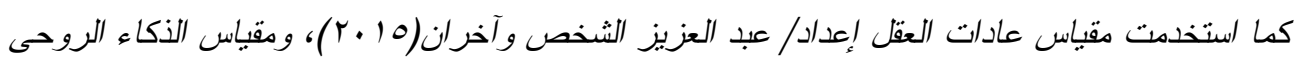

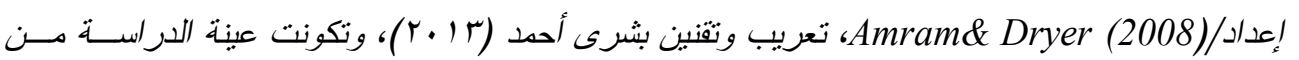

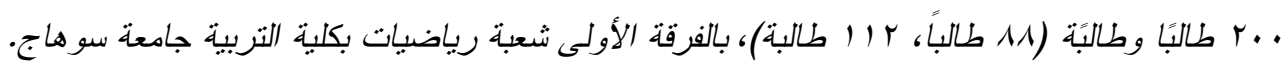
وتوصلت الدراسة إلى وجود علاقة إرتباطية موجبة ذات دلالة إحـصائبة عنــ مسستوى (1 . . ) بــين

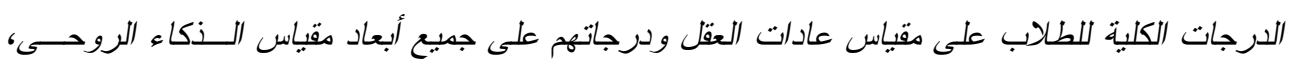
وكشفت النتائج وجود علاقة إرتباطبة موجبة دالة إحصائيا عند مستوى (1 . . ) بــين الــرجات الكليـة للطلاب على مقياس عادات العقل ودرجاتهم الكلية على مقياس الدافعية للتعلم، كما أظهرث نتائج الدرسة وجود علاقة إرتباطية موجبة دالة إحصائيا عند مستوى (1 . ..) بين مجموع الدرجات الكلية للطلاب على

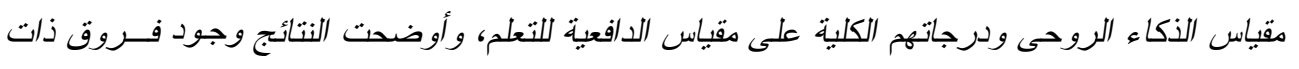
دلالة إحصائيا عند مستوى (0. . . ) بين الذكور والإناث فى الدرجة الكلية على عادات العقـلـ لــصالح

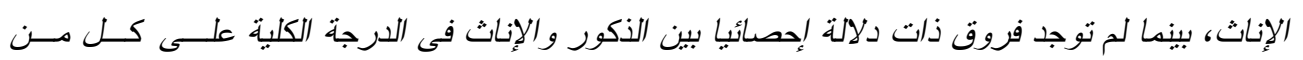

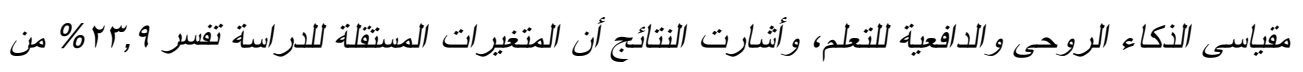

$$
\text { التغيرات الحادثة فى الدافعية للتعلم. }
$$

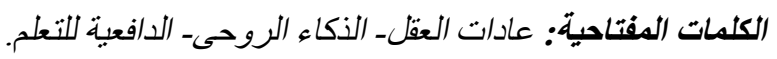

\section{Abstract:}

The current study aimed to know the relationship between habits of mind, spiritual intelligence and Learning motivation among Sohag faculty of education students, and to discover the differences between males and females in each of: habits of Mind, Spiritual Intelligence and learning motivation, also to explore the possibility of predicting the learning motivation through habits of mind and 


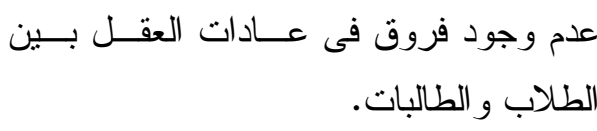

بينما توصلت در اســات كـل مــن

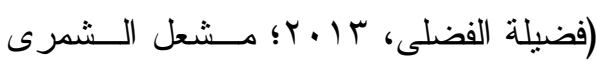

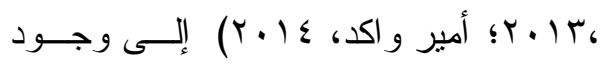

فروق فى بعض عادات العقل بــين الــذكور

و الإناث لصالح الذكور • فى حــين أثنــارت

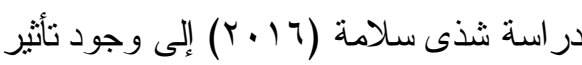
لللنوع في عادة التحكم بالتهور لصالح الإناث، لـاثل

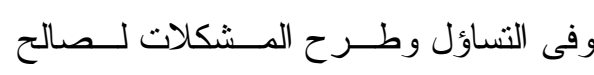

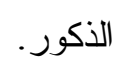

ويوضح مارزانو (·. ..ب: 90 () أننا

نلجأ إلى استخدام العادات العقلية عندما نكون

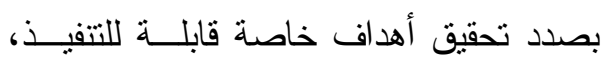
ومنل هذه الأهداف الخاصة تمنل أهم مصادر الدافعية و النشاط.

كما يـشير Tishman(2000) إلـى

أهمية وجود الدافعية لدى الفرد لكـى يــتـعلم

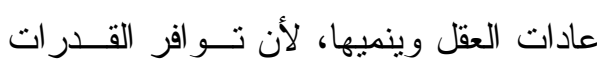
ومهار ات التفكير لدى الفرد يعتبر غير كاف لفئ لان

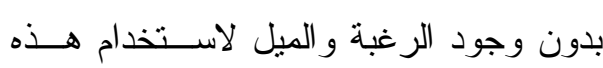
العادات العقلية.

فلقد أوضحت دراسة Culler(2007)

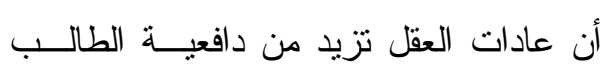

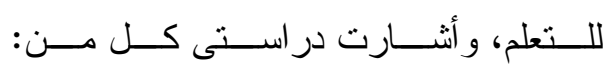

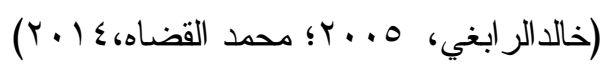

وتدعو أساليب التربية الحديثة إلى أن

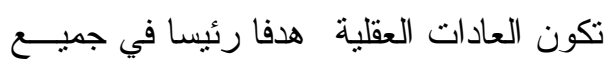

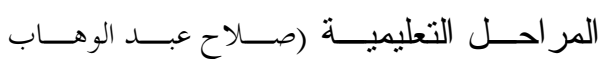

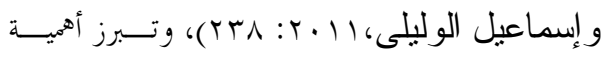

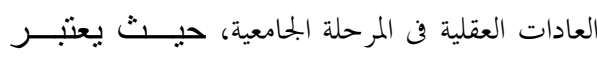

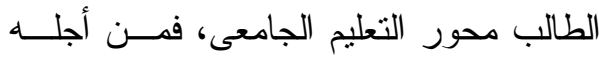

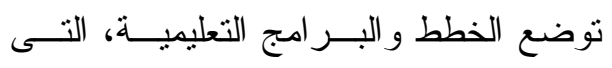

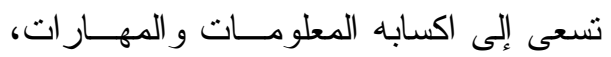
بالإضافة إلى إكسابه عادات عقلية فعالة، مما لـابه

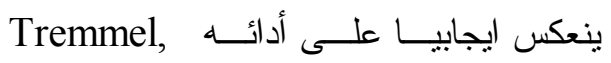
.(2002:31-32)

فلقد أثثــار صــلاح الــدين محمـــود

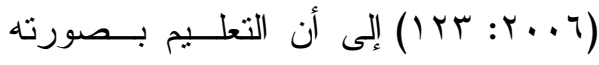

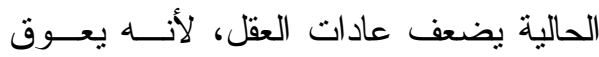

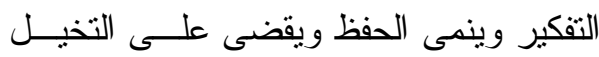
و التصور الذهنى لدى الطلاب، ونتيجة لذلك يأتي العديد من المتعلمـين إلـى المر احــل

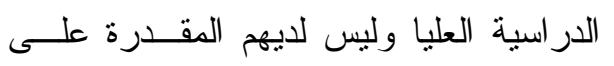
التفكير و إعمال عادات العقل، بل يستطيعون فقط حفظ المعلومات و استظهار ها. وعن الفروق بين الذكور والإناث فى

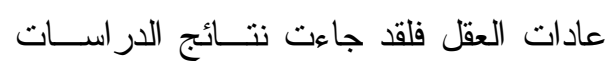
متتاقضة، فلقــــ نوصــلت در اســات كــل

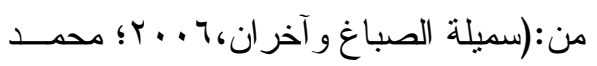

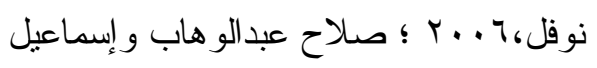

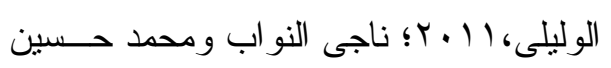

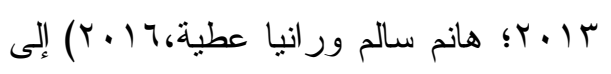




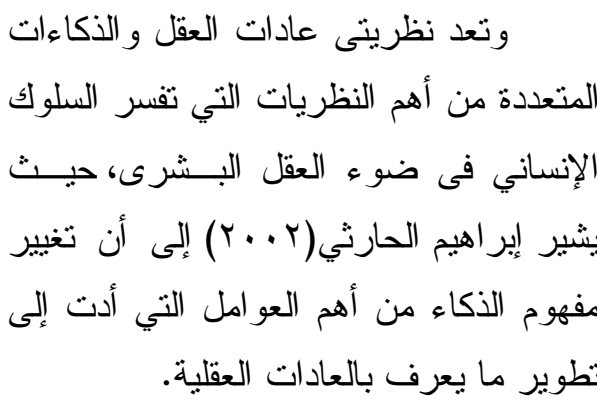

فلقد أضاف Gardner حرف S فـى

اللغة الإنجليزية على كلمـة Intelligence (ذكاء) لتــصبح Intelligences (ذكــاءات)

وبذلك يكون قد خرج عن النظــــة التقليديــة

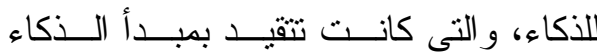

الأحادى (سيلفر وسترونج، ج . . Y: V V).

وتُشير نظرية Gardner إلى وجــود

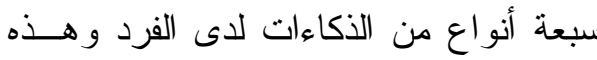

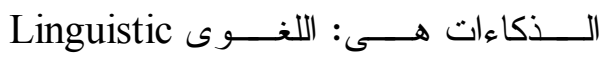

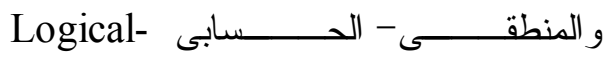

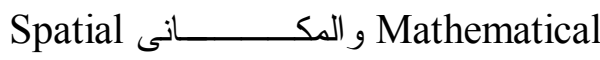

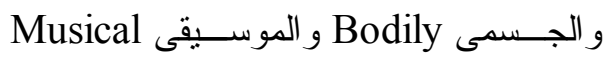

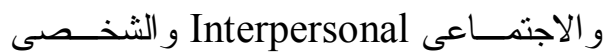
Gardner كمــــا أضـــاف. Intrapersonal

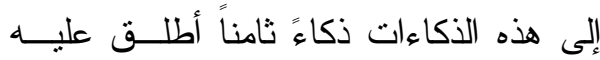

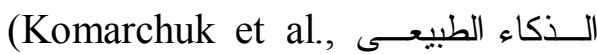
(2500: 2000، وتزك المجال متسعا لإضافة

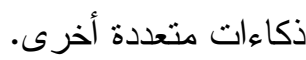

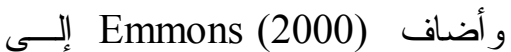
قائمة الذكاءات الني ابتدأها Gardner نوعا

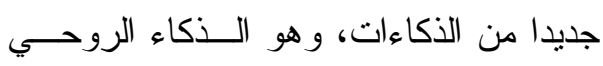

إلى وجود علاقة ارتباطيــة موجبـــة ودالــــة إحصائيا بين عادات العقل و الدافعية للإنجاز .

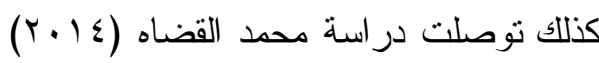
إلى أن عادات العقل تشهم فى التتبؤ بدافعيــة

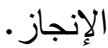

وعن الفروق بين الذكور والإناث فى

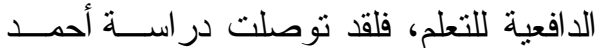

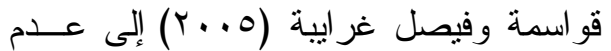
وجود فروق دالة إحــصائيا بــين الـــكور و الإناث فى الدافعية للتعلم، بينمـــا أثـــارت

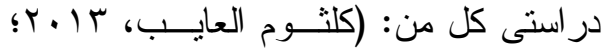

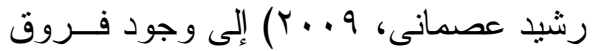
بينهما فى الدافعية للتعلم لصالح الإناث.

كما تزى عادات العقــلـ ان الدافعيــة تلعب دورا فى إخرج السلوك الذكى، فهنــالك كثير من الأفر اد لديهم القدرة علـــى النجــــاح

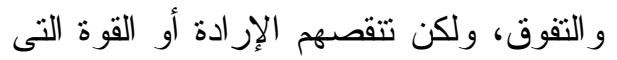

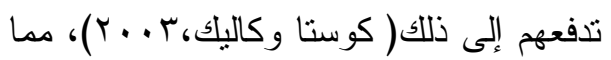
يشير إلى اعتــر اف عــادات العقــل بــدور

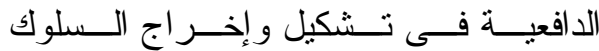
الذكى، لأن القدر ات وحدها لا تكفى لتـشكيل

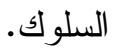
ولقد اشتق مفهوم عادات العقل مــن

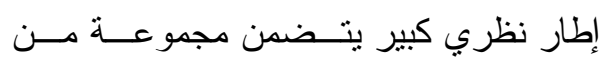
النظريات من أهمها نظريات الذكاء، ونماذج هيري معالجة المعلومات(Compbell, 2006:1). 
در استى كل من: (مشعل الـشمري، با • r)، (صلاح عبد الوهــاب و إبـــماعيل الــوليلي

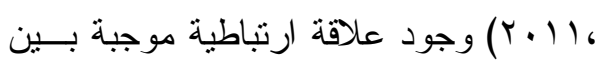

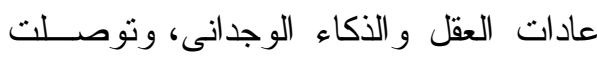

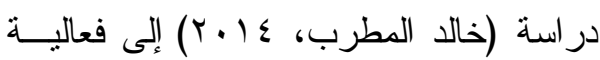
برنامج قائم على عادات العقل فــى تـميـــة الأكاء المنطقي /الرياضي.

و اسفرت دراسة (حازم عناقرة وزياد

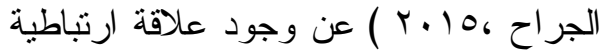
موجبة بين عادات العقل و الذكاءات المتعددة (اللغوي، و المنطقي- الرياضي، و البصري-

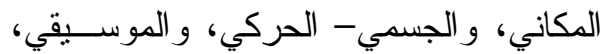

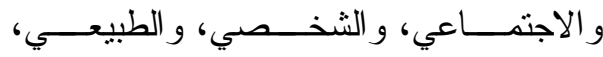
و الوجودي).

ولقد تتاولت بعض الدر اسات العلاقـــة

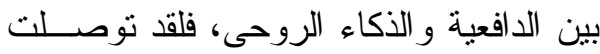

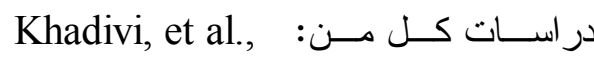
؛ Nobari\&Shokri, 2014; 2014)

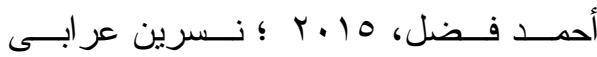
و آخران، 17 . (Y) إلى وجود علاقة ارنباطية موجبة بين الذكاء الروحي و الدافعية للإنجاز . أما عن الدر اسات التى نتاولت عادات العقل و الدافعية، فقد تتاولت عادات العقل فى علاقته بالدافعية للانجاز كما فى در اســتى:

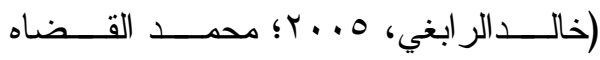

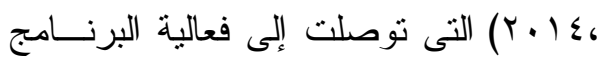

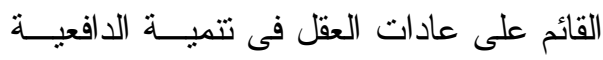

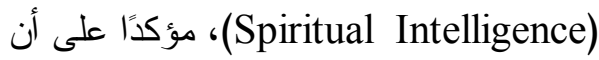

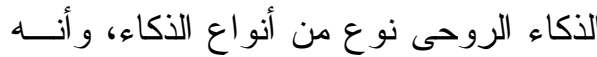
يطابق معيار جاردنر للذكاء. ويقصد بالذكاء الروحي القدرة علـى

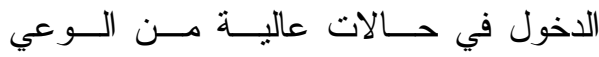
الروحي، و القدرة على اســتخدام الـــصادر الروحية في مواجهــة المـشـاكل اليوميــة، و القدرة على الاندماج في السلوكيات الفاضلة (كالتسامح، و الاعتر اف بالجميل، و التواضع،

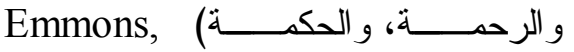
.$(2000: 10)$

وعن الفروق بين الذكور والإناث فى الذكاء الروحى، فلقد تباينت نتائج الدراسات، حيث أثشارت درسات كل من: (حنـان زايد

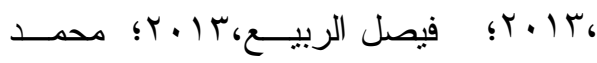

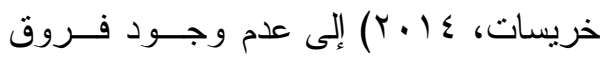

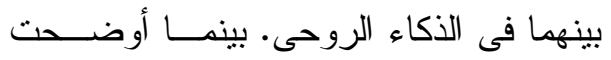

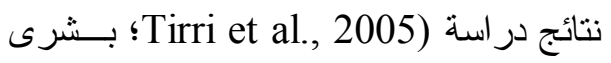

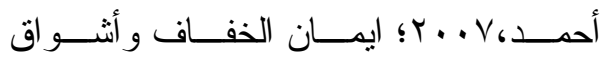

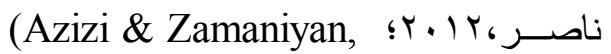
2013 وجود فروق فى الذكاء الروحى وفقا للنوع لصالح الإناث، بينما توصلت دراستى كل من : Neto et al., 2008; Gupta, (2012 إلى وجود فروق بينههــا لــصالح

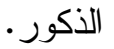
وتتاولت بعـض الدر اســات علاقــة عادات العقل ببعض الذكاءات، فلقد كـشفت 
ولم تتتاول الدر اسات السابقة -على حد علـــ الباحثة- علاقتها بالدافعية للتعلم.

كما تتاولت الدر اسـات السابقة علاقـــة

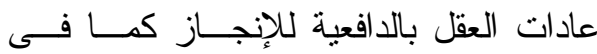

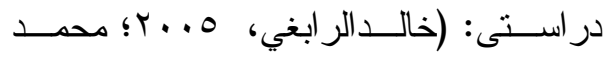

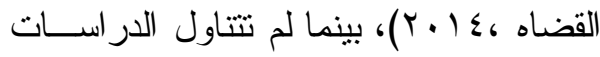

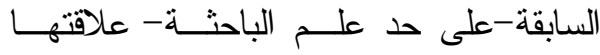

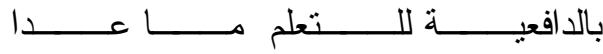
در اسة(2007)Culler)

أما عن علاقة عادات العقل بالــذكاء

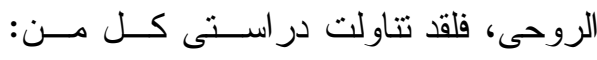
(مشعل الثمري، إ ـ ץ؛ صلاح عبد الوهاب

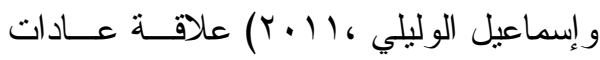
العقل بالذكاء الوجدانى، وتتاولــت در اســـة:

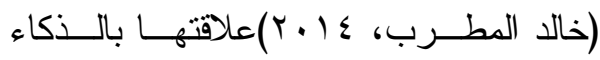

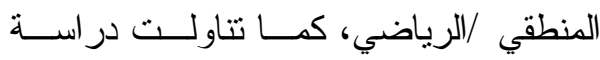

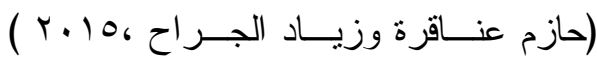

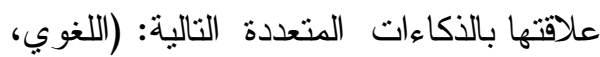
و المنطقي- الرياضي، و البصري- المكاني،

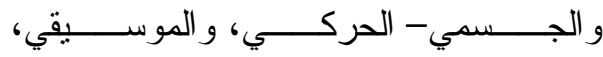

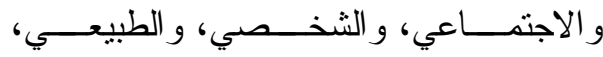
و الوجودي)، ولم تتعرض الدر اسات الــسابقة -على حد علم الباحثة- لدر اسة العلاقة بــين

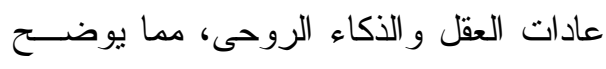
اهمية الدراسة الحالية التى تتتاول كل مــن: عادات العقل و الــــكاء الروحسـى و الدافعيـــة
للانجاز ، ولم يتم تنتـاول عادات العقـلـ فــى

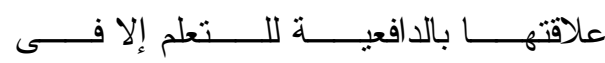
در اسةCuller) التى توصلت إلى أن عادات العقل تزيد من دافعية الطالب للتعلم. مما سبق تتضـح حاجتتا إلى دراســـة

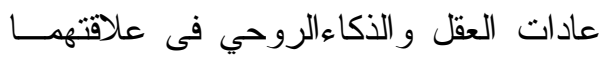
بالدافعية للتعلم لدى الطلاب.

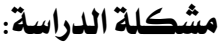

من خلال ملاحظة الباحثة لــسلوكيات

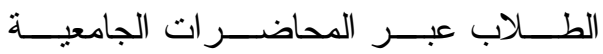
و المقابلات الثخصية و المناقثنات و الأنـشطة الجامعية المختلفة، لاحظت الباحثـة تـدنى

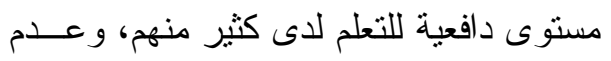
اهتمامهم بتحسين مستو اهم التعليمى و اكتة دــاء

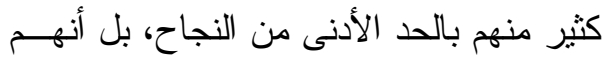

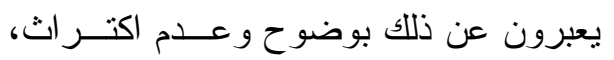
على الرغم من امتلاكهم القــــرات العقليـــة و المعرفية التى تؤه هلهم للتفوق و التميز . وبالرغم من أهمية الدافعية للتعلم، فإن الدراسات السابقة لم نتتاول علاقتها بكل من من

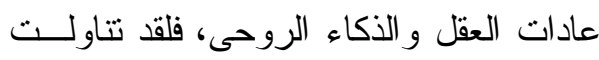
بعض الدراسات العلاقة بين الدافعية للإنجاز و الأكاء الروحى كما فى در اسات كل من: Khadivi, et al., 2014) ; أحمد فـضل، Nobari\&Shokri, 2014;

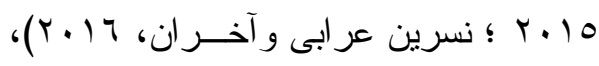
للتعلم. 


$$
\begin{aligned}
& \text { ع-هل يختلف كل من: عادات العقل و الذكاء }
\end{aligned}
$$

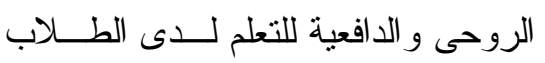

$$
\begin{aligned}
& \text { باختلاف النوع الاجتمــاعى (ذكـــور - } \\
& \text { إناث) لدى طلاب كلية التربية بسو هاج؟ }
\end{aligned}
$$

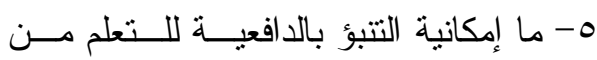

$$
\begin{aligned}
& \text { خلال عادات العقل و الذكاء الروحى لدى بلى الديه } \\
& \text { طلاب كلية التزبية بسوهاج؟ }
\end{aligned}
$$

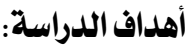

تهدف الدر اسة الحالية إلى:

1-التعرف على طبيعة العلاقة بين عـادات

العقل و الذكاء الروحى لدى طلاب كليـــة

$$
\text { التربية بسو هاج. }
$$

r- الكثف عن طبيعة العلاقة بين عـادات

العقل و الدافعية للتعلم لدى طــلاب كليــــة

$$
\text { التزبية بسو هاج. }
$$

r- التعرف على طبيعة العلاقة بين الـــكاء الروحى و الدافعية للتعلم لدى طلاب كلية

$$
\text { التربية بسو هاج. }
$$

ع - الكثف تأثير النوع (ذكور - إناث) فـى

كل من: عادات العقل و الذكاء الروحسى لتصى

و الدافعية للتعلم لدى طلاب كلية التربيــة

$$
\text { بسو هاج. }
$$

0- بحث إمكانية التتبؤ بالدافعية للتعلم مـن

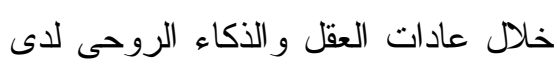

$$
\text { طلاب كلية التزبية بسو هاج. }
$$

وبما أن العـادات العقليــة و الــذكاء

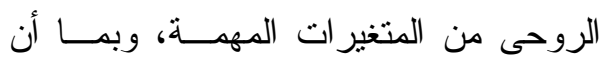

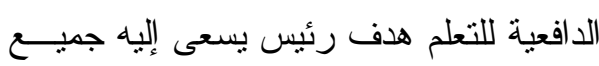

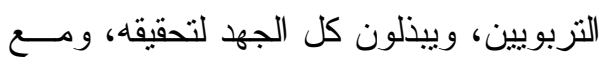

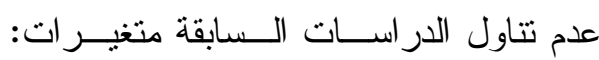

العادات العقلية و الذكاء الروحسـى و الدافعيــة

للتعلم مجتمعة-على حد علم الباحثة- تتضح

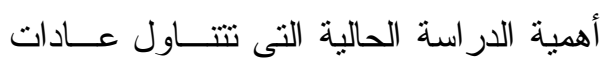

العقل و الذكاء الروحي فى علاقتهما بالدافعية

$$
\text { للتعلم لدى الطلاب الجامعيين. }
$$

ويمكن صباغة مشكلة الدراسة فى الإجابــة

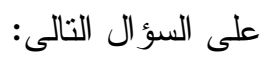

ما طبيعة العلاقة بين عادات العقــل

و الذكاء الروحى و الدافعية للتعلم لدى طلاب

$$
\text { كلية التزبية بسوهاءج }
$$

ويتفرع منه الأسئلة التالية:

1- ما طبيعة العلاقة الارتباطية بين عادات

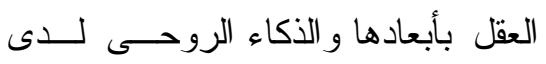

$$
\text { طلاب كلية التربية بسو هاج؟ }
$$

r- ما طبيعة العلاقة الارتباطية بين عادات

العقل و الدافعية للتعلم لدى طلاب كليــة

$$
\text { الثربية بسو هاج؟ - ماجي }
$$

r- ما طبيعة العلاقة الارنباطية بين الــذكاء

الروحى و الدافعية للتعلم لاى طلاب كلية

$$
\text { التربية بسو هاج؟ }
$$




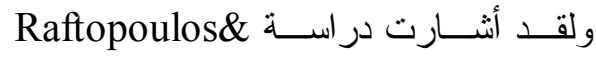
Bates(2011) الروحانية تساعد على تعزيز الثعور بالتفاؤل

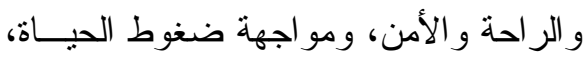
وزيادة الوعي الذاتي و الكفاءة الذاتية. كذللك فان الدافعية مكون جوهرى فى ولى

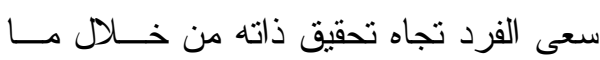

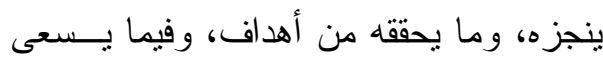

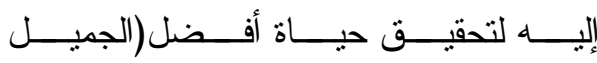

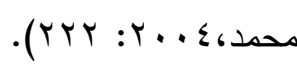

ولقد اجمع علمــاء الــنفس علــى أن الدافعية ركيزة أساسية، وشرط رئيس للتعلم

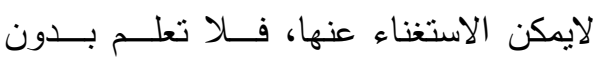

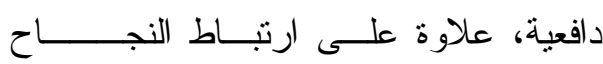

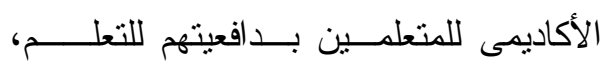

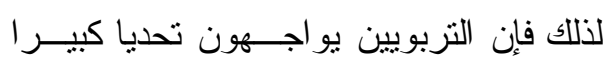
للحفاظ على دافعية التتعلم لدى المـتعلم، لأن

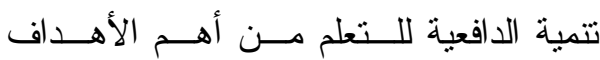

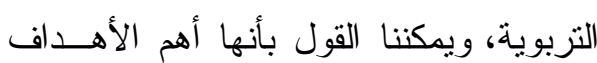
التى يسعى التزبويون لتحقيقها. كما تقدم الدراسة الحالية إطار الظريا لنونيا

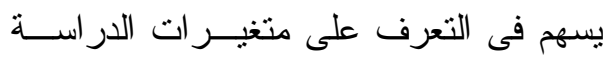

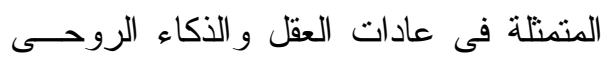

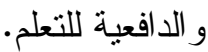

كذلك يمكن الاستفادة مـن توصــبات

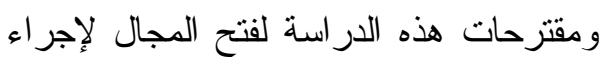

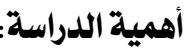

تتقسم أهمية الدراسة إلى نوعين هما:

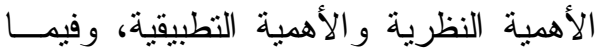

$$
\text { يلى شر ح لهما: }
$$

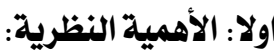

تمثلت الأهميــة النظريـــة للار اســـة

الحالية فى أهمية المتغيرات التى تنتاولهــا،

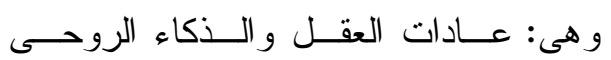

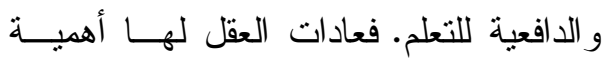
كبيرة، حيث أنها تؤثر في كل شيء يقوم به

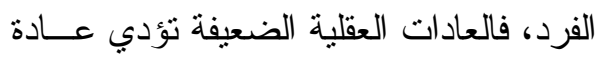
إلى تعلم ضعيف، بغض النظر عن مسـستوى

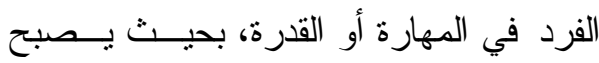
المتعلمون المهرة غير فعالين إذا لم يقومــو المها

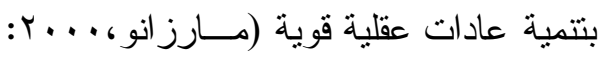
اب)، لأن عادات العقل تمثــلـل الــسلوكيات الذكية التى يستخدمها الفرد في حل مشكلاته وتتظيم تعلمه(Compbell, 2005:1). كما أن الذكاء الروحى له أهمية كبيرة

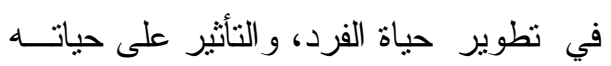

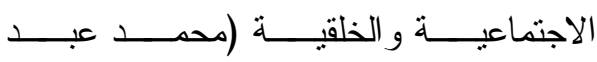

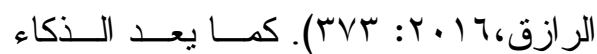

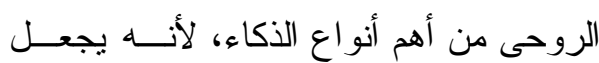

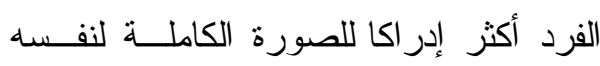

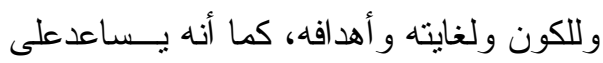
رؤية الجانب المبهج للأشياء، وزيادة السلام

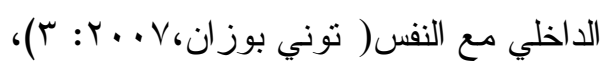


دون غيره أو قدرته على تعديله و التقدم بـــه نحو تصنيفات مستقلة"

وتعرف إجر ائيا بالدرجة التي يحصل

علبها الطالب في مقيــاس عــادات العقــل بأبعاده، المستخدم في الدر اسة الحالية.

الأكاء الروحى Spiritual Intelligence:

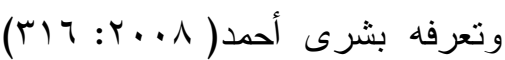

بأنه "القدرة على التصرف بعاطفة وحكمـــة أثناء محاولة تحقيق الاتزان (السلام الداخلى

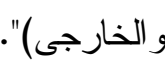

ويعرف إجرائيا بالدرجة التي يحصل

عليها الطالب في مقياس الــذكاء الروحسىى

بأبعاده، المستخدم في الار اسة الحالية.

\section{الدافعية للتعلم Learning Motivation:}

تعرفها الباحثة بأنها الطاقة الداخلية أو

الخارجية المحركة لسلوك المتعلم فى الموقف

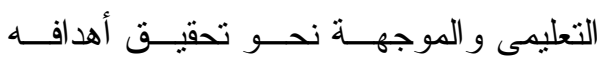

وتُعرف إجرائيا بالدرجة التي يحصل

التعليمبة.

عليها الطالب في مقياس الدافعية للتعلم، المعد

$$
\text { و المستخدم في الدر اسة الحالية. }
$$

الإطار النظري:

عادات العقل Habits of mind :

إن العقل هـــو أداة الإنــسان للــتعلم

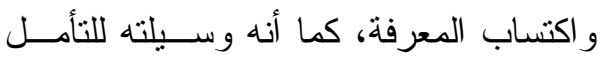

و التفكير وتحقيق التقدم فى جميــع مجــالات

الحياة، ولكى يتمكن الفرد من استخدام عقلـــه
مزيد من الدر اســات المتعلقــة بمتغيــرات الدر اسة الحالية، وصو لا إلى فهم أعمق لها. الأهمية التطبيقية: :ثانيا

يمكن الاستفادة من نتــائج الدراســـة

الحالية فى تعديل و إعادة صـــياغة المنـــاهج

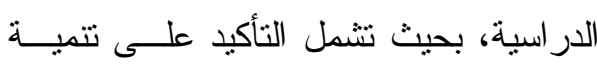
العادات العقلية و الذكاء الوجدانى.

تقدم الدراسة الحالية نتــائج متعلقـة

بالعلاقة بين عادات العقل و الأكاء الروحسى و الدافعية للتعلم، مما يسهر فى زيادة الـــوعى

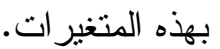

ومن الممكن أن نشجع الدر اسة الحالية

على إعداد وتصميم بر امج تدريبيـــة لتتميــة الدافعية للتعلم اعتمادا على العادات العقليــة و الأكاء الروحى.

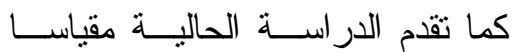

للافعية للتعلم، يمكن الاســـفادة منـــه فــى الدر اسات الخاصة بهذا المجال.

مصطلحات الدراسة:

عادات العقل : Habits of mind

Costa (2000:34) يعرف كل من

\&Kallick عادات العقل بأنها "القدرة علــى التتبؤ من خلال التلميحات السياقية بالوقــت المناسب لاستخدام النمط الأفضل و الأكفأ من

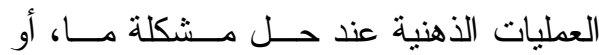
مو اجهة خبرة جديدة، وتقييم الشخص لفاعلية استخدامه لهذا النمط من العمليــات الذهنيــة 
كما تعــرف عــادات العقـلـل بأنهــا

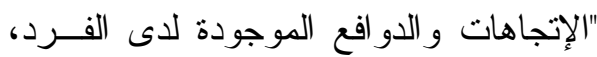

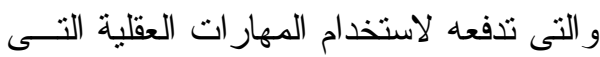

لديه بصورة مستمرة فى كل أنشطة حياتــه

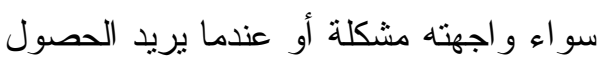

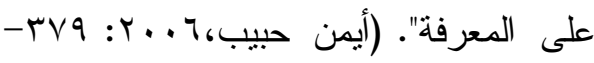

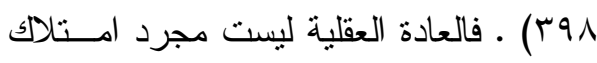

المعلومات بل هي معرفة كيفية اســتخدامها

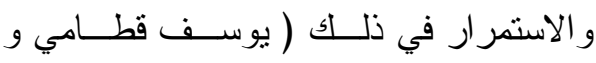

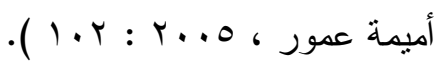

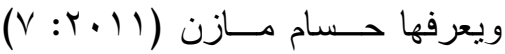

بأنها "إتجاه عقلى لاى الفرد يعطـى ســـة و اضحة لنمط سلوكياته، ويقوم هذا الإتجــاه على اســتخدام الفـرد للخبــرات الـــابقة والاستفادة منها للوصول إلى تحقيق الهـدف

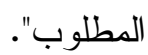

ومن خلال العرض الـسابق بمكـن

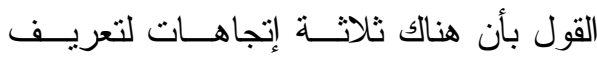

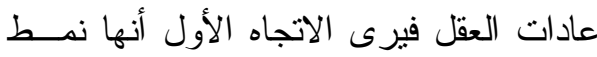

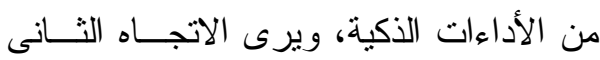
بأنها عبارة عن تفضيل إتجاهات عقلية معينة دون غيرها، بينما برى الإتجاه الثالث بأنهـا

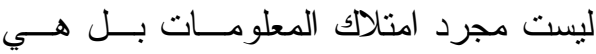
معرفة كيفية استخدامها والاستمر ار في ذلك (أى أنها تهنم بالكيف وليس الكم). وتعرف الباحثة عادات العقــل بأنهـــــا مجمو عة الأداءات الذكية المفضلة و المستمرة
الاستخدام الأمنل فان عليه اكتشاف عاداتــهـ العقلية و العمل على تتميتها.

وتعـــرف العــادات العقليـــة بأنهــــا

"مجموعة الاختيار ات حول نمط من العمليات العقلية التي يستخدمها الفرد في موقف معين،

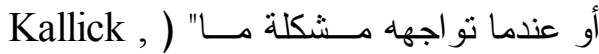
.(Costa \& 2000: 7

ويرى روبرت مارز انو ( .... ج: 9)

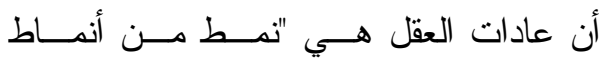
السلوكيات الذكية التي تقود المتعلم إلى إنتاج

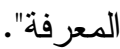

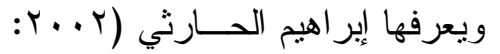

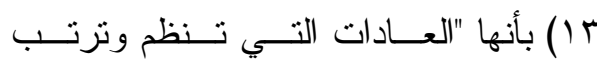
العمليات العقلية وتصنع الأولويات لتــصحيح مسار الفرد عند حل المشكلة".

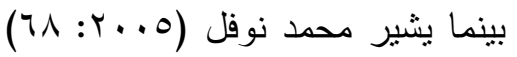

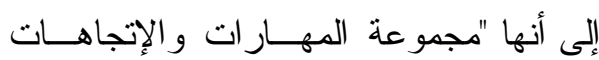
التى تمكن الفرد مــن تفـــيل أو اختيــار مجموعة من الأداءات أو السلوكيات الذكيــة

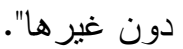

ويمكن تعريفها بأنها "موقـــ يتخــــه

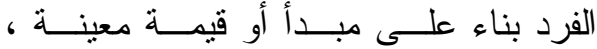

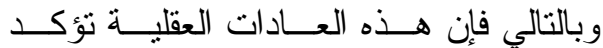
الأسلوب الذي ينتج به كل فرد معارفه مــن

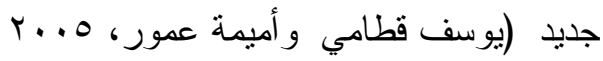


و اعمل مع الجماعة، و التجديد (فى: عو اطف

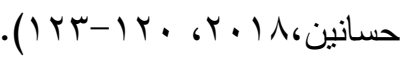

بينما صنفهاJaisle(2000 إلى عشر

عادات هى: الاهتمام العـاطفى - وضــوح

المفاهيم- التعلم المستمر - الحوار التأملى - لهنى

التفكير المكمل- الرؤية المتـــلة- العمـلـل

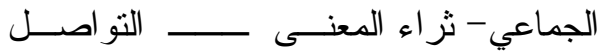

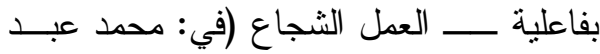

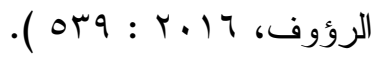

Costa \&Kallick (2000:21-أهــا

( 39 فقد عرض عادات العقل مــن خــلال

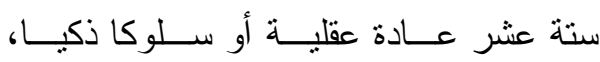

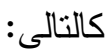

• المثابرة Persisting: وتعنــي إصـــرار الفرد على بذل أقصى جهده لأداء وتتفيذ المهام المطلوبة دون الاستسلام للعقبات.

Managing

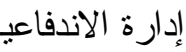

Impulsivity

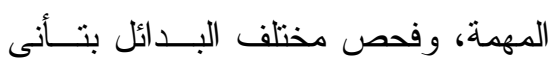

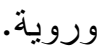

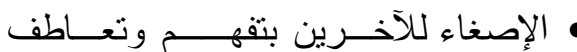
Listening to others with :understanding and Empathy تعني قدرة الفرد على حسـس الاســتماع

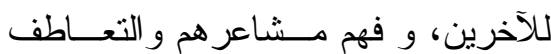

و المتكررة لاى الفرد و التى يـستخدمها فـى جميع مو اقف حياته. تصنيف عادات العقل: لقد تتاول الباحثُن عادات العقل مـن خلال توجهات نظرية مختلفة ومتعددة : فلقد تتاولها (Marzano,1998) من خلال أربعة

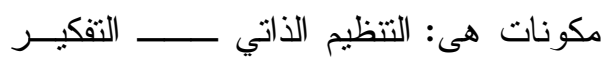

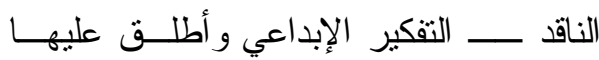

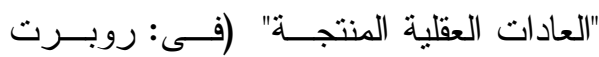

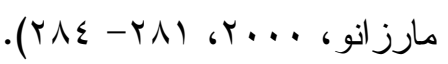
كما صــنفها ( Hyerle,1999:432) إلى ثلاث عادات رئيسة يتفر ع من كل منهــا عادات عقلية فرعية وتتتمتل العــادة العقليــة الأولى فى: خر ائط التفكير ، التى يتفرع منها عادات: طرح الأسئلة، وما وراء المعرفــة، و الحو اس المتعــددة و المهـــار ات العاطفيـــة. وتمنلت العادة العقلية الثانية فـى العــصف

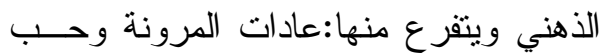
الاستطلاع وتوسيع الخبرة. أما العادة العقلية الثالثة فهى المنظمات و الرسوم ويتقرع منها عادات: المثابرة و التتظيم و الضبط و الدقة. وقسمها (2000) Covey إلى ســبع عادات هى: كن مبادر ا وسباقا، و ابدأ و عبنك

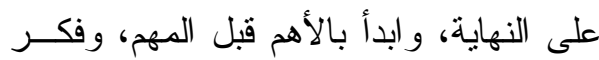
فى المصلحة المـشتركة للطــــفين، وتفهــ

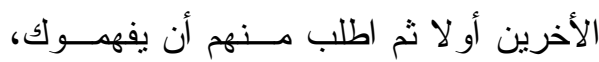




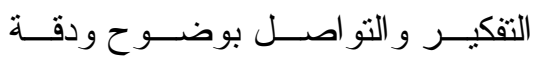

Thinking and Communicating :with Clarity and precision ويتضمن قدرة الفرد على التعبيــر بدقـــة عن أفكاره وتعزيزها للوصول إلى تفكير فعال، و اتخاذ قر ارات أكثر شمولية. • جمع البيانات باستخدام جميع الحــــ اس Gathering Data through All Senses البيئة المحيطة باستخدام جميع الحــو اس،

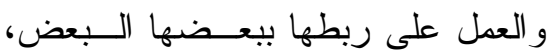
وتتكيل أفكار ناتجة عنها.

Creating, التصور و التخيل و الابتكار Imagining, and innovating قدرة الفرد على الوصـــول إلـى حلـــول جديدة وغير تقليديـة للمـشكلات التـى لـى تو اجهه، و العمل على إيجاد حلول جديدة مبتكرة للمشكلات.

• Responding With الـشنغ للــتعلم Wonderment

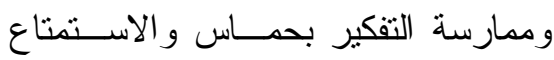
بالتعلم ومو اصلة التعلم مدى الحياة.

• الأقدام على المخاطر المسئولة Taking Responsible Risks وجود دافع قــوى إيوجــهـ الفــرد إلــى الانطلاق لاكتشاف الغموض مع نقــدير
التفكير بمرونة:Thinking Flexibility تعني قدرة الفرد على تغيير زاوية تفكيره

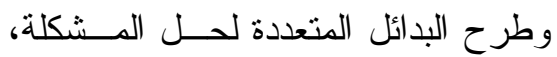

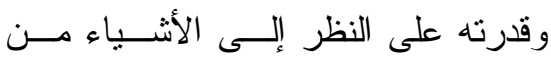

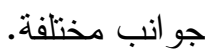
• التفكير في التفكير (مـــا ور اء المعرفــة) Thinking About our Thinking ) Metacognition على التفكير فيما يفكر فيه، وقدرته على تقييم تقكير ه.

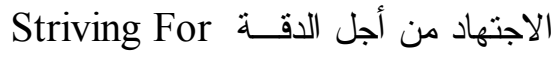
Accuracy and Precision قدرة الفرد على التفكير جيدا قبل الكلام،

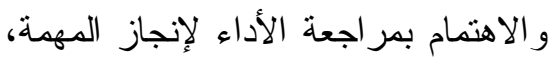

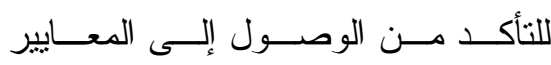

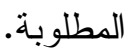

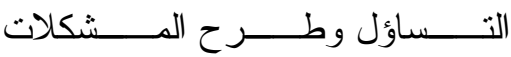
Questioning and Posing Problems طر ح التساؤلات ومحاولة البحــث عـن ولن

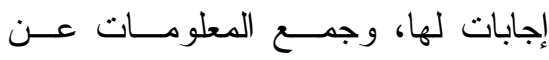
المشكلات و العمل على حلها. • تطبيق المعارف الماضية على المواقــف Applying Past Knowledge الجديدة to New Situations الخبرة السابقة للاستفادة منها فى مو اجهة المو اقف الجديدة. 
من العمليات الذهنية التى تمكن الفــرد مــن تطوير نتاجه الفكرى، وتصبح عادات عقلية يستخدمها فى شتى مناحى حياتـــه العلميــة

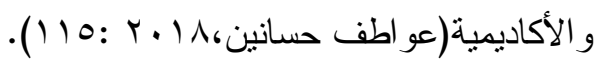
إن عادات العقل تجعل المتعلم ينطلق نحو عالم أرحب، فعادات العقل وتعلمها لــــ فو ائد جمة يمكن إجمالها فيما يلــي(محمــود الطنطاوى، VI • r: r • (1):

- الثمولية: تعطي عادات العقل للثخص

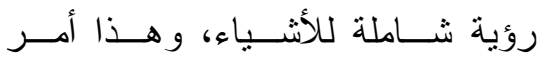

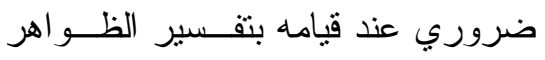
على نحو علمي، وأمر ضروري حسين بندين يتخذ قرار ا ما وحين يحل مشكلة معينة. - تدعيم التفكير النقدي: فعادات العقل هي سلوك فكري يدعم التفكير النقدي. - تتشط العقل: لأن عادات العقـلـل تجعـل العقل فعالا وتصرفه عن الخمول. - تقوية الروابط الاجتماعية: فهـي تتقـلـل

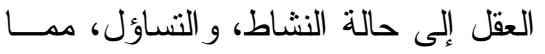
يدفعه إلــى المـشـاركة فــي الأعمــال

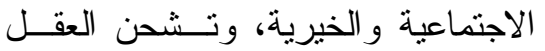
بروح نقدية فاعلة فــي ميــدان العهـلـل

$$
\text { و الإنتاج و الإبداع. }
$$

- الحيوية و الاستمتاع: لأنها تجعل العقـلـل

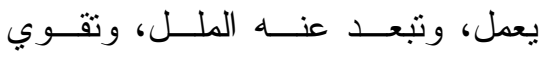

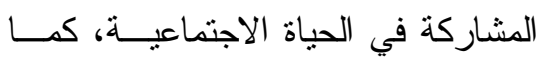

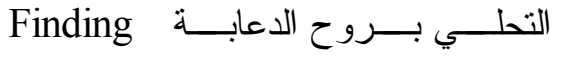
Humor

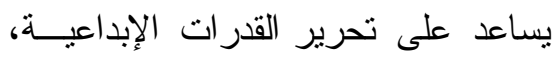
و التخلص من التونز.

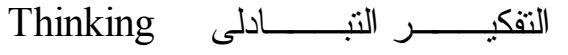
interdependently على الانسجام فى التفكير مـع الآخــرين و العمل ضمن مجموعات.

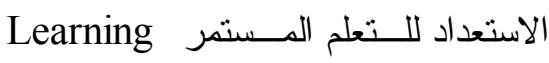
Continuously

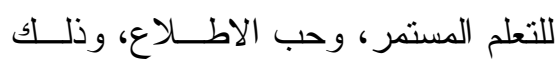

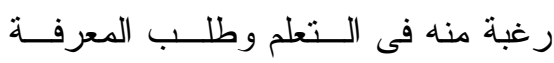

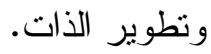

وسوف تعتمد الدراسة الحالية علـى تصنيف Costa\& Kallick الــنى يعتبــر الأحدث و الأكثر تحديدا وشـمولية لعـادات العقل المختلفة. أهمية عــادات العقـل: لعادات العقل أهمية كبيرة، لأنها تتيح للفرد اكتساب مجموعة من العادات العقليــة التى تفتح آفاقا جديدة للعقل البشرى، وتجعله يصل به إلى أفضل أداء. ولقد بدأ الاهتمام فى الإتجاه المعرفى

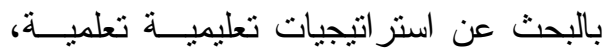

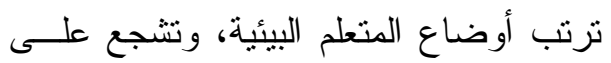

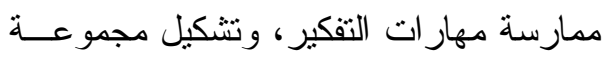


ويعتبر الــذكاء الروحـى المحــرك

الرئيس للإنسان، فهو الذى يوجهه نحو فعل

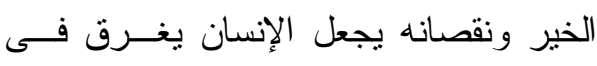

إثباع حاجاته المادية (بشرى أحمد، V . . Y.

צr (1) بأنه

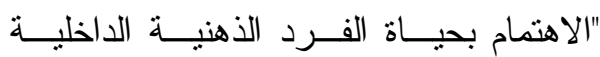

$$
\text { وبمز اجه". - ولهام }
$$

فالمقصود بالذكاء الروحى "أن يعسى

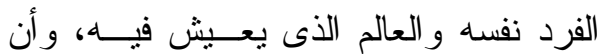
يتعمق فى نوعية مشاعره، ويدرك العلاقات التى تربط بين الظو اهر المحيطة به" (تــونى

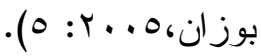

Amram (2007:

$$
\text { ويعرفه (2) }
$$

"القدرة على تطبيــق المــصادر و الــصفات الروحية لتعزيز الأداء وتحقيق السعادة."

ويشير Sisk (2008:25 إلى أنـــه

يتمنل فى "القدرة على استخدام مــــهج قـائم على الحس والتأمل و التصور للوصول إلى لى لـ المعرفة الداخلية لحل المشكلات".

Amram \& Dryer ( ويرى كل من

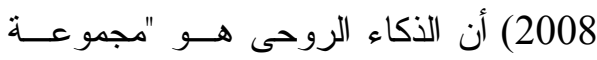
القدر ات التى يستخدمها الناس لتطبيق القـيم

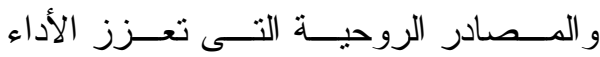

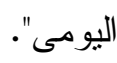

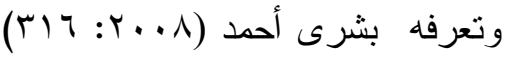

بأنه "القدرة على التصرف بعاطفة وحكمــة
تشعر الثخص بأنه منتج وفاعل، وهـــا يقوي الثعور بالحيوية و الاستمتاع. ويؤكد روبرت مارزانو ( . .. ج: 9) أن المستوى الضعيف لعادات العقل يــؤدى إلى تعلم ضعيف، بغض النظر عن مسنوى

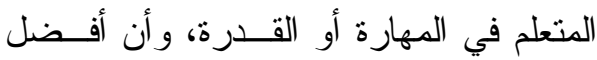
الطرق الني يمكن أن يستخدمها المتعلم فـي ولي وني

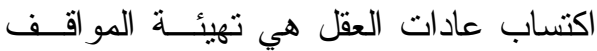
والأنشطة التعليمية التي تتطلب منه ممارسة مهار ات التفكيــر المختلفـــة للتوصــل إلــى المعلومات الجديدة التي يمكن توظيفها فـي المو اقف و المشكلات الحياتية و الأكاديميــة، ويرى كذللك أن عادات العقل هي نمط مــن أنماط السلوكيات الذكية التي تقود المتعلم إلى

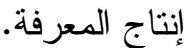

Spiritual

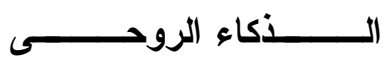

\section{:Intelligence}

تعد النو احى الروحية علـى درجــة

كبيرة من الأهمية فى حياة الإنسان، لأن تلك لكانك

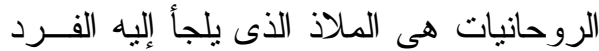

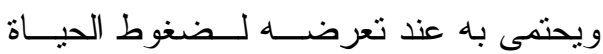
وصر اعاتها، فما أحوجنا إلى الاهنمام بعودة الإنسان إلـى إنــسانيته وخيريتـــه ونقائـــه الروحى، وبخاصة فى هذه الأيام التى انشغل

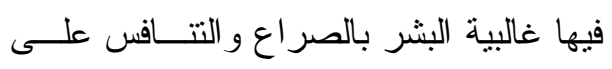

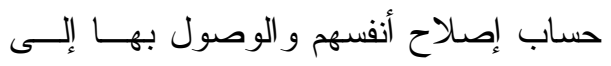

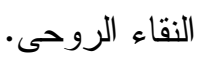


ويــــ George (2006:23) أن

أهمية الذكاء الروحى تتمنل فى إسهامه فــى

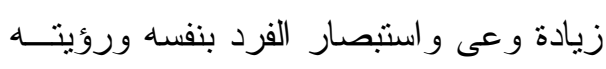

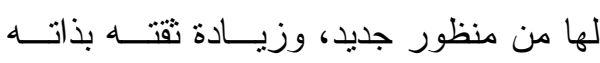
وبالآخرين، وتقليل ضغطه وتوتره

ولقد أثنارت منظمة الصحة العالميــة

أن إثباع الحاجات الروحية تــساعد الفــرد

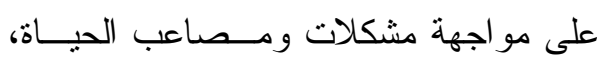

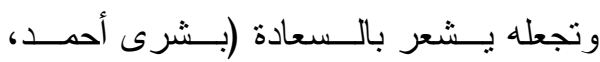

. (r) V: Y.. A

إن مردود الأكاء الروحى على سلوكنا

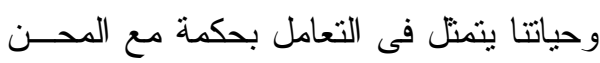

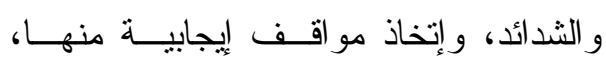

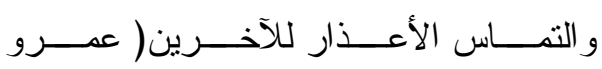

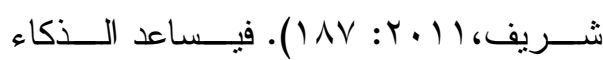

الروحى الفرد على التوجه لعبادة الله سبحانه

وتعالى بــصدق ويقـين، ويجعلـــه يلتــزمز

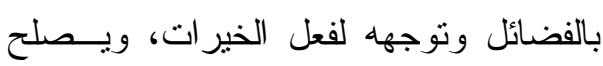

النفس البشرية من النزعات السلبية، أى أنسـه

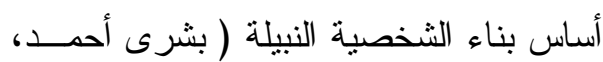

.

و أخير ا، فإن الذكاء الروحي يجعلنا أقل

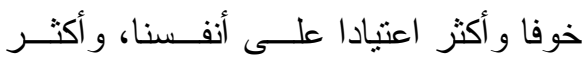

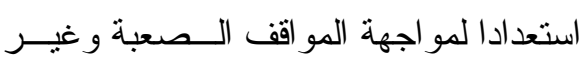

المريحة،كما يعطينا القــدرة علـــى التمييــز

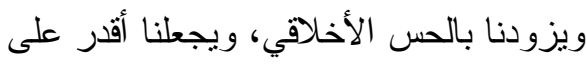

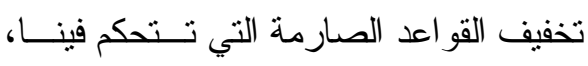

أثثاء محاولة تحقيق الاتزان (السلام الداخلى

$$
\text { و الخارجى)". }
$$

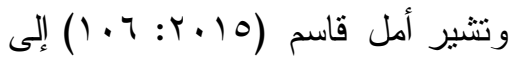

أنه "مجموعة القدرات الفطرية التى يمكن أن

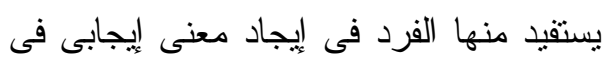

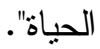

بينما يرى أحمد محمد (10 • Y: 9 10)

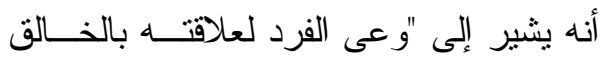

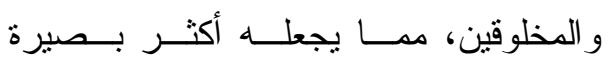

بالمعتقدات الدينية و الظواهر الروحية وقادرا

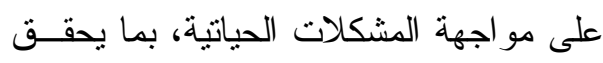

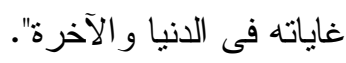

وتعرف الباحثة الذكاء الروحى بأنــهـ

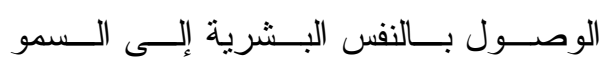

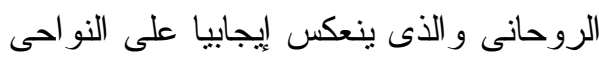

السلوكية و الأخلاقية، ويؤدى إلــى تحقيــق

الرضا و السعادة و السلام الداخلى.

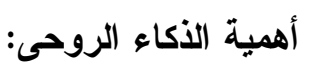

أن الذكاء الروحى بكل ما بحمله مـنـ

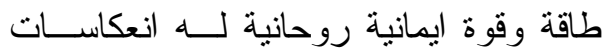

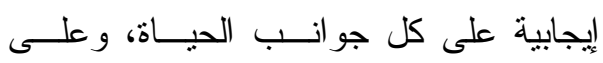

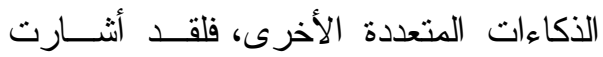

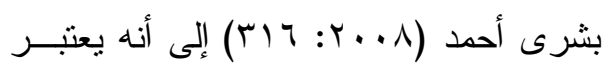

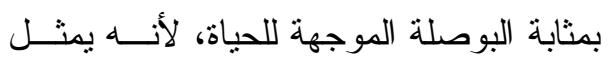

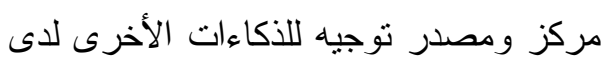
الإنسان. 
‘Personal Meaning Production

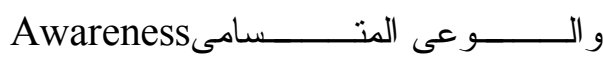
Transcendental

الممند Conscious State Expansion.

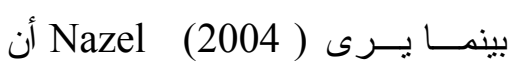

مكوناته هــى الحــب و اللطــــ و الــصدق و الصبر و التـسامح و التــوازن أو الـسـلام

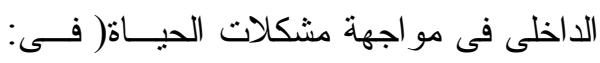

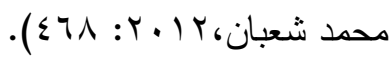

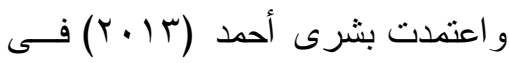

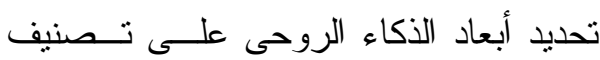
Amram \& Dryer الروحى إلى خمسة مكونات هى:

- الوعى: ويعكس هذا البعد القدرة علـى بـى

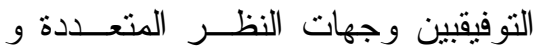
إثارة الوعى أو تعديله ، كمحاولة لزيادة

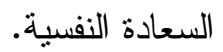
- النعمة: يعكس هذا البعد التبصر و السلام الداخلى و التبصر ، وحب الحياة اعتمـــادا

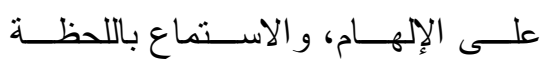

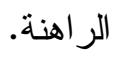
- المعنى: يعكس هذا البعد القــدرة علــى تكوين تفسير ات و الاحساس بالمعنى. - التسامى : يعكس هذا البعد قــدرة الفــرد

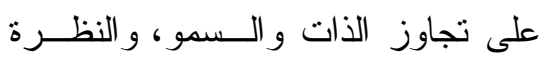
الكلية.
ليغلب علينـــا مفــاهيم التفــاهم و التعــاطف

و الرحمة.) (Selman et al., 2005: 25)

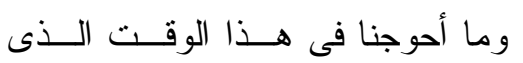

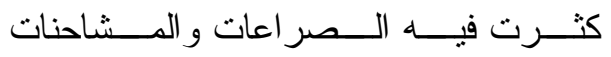

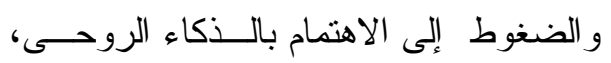

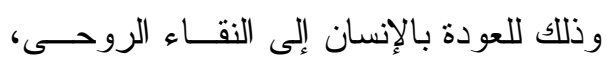

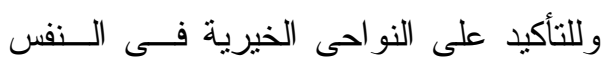

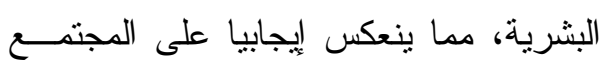
ككل. - مل

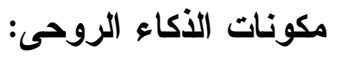
بـرى Emmons (57: 2000) الذكاء الروحى يتكون من عدة قدرات نوجد

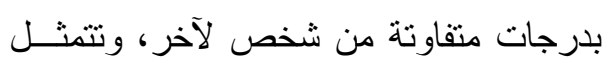

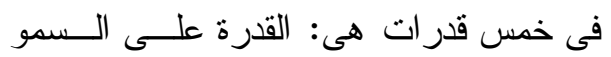

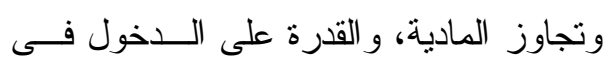

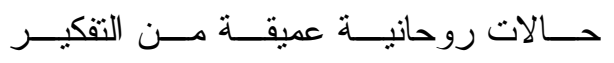

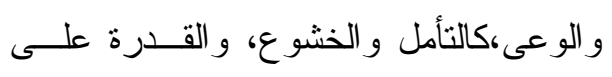
توظيف المصادر والإمكانات الروحية فـى ولى ولى ولى

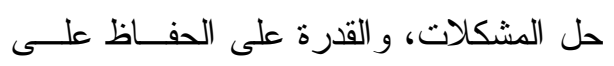

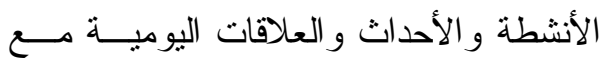
الآخرين، و القدرة على الاستقامة و الــصلاح و التحلى بالسلوك الفاضل. ويشير (2000:54) King إلى وجود أربعة مكونات للذكاء الروحى هى: التقكيـــر

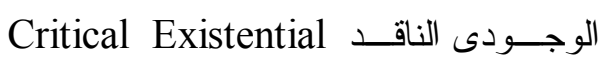
Thinking و الإنتاج الثخصى ذو لنو المعنـى 


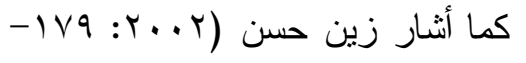

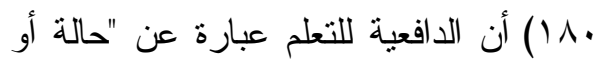
طاقة داخلية عند المتعلم تدفعه إلــى الانتبـــاه للموقف التعليمى و الإقبال عليه بنشاط موجه

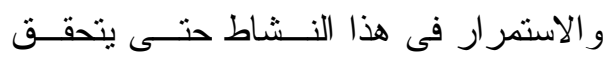

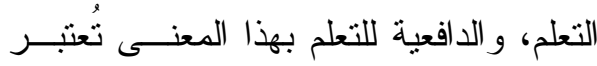

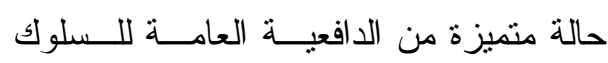
الإنسانى".

وهى "حالة داخلية لاي المتعلم تحرك

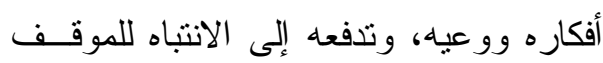

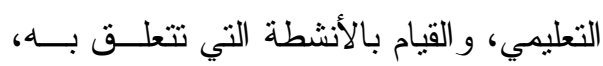

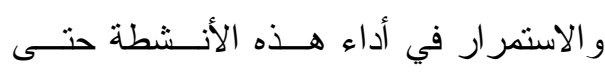
يتحقق التعلم كهدف المتعلم" (محى الدين توق

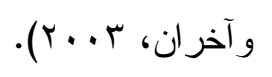

ويُوضح أحمد عبد الرحمن وعـزت

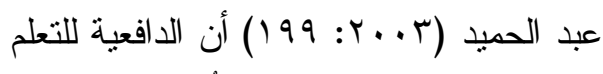
"حالة داخلية تَستثير المتعلم وتُوجهه إلــى أن أن

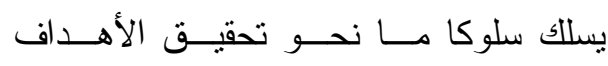
التعليمية".

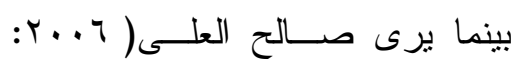

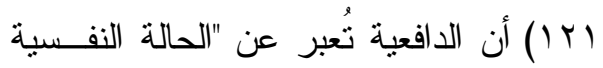

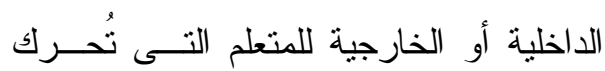
سلوكه وتوجهه نحو تحقيق غرض معسين،

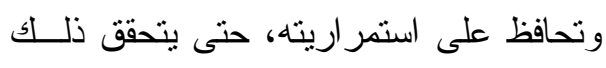

- الحقيقة: يعكس هذا البعد قــــرة الفــرد

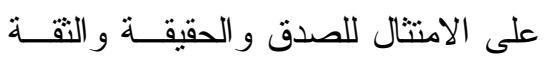
و التو اضع، و إظهار المحبة و السلام.

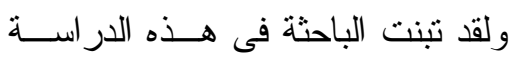

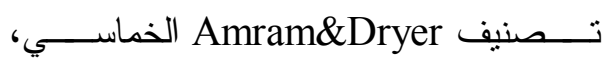

$$
\text { لشموله ووضوح أبعاده. }
$$

\section{الدافعية للتعلم Learning Motivation:}

تُعتبر الدافعية من أهـــم موضــــوعات

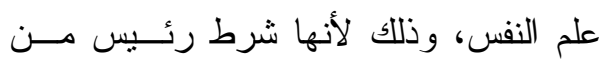

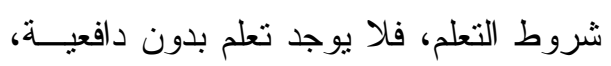

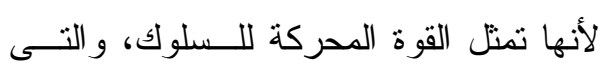
تزود الفرد بالطاقة والنشاط اللازمين لتحقيق أهد افه.

ولقد تعددت تعريفات الدافعية للــتعلم،

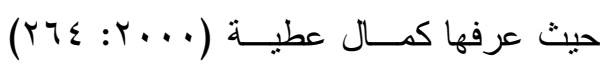

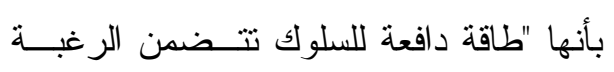

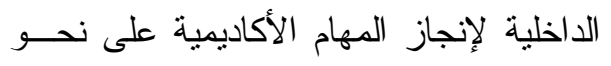

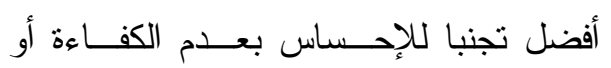

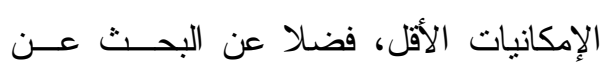
الإثارة التعليمية".

ويـذكر (350 : 2000) \&

أنها "نز عة داخلية تحدد ســلـوكيات Wilson

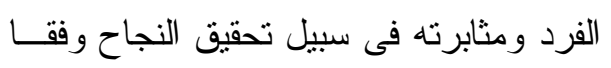

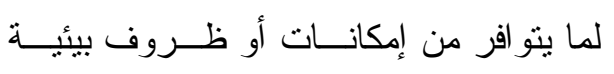
محيطة، كما تُعرف بأنها قرار ات فردية تــنتم داخليا بهدف إنجاز مهمة أو عمل". 
ويتضح من خلال العــرض الــسابق

وجود وجهتى نظر لمفهوم الدافعيــة، حيــث

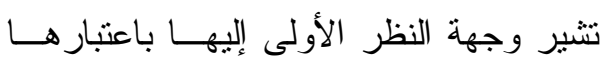

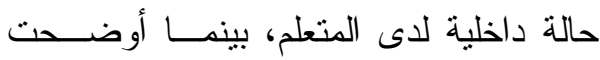

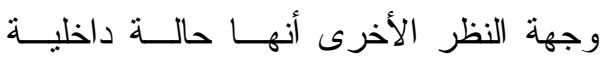
وخارجية لدى المتعلم، و أجمعت التعريفـات التهات

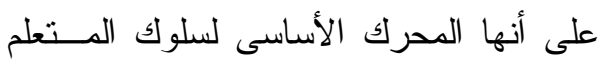

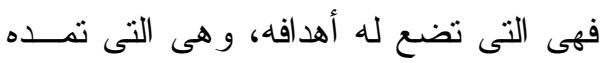
بالطاقة التى تمكنه من بذل الجهذ و اســتخلال

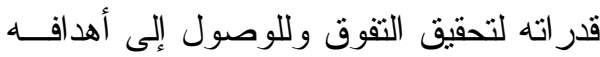

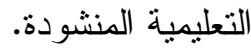
تصنيف الدافعية:

لقد صنف بعض العلماء الدافعية إلـى الدافعية الداخلية Intrinsic مقابــلـ الدافعيـــة الخارجية Extrinsic (عادل محمد، r ...r: س أولا: الدافعية الداخلية: ويكون مصدر ها المتعلم نفسه، حيــث

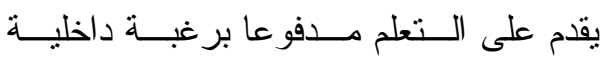

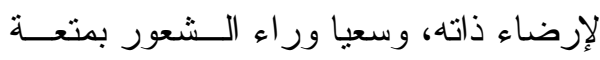

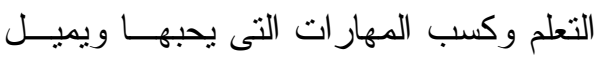

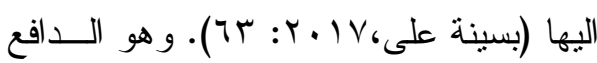

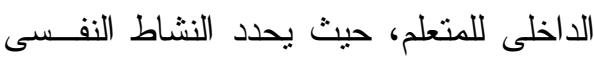
الذى بدفع المتعلم أن يقبل على التعلم بمبادرة

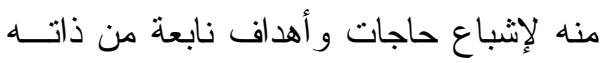

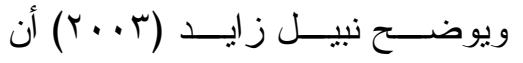

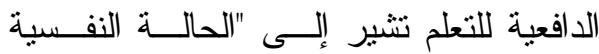

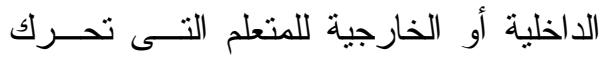
سلوكه وتوجهه نحو تحقيق غـرض معـين وتحافظ على استمر اريته حتى يتحقق الهدف ونستثار هده القوة المحركة بعو امل نتبع من لن

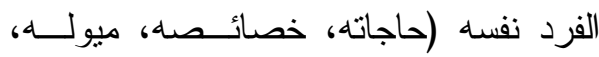

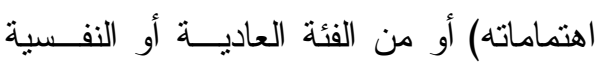

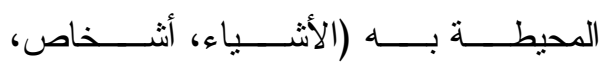
الموضو عات، الأفكار)". وتثير الدافعية للتعلم إلى "الطاقة التي

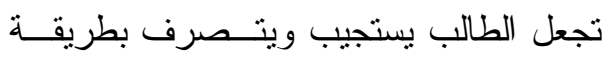

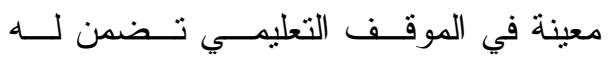
الحصول على الثواب بشكل مادي أو معنوي

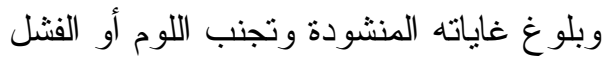

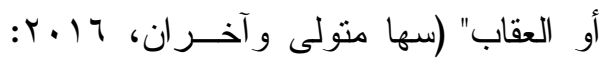
$\cdot(\vee \cdot$

وتُعرف من الناحية الــسلوكية بأنهـــا

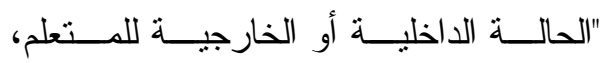
التى تحرك سلوكه وتعمل علــى اســتمر اره

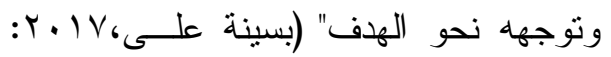

تعرفها الباحثة بأنها "الطاقة الداخليــة

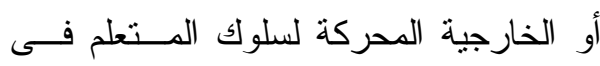

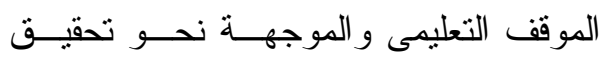
أهدافه التعليمية". 
و الأنشطة المحكومة بدو افع داخليــة تعــزز

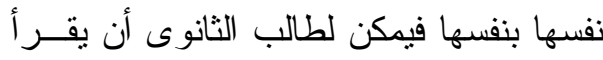
كل ما يقع تحت يديه عن رياضته المفـــلة لفئل

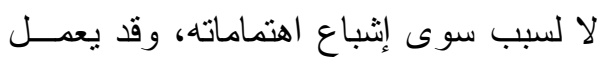

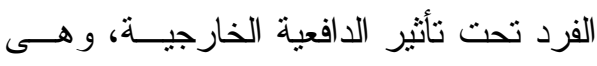

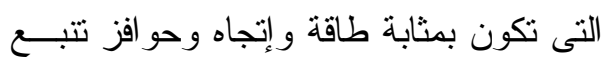
من الرغبة لنرك انطباع حسن لدى الآخرين

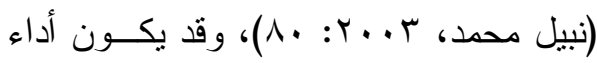
العمل من أجل الحصول على جائزة ولــيس

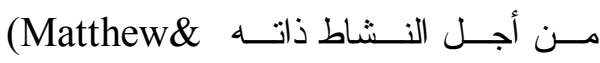
.Nicole, 2002: 254) ومن خلال ما سبق نستطيع القول بأن

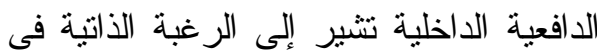

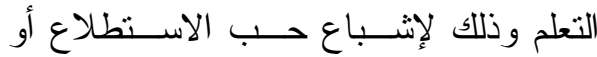

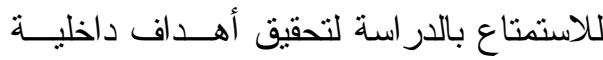

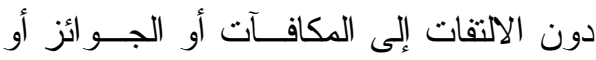
الإثابة الخارجية، أى أنها نُشير إلى التعلم من

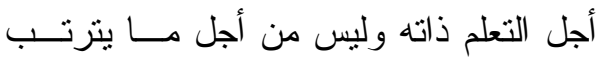

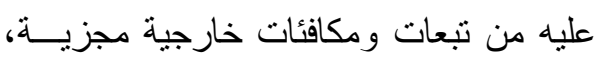
بينما نشير الدافعية الخارجية إلى الرغبة في ونى

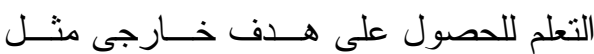

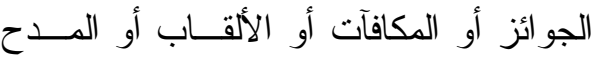

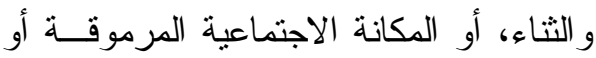

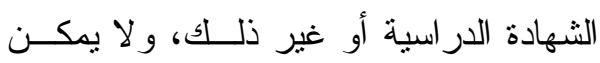
التقليل من أهمية الدافعية الخارجية مقارنـــة بالدافعية الداخلية فكلاهما له دوره الفاعل فى اهيه سلوك الفرد و لا يمكن المفاضلة بينهما.
فيبذل جها نحو تحقيقها (هبة محمد، 17 .$(:) \mathrm{V}$ وتعنى الدافعية الداخلية قــدرة الفــــد على تحديد ميولـــه ور غباتـــه و اهتماماتــه، و العمل على إثباع حاجاته دون وجود قوى

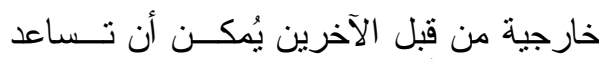

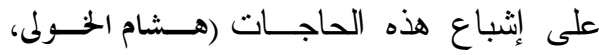

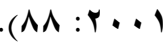

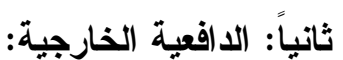
هى التى يكون مــصدرها خارجيــا

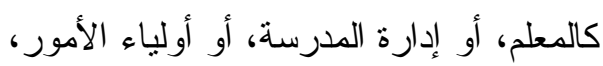

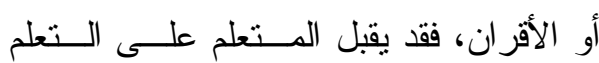
ارضــــاء للمعلمـــين أو الو الـــدين أو إدارة المدرسة وكسب حبهم وتشجيعهم وتقـدير هم لإنجاز اته أو الحصول على تشجيع مادى أو

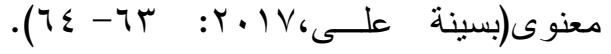

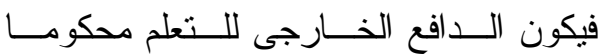
بمصادر خارجية منل الحصول على درجـة أو رضى الوالدين أو المعلم، ويكون مرهون بالعو امـــلـ و الظــــروف الخارجيــــة(هبــــة

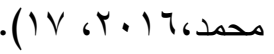
ولا يجب علينا المفاضلة بين الدافعية الداخلية و الخارجية، فقد يعمل الطلاب فـى ئى بعض الأحيان بتأثثر الدافعية الداخلية، بمعنى

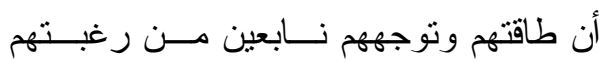
الذاتية فى المـشاركة فـى نــشاط معـين، 
و المثابرة لدى المتعلم، مما يؤدى إلى تحسن

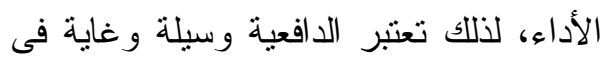

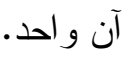

فروض الدراسة:

فى ضو هء مــشكلة الدر اســـة الحاليــة

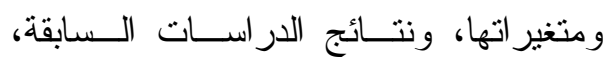
تــم صـــاغة فــروض الدر اســـة الحاليـــة كالتالى:

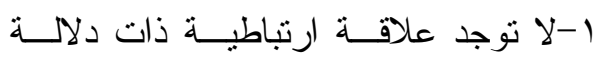

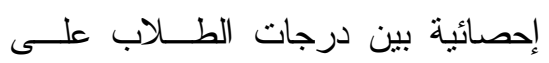

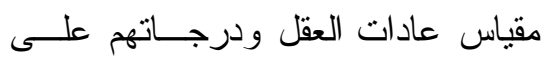
مقياس الأكاء الروحى.

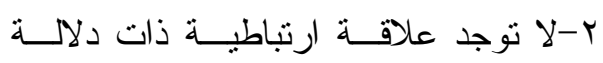

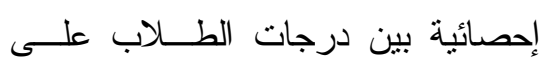

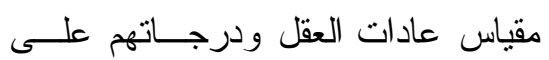
مقياس الدافعية للتعلم.

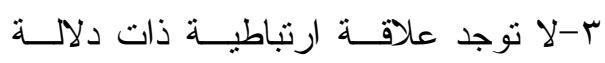

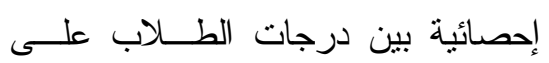

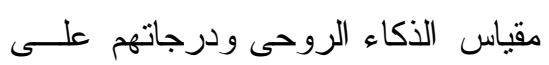
مقياس الدافعية للتعلم.

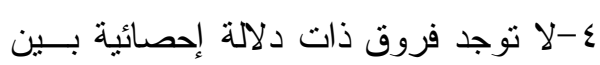

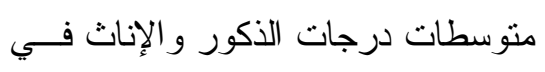

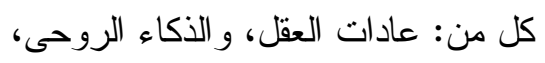
ودافعية التعلم لدى طلاب كلية التربيـــة

$$
\text { بسو هاج. }
$$

ه-لا يمكن يمكن التنبؤ بالدافعية للتعلم مــن بـن

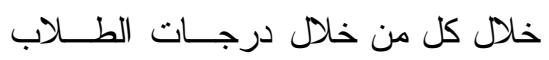

وظائف الدافعية للتعلم وأهميتها:

للافعيـــة وظــائف عـــدة منهـــــا (بــسينة

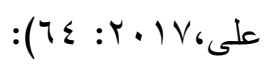

- التششيط: إذ يعمل الدافع علـى تــــيط

الفرد للتفاعل مع موقف معـين و القبــام

$$
\text { بسلوك معين. }
$$

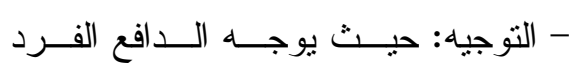

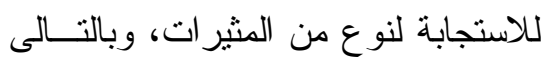
توجيه السلوك نحو الهدف.

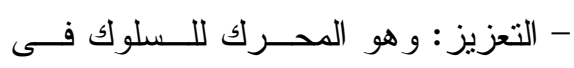
إثباع الرغبات.

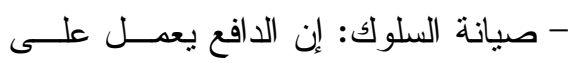
استمرار السلوك من أجل تحقيق التعلم.

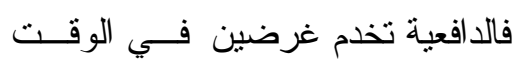

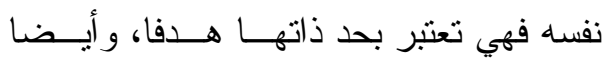
وسيلة لتحقيق أهداف أخرى، لذلك تصبح من دانه

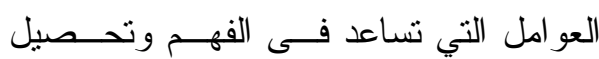

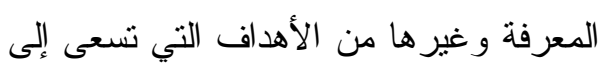
تحقبقها، فــالطلاب الــذين لــديهم الدافعيـــة

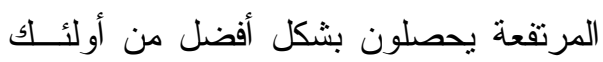
الذين لديهم دافعية منخفضة (رجاء أبو علام،

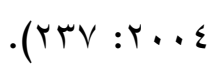
وللإنك فان تحسين دافعيــة الطــلاب

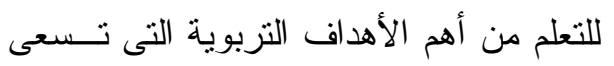

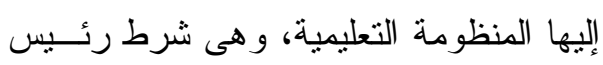

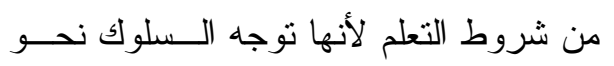
أهداف معينة، وتعمل علــى زيــادة الطاقـــة 


$$
\begin{aligned}
& \text { درجات هذه العينة فــي اســتخلاص نتــائج }
\end{aligned}
$$

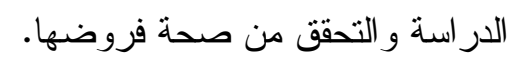

$$
\begin{aligned}
& \text { ثالثا : أدوات الدراستــــة }
\end{aligned}
$$

تكونت أدوات الدر اسة الحالية من:

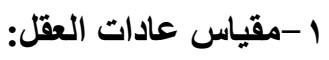

أعد هذا المقياس عبد العزيز الثخص عادل

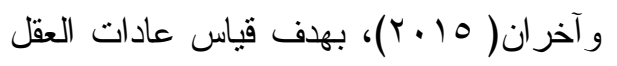

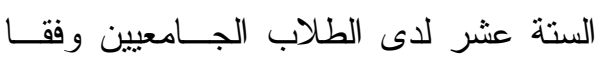

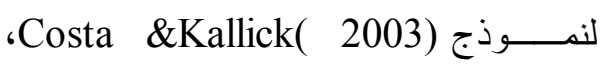

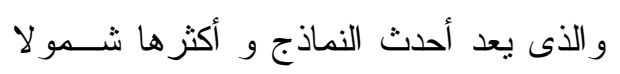

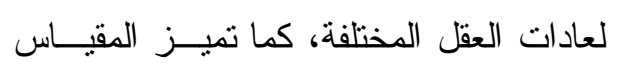

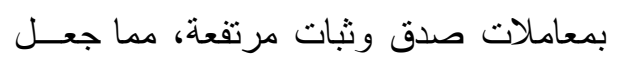

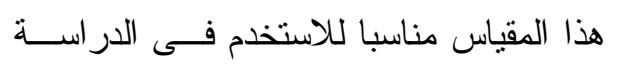

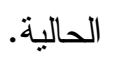

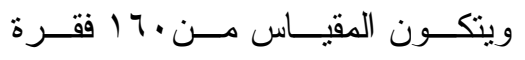

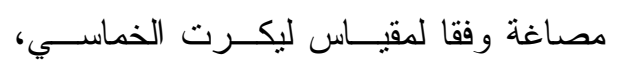

تتتاول عادات العقل لدى الطلاب الجامعيين،

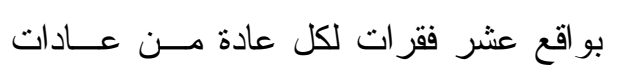

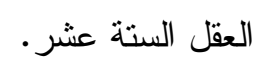

ويتم تصحيح المقياس وفقا لميز ان ذو

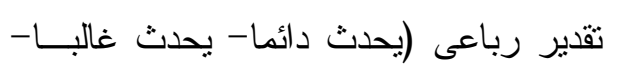

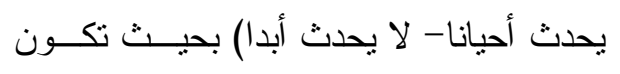

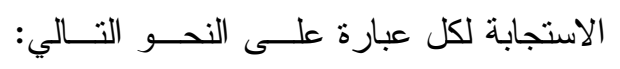

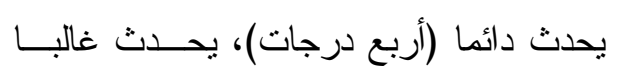

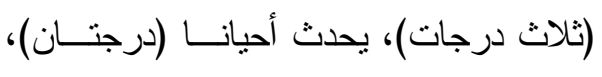

$$
\text { ولا يحدث أبدا (درجة واحدة). }
$$

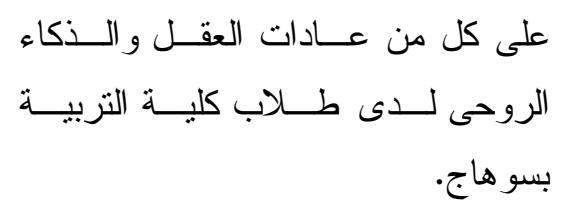

منهج الدراسة وإجراءاتها:

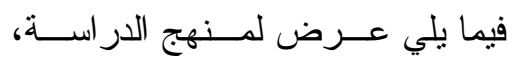

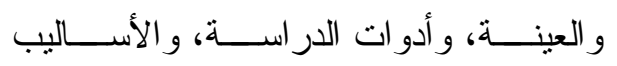

الاحصائية، و إجر اءات الدر اسة: ولات

أولا: منهج الاراسة:

استخدمت الباحثة فى الدراسة الحالية

المنهج الوصفى الارنباطى لدراسة العلاقات

المتبادلة بين المتغير ات المختلفة وتقسير ها.

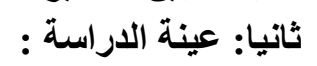

أ-عينة حساب الخصائص السيكومترية:

اختيرت العينة الاستطلاعية بطريقــة

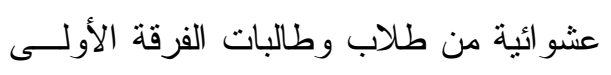

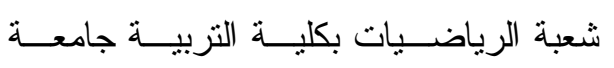

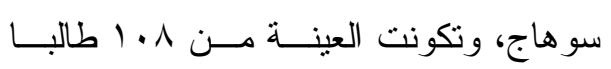

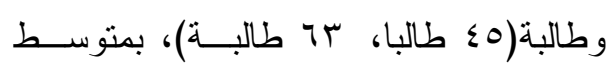

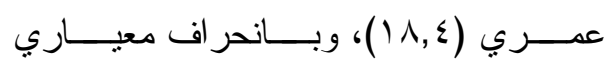

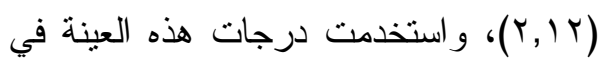

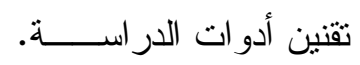

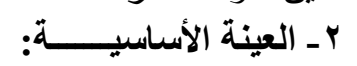

تكونت عينة الدر اسة الأساســية مـنـ الاسلة

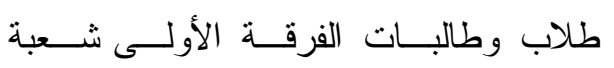

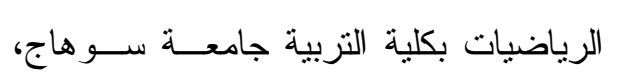

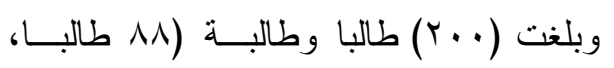

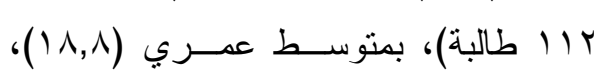

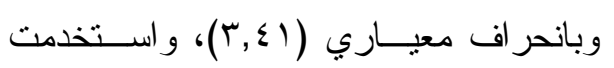


قام الباحثون بحساب ثبـــات المقيـــاس

الخصائص السيكومترية للمقياس:

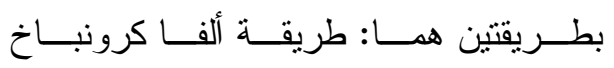

صدق المقياس:

وتز اوحت قيم معاملات الثبات لأبعاد المقياس

تحقق معدو المقيــاس مــن صــدقه

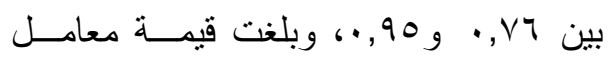

باستخدام صدق المحكمين، وصدق مفــردات

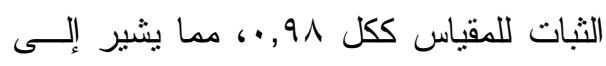

الاختبار ،وصدق المقارنة الطرفية، وأثنارت

ثبات المقياس.

كما تم اســتخدام طريقــة التجزئـــة النتائج إلى صدق المقياس.

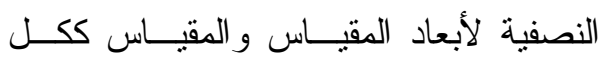

أما فى الدر اسة الحالية قامت الباحثــة

وتز اوحت قيم معاملات الثبات لأبعاد المقياس ولاس لابعاد

بحساب صدق هذا الاختبــار عـن طريــق

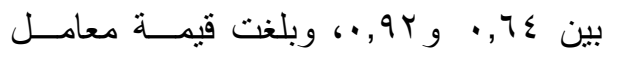

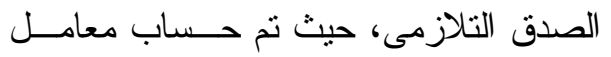

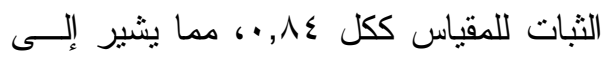

الارنباط بين الدرجات على المقياس الحــالى

و الدرجات على مقياس عادات العقل إعـــداد:

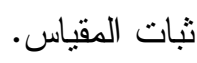

حازم سليمان وزياد جر اح (10 ب. (ب)، وبلغت

أما فى الدراسة الحالية قامت الباحثنــة

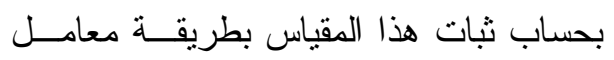

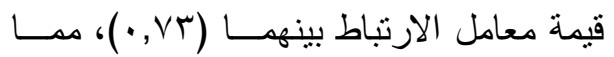

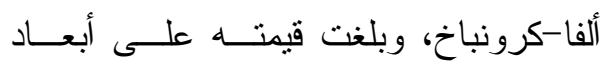

يشير إلى صدق المقياس.

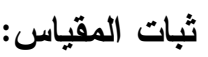

المقياس القيم الموضحة فى الجدول التالى:

جدول (1)

ثبات مقياس عادات العقل بطريقة معامل ألفا-كرونباخ

\begin{tabular}{|c|c|c|c|c|c|}
\hline ألفا-كرونباخ ثعل & 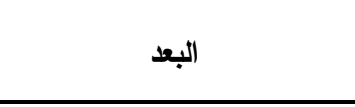 & b & ألفا-كرونباخ ثعات & 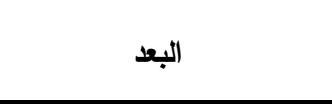 & م \\
\hline$\cdot, \vee \mathrm{T}$ & جمع البيانات باستخدام الحو اس & 1. & $\cdot, V 7$ & 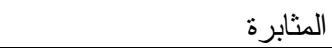 & 1 \\
\hline$\cdot, V \varepsilon$ & التصور و التخيل و الابتكار & 11 & $\cdot, V T$ & إدارة الدافعية & r \\
\hline$\cdot, \wedge$. & الثغف للتعلم & ir & 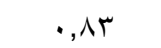 & الإصغاء بتفهم وتعاطف & r \\
\hline$\cdot, v r$ & الإقدام على المخاطر المسئولة & r & $\cdot, V 7$ & التقكير المرن & $\varepsilon$ \\
\hline$\cdot, V Y$ & التحلي بروح الدعابة & $1 \varepsilon$ & $\cdot, 7 \wedge$ & التفكير فى التفكير & 0 \\
\hline$\cdot, \wedge т$ & التفكير التبادلى & 10 & $\cdot, 77$ & الاجتهاد من أجل الدقة & 7 \\
\hline$\cdot, \mathrm{VV}$ & الاستعداد للتعلم المستمر & 17 & $\cdot, v_{0}$ & التساؤل وطر ح المشكلات & $\checkmark$ \\
\hline$\cdot, \wedge)$ & عادات العقل & 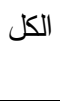 & $\cdot, \mathrm{TV}$ & تطبيق المعارف السابقة على & $\wedge$ \\
\hline & & & $\cdot,(v)$ & التفكير و التو اصل بوضو ح ودقة & 9 \\
\hline
\end{tabular}


مما يشبر إلى ثبات المقياس.

حساب الصدق العاملى، وقد نتج عن التحليل

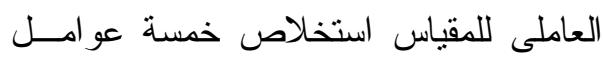

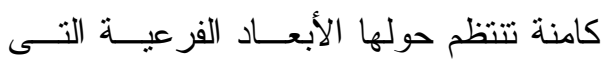
يتكون منها المقياس.

أما فى الدر اسة الحالية قامت الباحثتــة

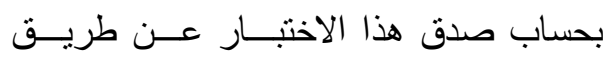

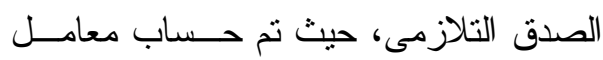

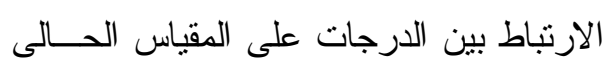

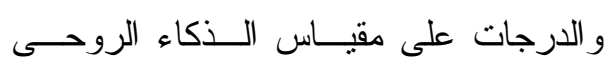

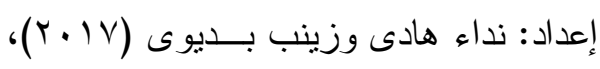

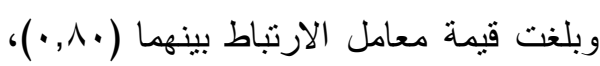
مما يثير إلى صدق المقياس. ثبات المقياس:

قــــام (Amram\& Dryer,2008)

بحساب ثبات المقياس عن طريــق معامــل

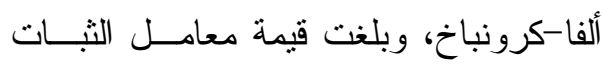

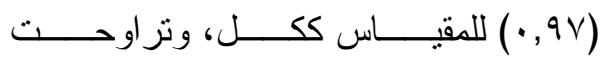

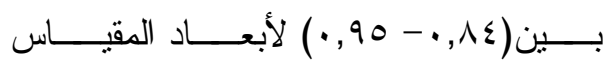

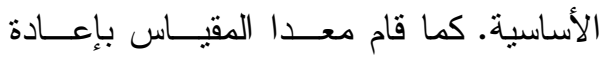

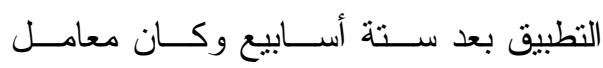

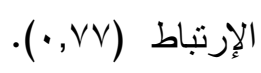

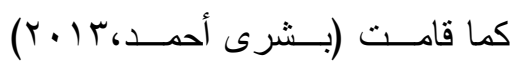

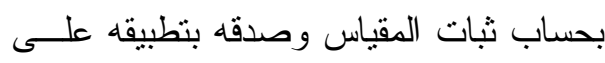
عينة مكونة من Vo من الـــكور والإنــات

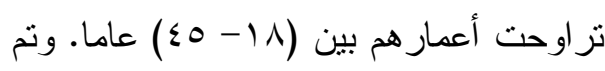

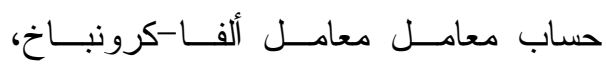

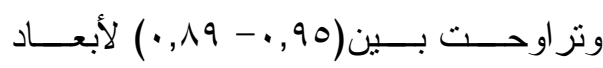

ثانيا: مقياس الأكاء الروحى:

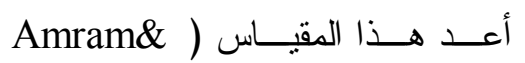

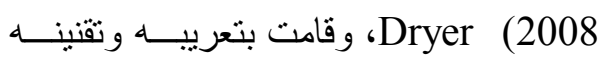

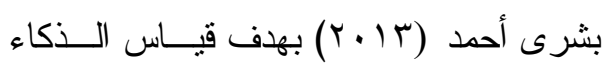
الروحى لدى الطلاب.

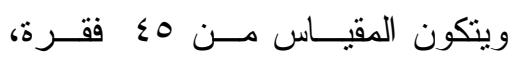

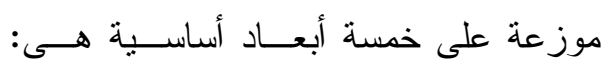

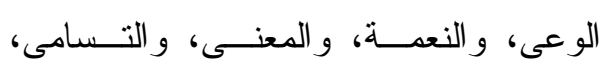

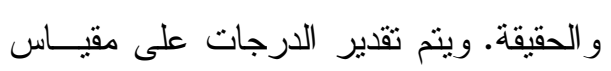
سداسي ( أبدا، نادر ا جدا، نادر ا إلى حد مــا،

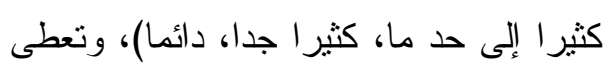

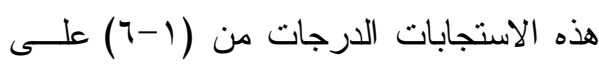
الترتيب. أما الفقر ات الــسالبة وعــدهدها 10

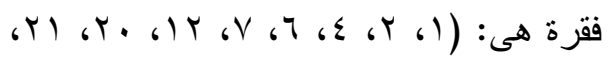

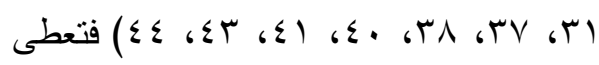
الدرجات من (0-1) على الترتيب. حساب الخصائص السيكومترية: صدق المقياس:

قـــام (Amram\& Dryer,2008)

بحساب الصدق التلازمى للمقياس مع قائمـــة

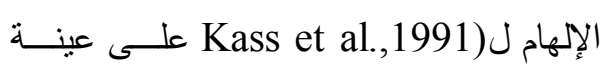
قو امها ع بr ، وكانت معاملات الارتباط بين

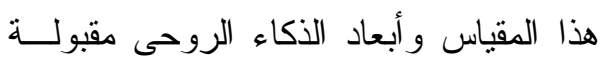
إحصائيا.

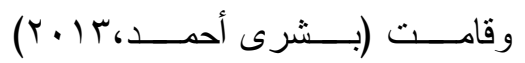
بالتحقق من صدق الاختبـار عـن طريــق 
المهام التى تتحدى قدر اته، واســتقلاليه

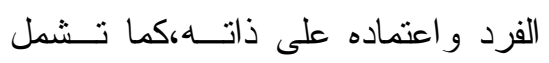

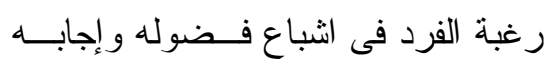

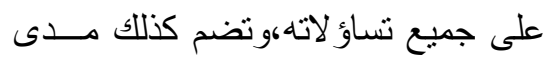

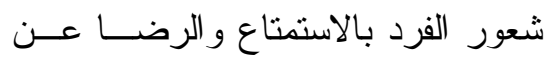

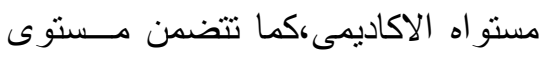

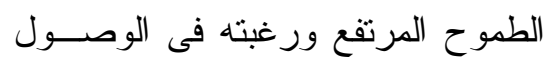
لغايات مرتفعة. - الدافعية الخارجية: وتشمل كل العوامـلــل

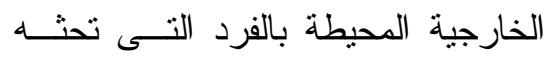
ونتجعاه على التعلم، ونتشل: الأســرة

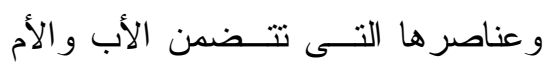
و الإخوة والأقارب، كما تشمل المدرسه

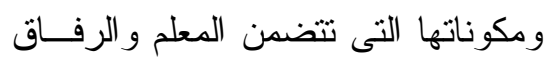
و الإدارة المدرسية و المقرر ات التعليمية.

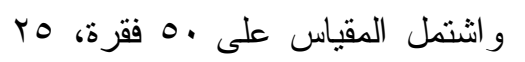
فقرة لقياس الدافعية الداخلية هى الفقرات من لهن

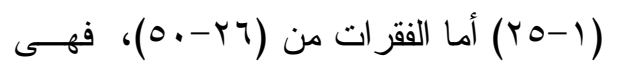

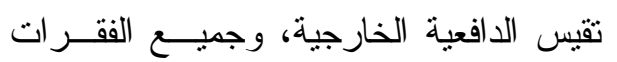

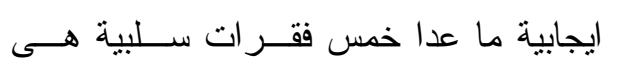

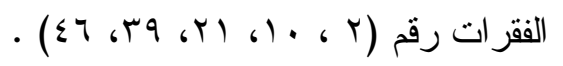
حساب الخصائص السيكومترية:

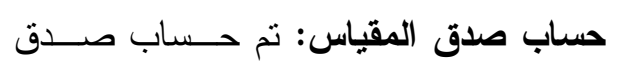

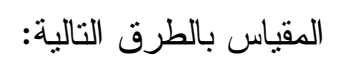

ا ـ الصدق المنطقي:

نم عرض عبار ات المقياس على 0 من

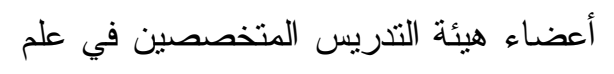

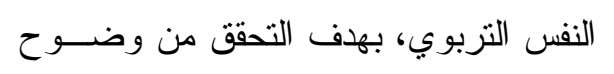

المقياس الأساسية، كما قامت بحساب الثبات

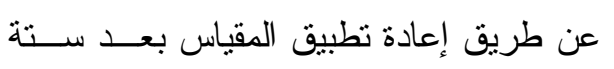

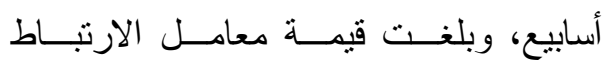

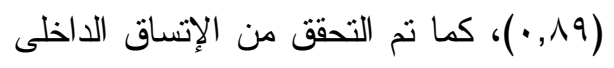
لفقر ات المقياس. أما فى الدر اسة الحالية قامت الباحثـــة

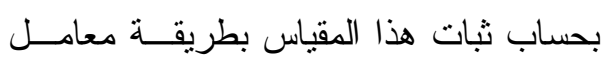
ألفا-كرونباخ، وبلغت قيمتــهـ علــى أبعـاد

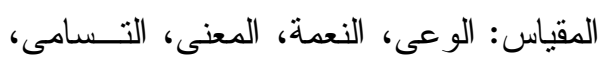

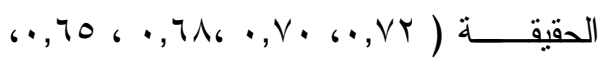

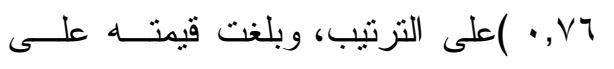

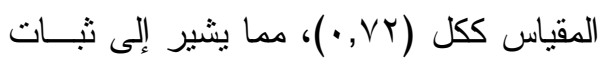

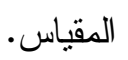
ثالثا: مقياس الدافعية للتعلم: يهدف المقياس إلى قيــاس الدافعيـــة

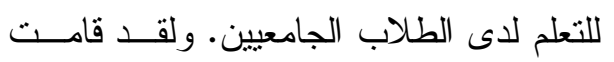
الباحثة بإعداد هذا المقياس بعد الإطلاع على لجى لإسلى

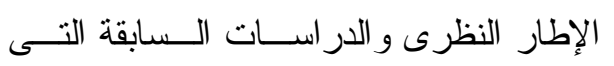
تتاولت الدافعيــة للــتعلم مثـــل دراســـات: Takahashi,2018)

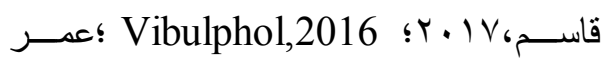

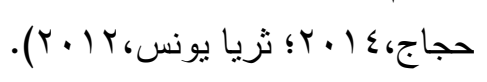

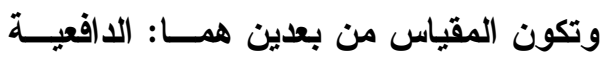
الا اخلية و الافوعية الخارجية:

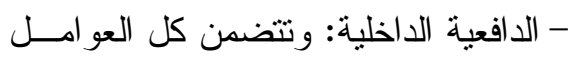

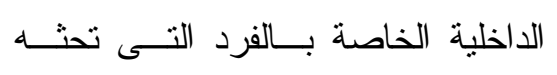

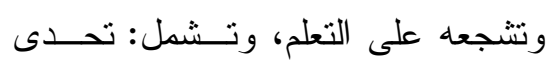
الفرد لذاته و استعداده لبذل جهد فئ هذه ونه 
يوضتح فؤاد أبو حطــب وآخــرون

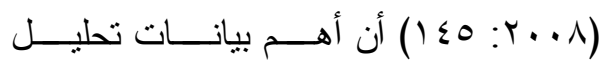

المفردات المتصلة بصدق محتوى الاختبــار

ككل هو ما يسمى بصدق المفردات، وهــــا

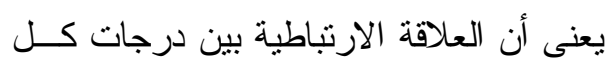

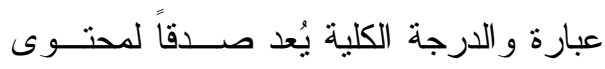

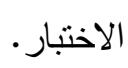

ونم حساب معاملات الارتباط بــين

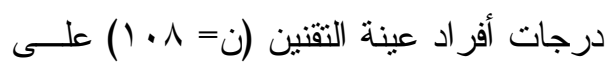

كل فقرة من فقر ات المقياس، و الدرجة الكلية

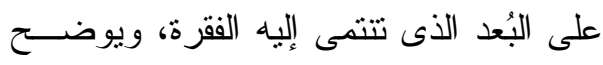

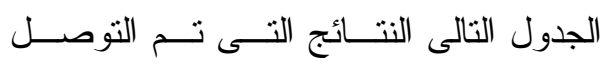

بنوده، ومناسبتها لأبعاد المقياس، وتم تعديل

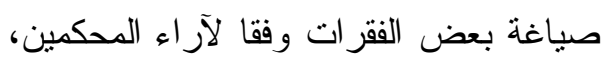

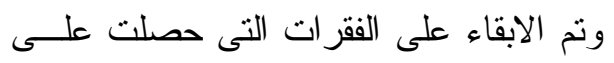

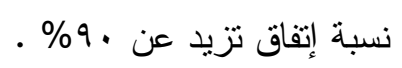
r ـ صدق المحك:

حيث تم حساب معامل الارثباط بـين

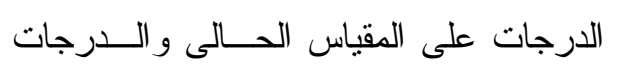

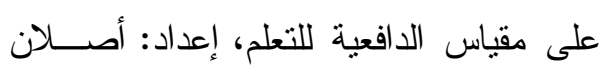

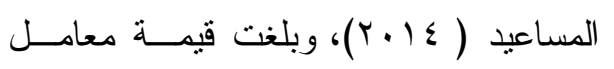

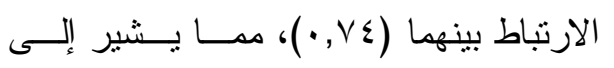
صدق المقياس.

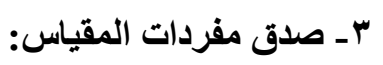
إليها:

أولاً: صدق فقرات البعد الأول (الدافعية الداخلية):

جدول (r)

معامل الارتباط بين الدرجات على كل فقرة من فقرات البعد الأول (الدافعية الا(خلية)

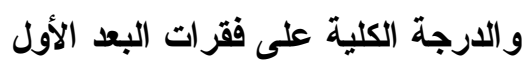

\begin{tabular}{|c|c|c|c|c|c|c|c|c|}
\hline مستوى الدلاة & معامل الارتباط & رقم الفقرة & مستوى الدلالة & معامل الارتباط| & الفقرة & مستوى الدلالة & معامل الارتباط & رقمق \\
\hline$\cdot, \cdot 1$ & $\cdot, 91$ & 19 & $\cdot, \cdot 1$ & $\cdot, 9 \leq$ & 1. & $\cdot, \cdot 1$ & $\cdot, \wedge \vee$ & 1 \\
\hline$\cdot, \cdot 1$ &., 01 & $r$. & $\cdot, \cdot 1$ &.$\wedge \mathrm{V}$ & 11 & $\cdot, \cdot 1$ & $\cdot, 01$ & r \\
\hline$\cdot, \cdot 1$ & $\cdot, 0 \leqslant$ & YI & غير دالة & $\cdot, \cdot V$ & IT & $\cdot, \cdot 1$ & . 77 & $r$ \\
\hline$\cdot, \cdot 1$ & $\cdot, r_{0}$ & rr & $\cdot, \cdot 1$ & $\cdot, 94$ & Tr & $\cdot, \cdot 1$ & $\cdot, \varepsilon$. & $\varepsilon$ \\
\hline$\cdot, \cdot 1$ & $\cdot, 7 r$ & rr & $\cdot, \cdot 1$ & $\cdot, r V$ & $1 \leq$ & $\cdot, \cdot 1$ & $\cdot, \leqslant \wedge$ & 0 \\
\hline$\cdot, \cdot 1$ & $\cdot, \vee>$ & $r \leq$ & $\cdot, \cdot 1$ & $\cdot, 0 \mathrm{~V}$ & 10 & $\cdot, \cdot 1$ & $\cdot, \wedge 9$ & 7 \\
\hline \multirow[t]{3}{*}{$\cdot, \cdot 1$} & $\cdot, V Y$ & ro & $\cdot, \cdot 1$ & $\cdot$, ro $_{0}$ & 17 & غير دالة & $\cdot, I^{\prime}$ & V \\
\hline & & & $\cdot, \cdot 1$ & $\cdot, \leq 0$ & iv & $\cdot, \cdot 1$ & $\cdot, \leqslant \varepsilon$ & $\wedge$ \\
\hline & & & غير دالة & $\cdot, \cdot 7$ & 11 & $\cdot, \cdot 1$ & $\cdot, r V$ & 9 \\
\hline
\end{tabular}




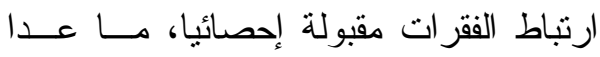

تــشير نتــائج جــدول (Y) إلــى أن

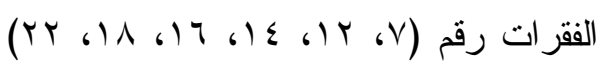
معاملات الارتباط بين درجات فقر ات البعـد ندان تز اوحت قيم معامـلـ الارتبــاط لهـــا بــين

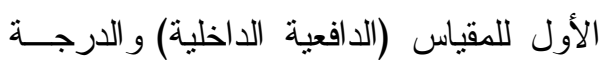
منخفضة وغير دالة إحصائيا لذلك تم استبعاد

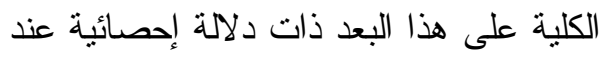
هذه الفقر ات.

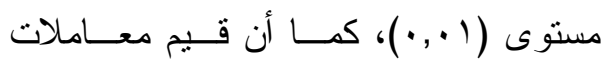
ثانياً: صدق فقرات البعد الثانى( الدافعية الخارجية): جدول (r)

معامل الارتباط بين الدرجات على كل فقرة من فقرات البعد الثانى (الدافعية الخارجية) و الدرجة الكلية على فقرات البعد الثانى

\begin{tabular}{|c|c|c|c|c|c|c|c|c|}
\hline مستوى الدلالة & معامل الارتباط & رقم الفقرة & مستوى الدلالة & معامل الارتباط & رقف & مستوى الدلاةة & معامل الارتباط & رقمق \\
\hline$\cdot, \cdot 1$ & $\cdot, 79$ & $\varepsilon \varepsilon$ & $\cdot, \cdot 1$ & $\cdot, 7)$ & ro & $\cdot, \cdot 1$ & $\cdot, \leqslant 9$ & $r y$ \\
\hline$\cdot, \cdot 1$ & $\cdot, v \cdot$ & $\leqslant 0$ & $\cdot, \cdot 1$ & $\cdot, V \leqslant$ & 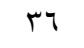 & $\cdot, \cdot 1$ & $\cdot, \wedge$. & $r V$ \\
\hline$\cdot, \cdot 1$ & $\cdot, \sum V$ & $\leqslant 7$ & غير دالة & $\cdot, \cdot 9$ & rv & $\cdot, \cdot 1$ & $\cdot, \vee \cdot$ & rᄉ \\
\hline$\cdot, \cdot 1$ & $\cdot, 7 \wedge$ & $\leqslant V$ & $\cdot, \cdot 1$ & $\cdot, V \vee$ & ऍی & $\cdot, \cdot 1$ & $\cdot, \leqslant 7$ & rq \\
\hline$\cdot, \cdot 1$ & $\cdot, \wedge$. & $\varepsilon \wedge$ & $\cdot, \cdot 1$ & $\cdot, r q$ & rq & $\cdot, \cdot 1$ & $\cdot, V \uparrow$ & r. \\
\hline$\cdot, \cdot 1$ & $\cdot, 79$ & $\leq 9$ & غير دالة & $\cdot, \cdot V$ & $\varepsilon$. & $\cdot, \cdot 1$ & צT, • & M \\
\hline \multirow[t]{3}{*}{$\cdot, \cdot 1$} & $\cdot, 0$ & 0 . & $\cdot, \cdot 1$ & $\cdot, V_{1}$ & «1 & $\cdot, \cdot 1$ & $\cdot, 77$ & rt \\
\hline & & & $\cdot, \cdot 1$ & •,$\varepsilon r$ & $\varepsilon r$ & $\cdot, \cdot 1$ & $\cdot, \leqslant \vee$ & זr \\
\hline & & & $\cdot, \cdot 1$ & $\cdot, \varepsilon$. & $\varepsilon r$ & $\cdot, \cdot 1$ & $\cdot, \vee_{0}$ & $r \varepsilon$ \\
\hline
\end{tabular}

\section{الاتساق الاخلى للمقياس:}

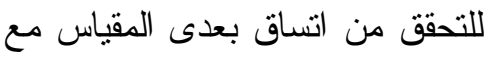

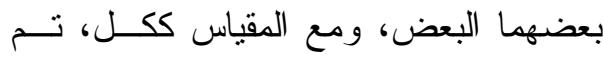
حساب معاملات الارتباط بين درجات أفراد الدمان

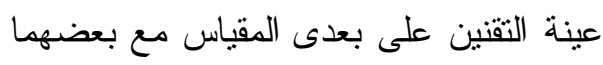

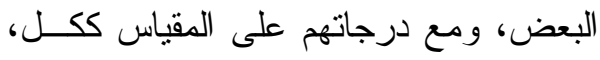

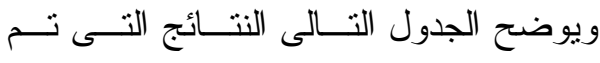

التوصل إليها:

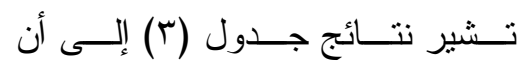
معاملات الارنباط بين درجات فقر ات البعـد

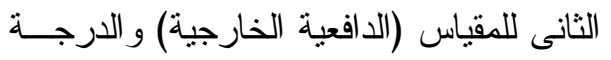

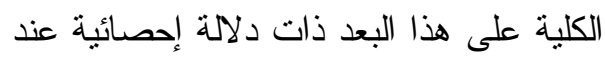

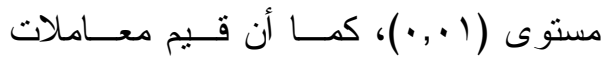

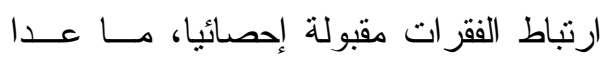

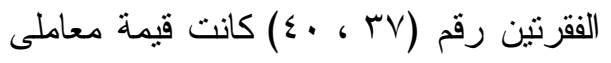

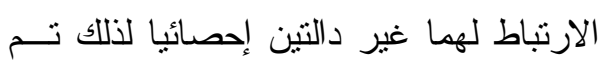
استبعاد هاتين الفقرتين. 


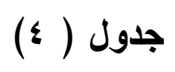

معاملات الارتباط بين الدرجات على كل بُعد من بعدى المقياس

\begin{tabular}{|c|c|c|}
\hline الدافعية الخارجية & الا(فعية الداخلية & بعدى المقياس \\
\hline & - & الدافعية الداخلية \\
\hline- & $\cdot, \wedge 1$ & الدافعية الخارجية \\
\hline$\cdot, 9 r$ & $\cdot 90$ & الارجة الكلية على المقياس \\
\hline
\end{tabular}

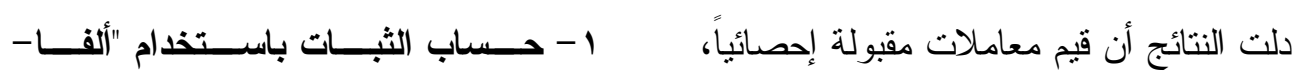

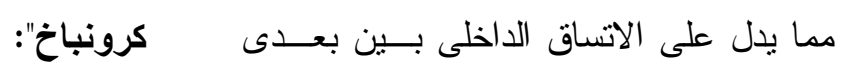
قامت الباحثة بحساب ثبات المقيــاس

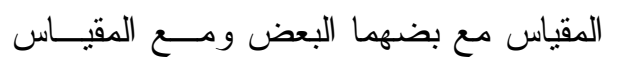

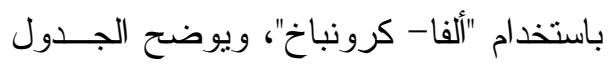
التالى قيم معاملات الثبات لبعدى المقياس: حساب ثبات المقياس: قامت الباحثة بحساب ثبات المقيــاس

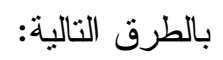

(0) جدول

معاملات الارتباط باستخدام "ألفا- كرونباخ"

\begin{tabular}{|c|c|}
\hline قيم معاملات الارتباط باستخدام "ألفا-كرونباخ" & بعدى المقياس \\
\hline$\cdot, 9$. & الدافعية الداخلية \\
\hline$\cdot, 9 r$ & الدافعية الخارجية \\
\hline$\cdot, 90$ & المقياس الكلى \\
\hline
\end{tabular}

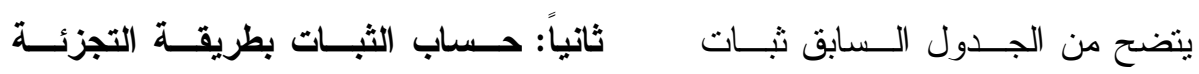

المقياس ككل، وثبات أبعاده، حيث كانت قيم النصفية:

قامت الباحثة بحساب ثبات المقيــاس

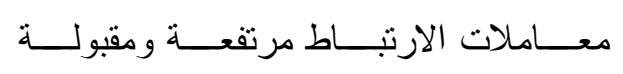

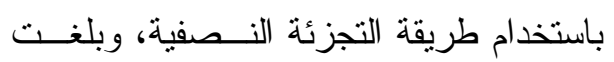
احصائيا. 
r، ( ) على الترتيب. ويتم التصحيح بطريقة

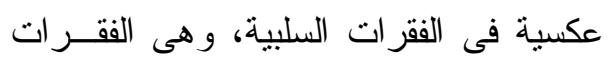

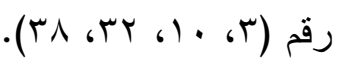

\section{نتائج الدراسة وتفسيرها:}

فيما يلى عــرض لنتــــائج الدر اســـة

$$
\text { و تقسير ها: }
$$

أولا: نتائج الفرض الأول وتفسيرها:

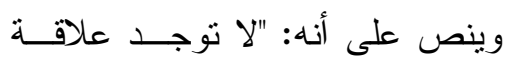

ارتباطية ذات دلالة إحصائية بين درجـات لونات

الطلاب على مقياس عادات العقل ودرجاتهم

$$
\text { على مقياس الذكاء الروحى". }
$$

وتمت معالجة هذا الفرض إحـــئيًاً

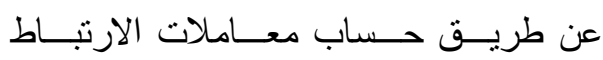

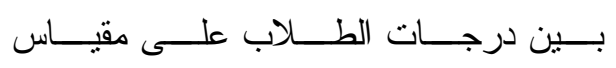

عادات العقل بأبعاده ودرجاتهم على مقيــاس

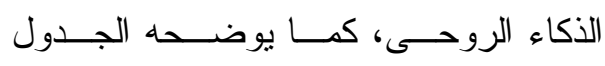

التالى:

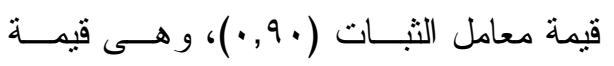
مرتفعة، مما يشير إلى ثبات المقياس. الصورة النهائية للمقياس:

بعـــــ إجـــر اء تعـــديلات الــسادة

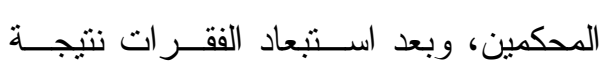

لحساب صدق المفردات، أصبح عدد فقرات

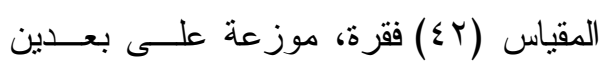

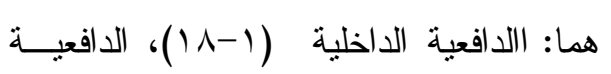
الخارجية (9 (1-r ع).

\section{طريقة تصحيح المقياس:}

يتم تصحيح المقياس فى ضو ء مقياس

خماسى (تتطبق تمامًا، تتطبق بدرجة كبيرة،

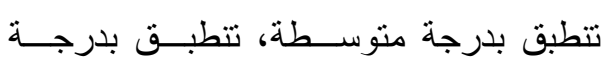
ضعيفة، لا تتطبق على الإطلاق) ويتم تقدير الدرجات كالتالى، حيث تأخذ الاســتجابات: (تتطبق تمامًا، نتطبق بدرجة كبيرة، تتطبــق

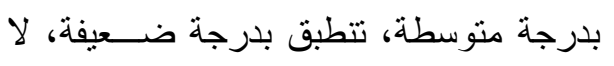

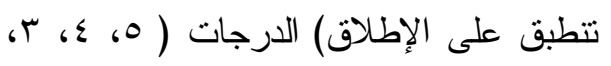


جدول(7)

معاملات الارتباط بين درجات الطلاب على مقياس عادات العقل بأبعاده

ودرجاتهم على مقياس الأكاء الروحى بأبعاده

\begin{tabular}{|c|c|c|c|c|c|c|c|c|c|c|}
\hline \multicolumn{2}{|c|}{ الحقيقة } & \multicolumn{2}{|c|}{ التسامى } & \multicolumn{2}{|c|}{ المعنى } & \multicolumn{2}{|c|}{ النعمة } & \multicolumn{2}{|c|}{ الوعى } & \multirow{3}{*}{ كادات/اء الروحى } \\
\hline مستوى & معامل & مستوى & معامل & مستوى & معامل & مستوى & معامل & مستوى & معامل & \\
\hline الدلالة & الارتباط & الدلاةة & الارتباط & الدلالة & الارتباط & الدلاةة & الارتباط & الدلالة & الارتباط & \\
\hline$\cdot, \cdot 1$ & $\cdot, 07$ & $\cdot, \cdot 1$ & $\cdot, \leqslant T$ & $\cdot, \cdot 1$ & $\cdot, \varepsilon \vee$ & $\cdot, \cdot 1$ & $\cdot, \varepsilon r$ & $\cdot, \cdot 1$ & די. & المثابرة \\
\hline$\cdot, \cdot 1$ & $\cdot, \leqslant Y$ & $\cdot, \cdot 1$ & • & $\cdot, \cdot 1$ & •, Tr & $\cdot, \cdot 1$ & • & $\cdot, \cdot 1$ & $\cdot, r$ & إدارة الاندفاعية \\
\hline غير دالة & $\cdot, \cdot 1$ & غير دالة & $\cdot, .0$ & غير دالة & $\cdot, \cdot 9$ & غير دالة & $\cdot, 1 Y$ & غير دالة & $\cdot, 1 \leq$ & الإصغاء بتقهح \\
\hline غير دالة & $\cdot, 11$ & غير دالة & $\cdot, \cdot \leq$ & غير دالة & $\cdot, \cdot 1$ & غير دالة & $\cdot, \cdot r$ & غير دالة & $\cdot, \cdot 1$ & التفكير المرن \\
\hline غير دالة & $\cdot, \cdot V$ & غير دالة & $\cdot, \cdot \leq$ & غير دالة & $\cdot, \cdot 9$ & $\cdot, .0$ & $\cdot, 1 V$ & $\cdot, \cdot 1$ & $\cdot, 19$ & التفكير فى التفكير \\
\hline$\cdot, \cdot 1$ & זr, & $\cdot, \cdot 1$ & $\cdot, Y q$ & $\cdot, \cdot 1$ & $\cdot, r V$ & $\cdot, \cdot 1$ & $\cdot, r \cdot$ & $\cdot, \cdot 1$ & $\cdot, r \cdot$ & الاجتهاد من أجل \\
\hline غير دالة & $\cdot, \cdot 1$ & غير دالة & $\cdot, \cdot 1$ & غير دالة & $\cdot, \cdot \wedge$ & غير دالة & $\cdot, 1 K$ & $\cdot, \cdot 1$ & $\cdot, r \cdot$ & النساؤل \\
\hline غير دالة & $\cdot, .0$ & غير دالة & $\cdot, \cdot r$ & غير دالة & $\cdot, \cdot \wedge$ & $\cdot, \cdot 1$ & $\cdot, 1 \wedge$ & $\cdot, \cdot 1$ & $\cdot, Y_{1}$ & تطبيق المعارف \\
\hline$\cdot, \cdot 1$ & $\cdot, \varepsilon r$ & $\cdot, \cdot 1$ & • & $\cdot, \cdot 1$ & . & $\cdot, \cdot 1$ & ,,$\mu_{T}$ & $\cdot, \cdot 1$ & $\cdot, r)$ & التفكيرو التو اصل \\
\hline غير دالة & $\cdot, 1$ & غير دالة & $\cdot, \cdot r$ & غير دالة &., .0 & غير دالة &., $1 r$ & $\cdot, \cdot 1$ & $\cdot, r \cdot$ & جمع البيانات \\
\hline$\cdot, \cdot 1$ & $\cdot, \leqslant 7$ & $\cdot, \cdot 1$ & $\cdot, Y_{4}$ & $\cdot, \cdot 1$ & $\cdot, \varepsilon$. & $\cdot, \cdot 1$ & $\cdot, r$ & $\cdot, \cdot 1$ & •, rT & التصور و التخيل \\
\hline$\cdot, \cdot 1$ & $\cdot, M$ & $\cdot, \cdot 1$ & $\cdot, \leq \varepsilon$ & $\cdot, \cdot 1$ & $\cdot, \varepsilon 1$ & $\cdot, \cdot 1$ & $\cdot, \Gamma \wedge$ & $\cdot, \cdot 1$ & $\cdot, \varepsilon$. & الثغف للتعلم \\
\hline غير دالة & $\cdot, \cdot 1$ & غير دالة & $\cdot, .0$ & غير دالة & $\cdot, \cdot r$ & غير دالة & $\cdot, I r$ & $\cdot, \cdot 1$ & $\cdot, 1 \leq$ & الإقدام على المخاطر \\
\hline غير دالة & $\cdot, 11$ & غير دالة & $\cdot, \cdot \varepsilon$ & غير دالة & $\cdot, \cdot 1$ & غير دالة & $\cdot, \cdot r$ & غير دالة & $\cdot, \cdot 1$ & التحلى بالدعابة \\
\hline غير دالة & $\cdot, \cdot 1$ & غير دالة & $\cdot, .0$ & غير دالة & $\cdot, \leqslant 7$ & غير دالة & $\cdot, 14$ & غير دالة &., $1 \leqslant$ & التفكير التبادلى \\
\hline$\cdot, \cdot 1$ & • & $\cdot, \cdot 1$ & $\cdot, \leqslant \vee$ & غير دالة & $\cdot, \cdot 9$ & $\cdot, \cdot 1$ & $\cdot, \leqslant 9$ & $\cdot, \cdot 1$ & $\cdot, \leqslant 1$ & الاستعد اد للتعلم \\
\hline$\cdot, \cdot 1$ & $\cdot, \Gamma \wedge$ & $\cdot, \cdot 1$ & r & $\cdot, \cdot 1$ & זr, • & $\cdot, \cdot 1$ & $\cdot, r \wedge$ & $\cdot, \cdot 1$ & $\cdot, \Gamma \wedge$ & عادات العقل \\
\hline
\end{tabular}

وهذا يشير إلى أن الفرد الذى يمتلـــــ

يتضـح من الجدول الــسابق وجــود

مستوى مرتفع من العادات العقلية تتو افر لديه

علاقة إرتباطية موجبة ذات دلالة إحـصائية

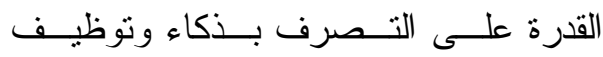

عند مسنوى ا +,. ، بين الــدرجات الكليــة

السلوكيات الذكية فى كل مو اقف الحياة التى لهن

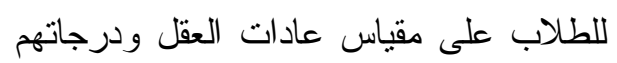

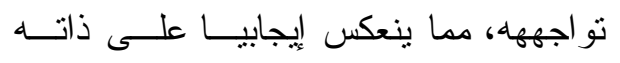

على جميع أبعاد مقياس الذكاء الروحى. 
ومحاولة التوصل إلى حلول جديدة ومبتــــرة

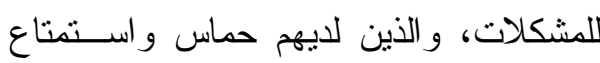

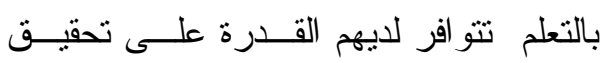
الإتزان و الرضا و السعادة الداخلية. كما يتضح كذلك من الجدول الــسابق عدم وجود علاقة إرنباطية دالة إحصائيا بين درجات الطلاب على العادت العقلية الأتبـــة:

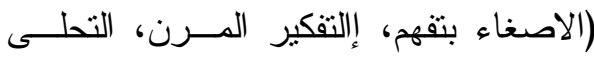

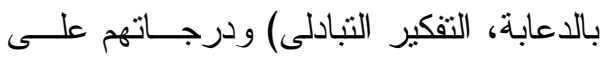
جميع الأبعاد الفرعية الخمسة لمقياس الذكاء الروحى(الوعى، النعمة، المعنى، التــسامى، (الحقيقة). ويمكن تفسير ذلك بأن الطلاب الذين يتصفون بحسن الاستماع للآخرين، وتغييــر بان

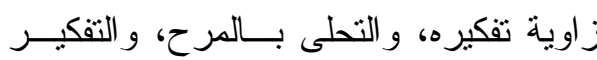

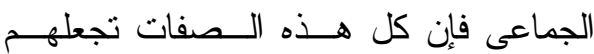
ينشغلون بالتفاعل الجماعى و الانـــماج مـــع

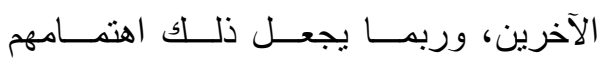
بالنو احى الخارجية ، وربما يشغلهم ذلك عن ورن لتهن

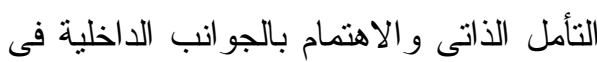

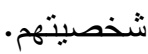
ويشير الجدول السابق إلـى وجــود علاقة إرتباطية موجبة دالة إحـصائيا عنــــ

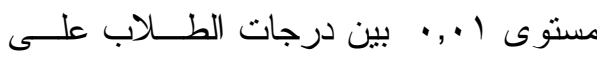
عادة التفكير فى التفكير ودرجاتهم على بعـد ليند

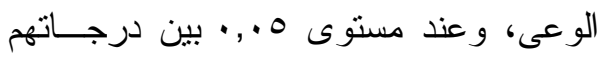
على هذه العادة، ودرجاتهم على بعد النعمة.
ويجعله أكثر استعدادا لمواجهــة المواقــف الصعبة، ويمكنه من تحقيق النوازن و الرضا

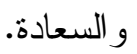
وتتفق هذه النتيجة مع ما أثنار إليـــه

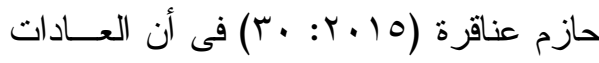

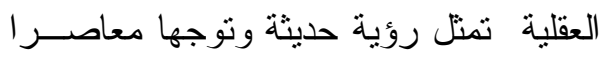

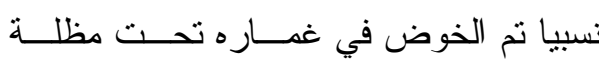

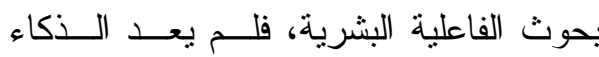
المسؤول الوحيد عن نجاح المتعلم في حياته العلمية و العملية، بل ينبغي أن يسلك المــتعلم سلوكا ذكيا يصبح في ظله محترمـــا لعقلــهـ ولقدر اته و إمكاناته اللامحدودة، كي يصل في إلى فلى عقل يمتلك عـــادات عقليــة أكثـــر فاعليـــة و إنتاجية وكفاءة( حازم عناقرة، • r 10 1 • ب). كما يتضح من الجــدول الــسابق: وجود علاقة إرتباطية موجبة دالة إحــصائيا

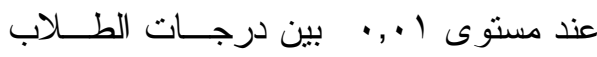

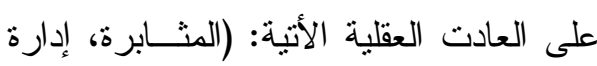
الاندفاعية، الاجتهاد من أجل الدقة، التفكيــر و التو اصل، التصور و التخيل، الثغف للنعلم) ودرجاتهم على جميع الأبعاد الفرعية الخمسة لمقياس الذكاء الروحسى (الـــوعى، النعــــة، المعنى، التشامى، الحقيقة). ويمكن تفسير ذللك بأن الطلاب الذين

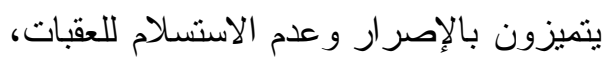
و التفكير بتأنى، و التقكير الدقيق قبـــل إتخــاذ

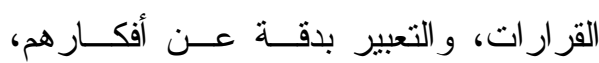


الفرد أن يكون فادر ا علــى التوفيـق بـين

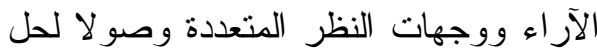
المشكلة وهو ما ينو افر فى بعد (الوعى).

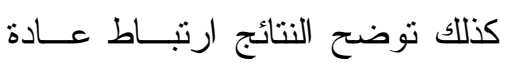

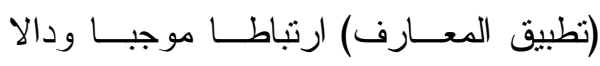

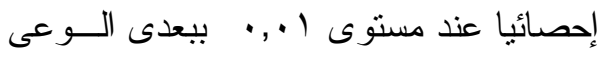

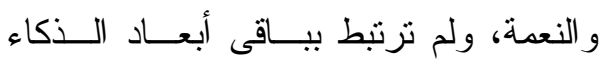

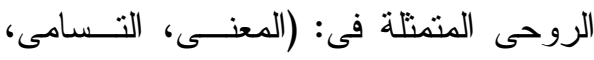

(الحقيقة).

وربما يعود ذلك إلى أن عادة (تطبيق المعارف) تتضمن تطبيق المعارف الـسـابقة على المو اقف الجديدة، وهذا يتطلب من الفرد

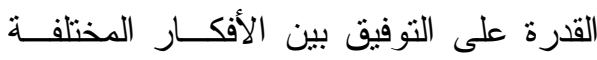

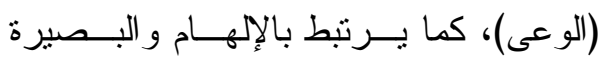

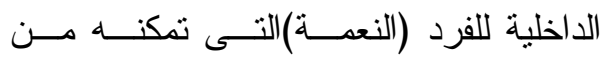
الوصول لأفضل الحلول.

كما تشير النتائج إلى ارتبــاط عــادة لـادة الاستعداد للتعلم ارتباطا موجبا ودالا إحصائيا

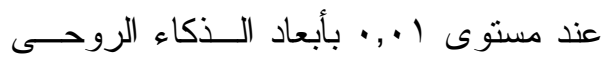

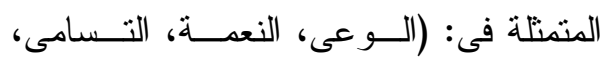
الحقيقة)، ولم ترنبط ببعد المعنى. ويمكن تقسير ذللك بأن استعداد الفرد

للتعلم المستمر وتطوير ذاته يرتبط بقدرتـــه

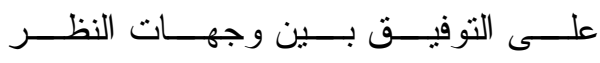

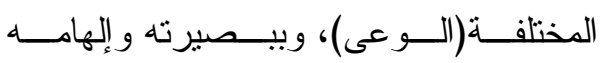

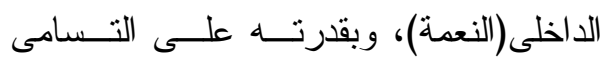

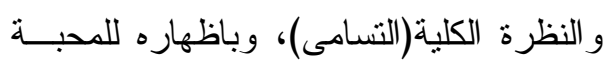

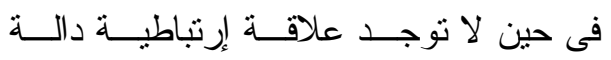

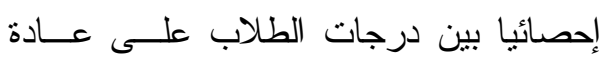
التقكير فى التفكير ودرجـاتهم علــى أبعــاد الذكاء الروحى(المعنى، التسامى، الحقيقة).

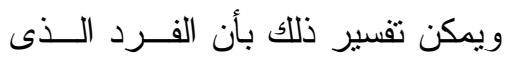
يمتلك القدرة علـى التفكيــر فــى أفكــاره وتقييمها، يكون لديه القدرة على التوفيق بين

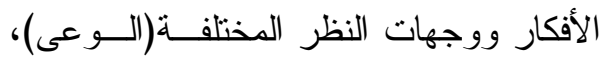

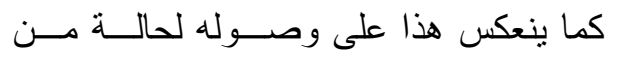

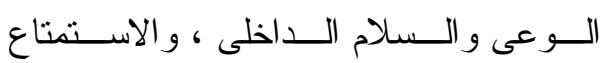
باللحظة الحالية( النعمة).

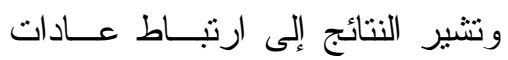
العقل التالية: (التساؤل، جمع البيانات، الإقدام على المخاطر ) ارتباطا موجبا ودالا إحصائيا

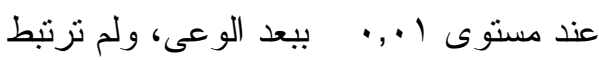

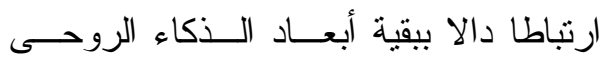

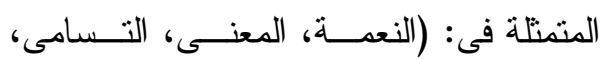
(الحقيقة). وقد يرجع ذلك إلى الارنباط المنطقى بين عادات العقل الثثلاث وبعد الوعى، فالفرد الذى يتصف بقدرته على طرح التـساؤلات

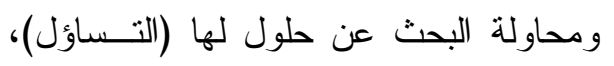

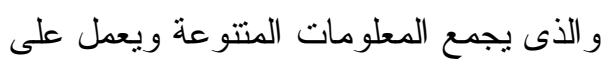

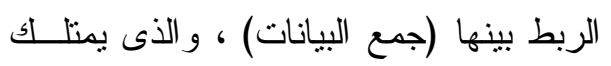

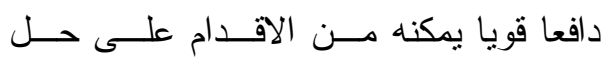

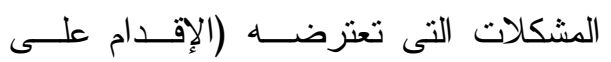

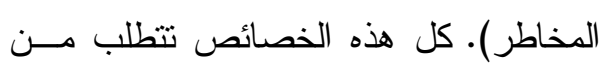


وتمت معالجة هذا الفرض إحــصائيا

عن طريت حساب معاملات الارتبــاط بــين

درجات الطلاب على مقياس عادات العقـلـ

بأبعاده ودرجاتهم على مقياس الدافعية للتعلم

، كما يوضحه الجدول التالى:
و السـلام( الحقيقة).و لا يرثبط بتقسير المعنـى أو الاحساس به (المعنى). ثانيا: نتائج الفرض الثاني الثانى وتفسيرها:

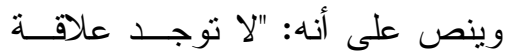
ارتباطية ذات دلالة إحصائية بين درجــات الطلاب على مقياس عادات العقل ودرجاتهم على مقياس الدافعية للتعلم".

جدول(v)

معاملات الارنباط بين درجات الطلاب على مقياس عادات العقل بأبعاده ودرجاتهم على مقياس الدافعية للتعلم ببعديه

\begin{tabular}{|c|c|c|c|c|}
\hline \multicolumn{2}{|c|}{ الدافعية الخارجية } & \multicolumn{2}{|c|}{ الدافعية الداخلية } & \multirow{2}{*}{ عادات العقل } \\
\hline مستوى الالالة & معامل الارتباط & مستوى الدلالة & معامل الارتباط & \\
\hline$\cdot, \cdot 1$ & $\cdot, r V$ & $\cdot, \cdot 1$ & .4 & المثابرة \\
\hline$\cdot, \cdot 1$ & $\cdot, 19$ & $\cdot, \cdot 1$ & $\cdot, \varepsilon$. & إدارة الاندفاعية \\
\hline غير دالة & $\cdot, .9$ & غير دالة & $\cdot, 11$ & الإصغاء بتفهم \\
\hline غير دالة & $\cdot, 1$ & غير دالة & $\cdot, \cdot \varepsilon$ & التفكير المرن \\
\hline غير دالة & $\cdot, \cdot V$ & غير دالة & $\cdot, 19$ & التفكير فى التفكير \\
\hline$\cdot, .0$ & $\cdot, 11$ & غير دالة & $\cdot, \cdot 9$ & الاجتهاد من أجل الدقة \\
\hline غير دالة & $\cdot, \cdot r$ & $\cdot, \cdot 1$ & $\cdot, Y_{T}$ & التساؤل \\
\hline غير دالة & $\cdot, \cdot \varepsilon$ & غير دالة & $\cdot, \cdot 9$ & تطبيق المعارف \\
\hline$\cdot, \cdot 1$ & $\cdot, 19$ & غير دالة & $\cdot, \cdot V$ & التقكير و التو اصل \\
\hline غير دالة & $\cdot, .0$ & $\cdot,+1$ & $\cdot, r q$ & جمع البيانات \\
\hline$\cdot, \cdot 1$ & $\cdot$, ro & غير دالة & $\cdot, \cdot \wedge$ & التصور و التخيل \\
\hline$\cdot, \cdot 1$ & $\cdot, r \cdot$ & $\cdot, \cdot 1$ & $\cdot, r \leq$ & الثغف للتعلم \\
\hline غير د دالة & $\cdot, \cdot 9$ & $\cdot, \cdot 1$ & $\cdot, r \cdot$ & الإقدام على المخاطر \\
\hline غير دالة & $\cdot, 1$ & غير دالة & $\cdot, 11$ & التحلى بالدعابة \\
\hline غير دالة & $\cdot, .9$ & غير دالة & $\cdot, \cdot \varepsilon$ & التفكير التبادلى \\
\hline$\cdot, \cdot 1$ & $\cdot, r$. & $\cdot, \cdot 1$ & $\cdot, 1 \mathrm{r}$ & الاستعد اد للتعلم \\
\hline$\cdot, \cdot 1$ & $\cdot, r \leq$ & $\cdot, \cdot 1$ & (דוז, & عادات العقل ككل \\
\hline
\end{tabular}


للتعلم، الاستعداد للتعلم) وكل مــن الدافعيـــة الداخلية، و الدافعية الخارجية.

ويمكن تفسير ذلك بأن هذه العـادات

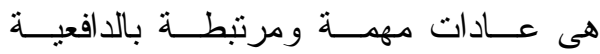
بمفهومها العام وبكل بعد من بعديها، لارتباط هذه العادات بتوجيه المــتعلم نحـــو تحقيـق أهدافه سو اء كان مدفوعا داخليا أو خارجيــا للنعلم.

ويوضح الجدول السابق وجود علاقة

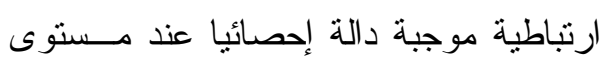
ا •, · بين درجات الطلاب على بعد الدافعية

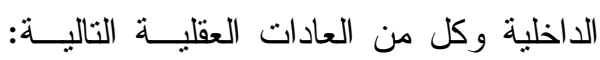

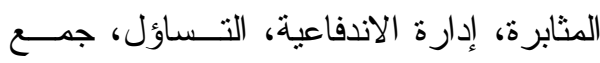

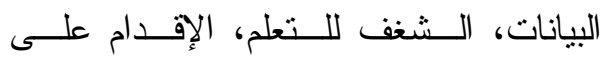
المخاطر ، الاستعداد للتعلم.

كما يتــضح عــدم وجــود علاقهـة

ارتباطية دالة إحصائيا بين الدافعية الداخليـــة وكل من العادات التاليــة:الإصـــــاء بــتـفهم، التفكير المرن، التقكير فى التفكير، الاجتهـاد من أجل الدقة، تطبيق المعــارف، التفكيـر

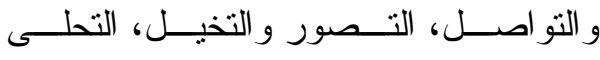

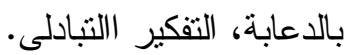

ويمكن تفسير هذه النتيجة بأن العادات

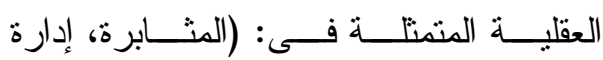

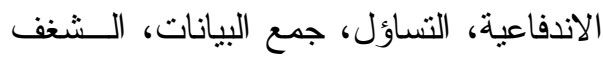

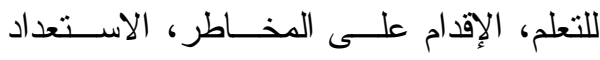

يتضح من الجدول الــسابق وجـود

علاقة إرتباطية موجبة دالة إحــصائيا عنــــ مستوى ا.,. بين الدرجات الكلية للطلاب على مقياس عادات العقل ودرجاتهم الكليــة على مقياس الدافعية للتعلم.

فكلما ارتفعت الدرجة الكلية للطالــب

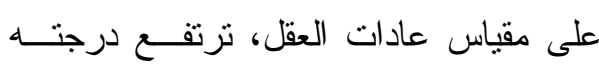
الكلية على مقياس الدافعية للتعلم. ونتفق هذه النتيجة مع مــا أوضــحه

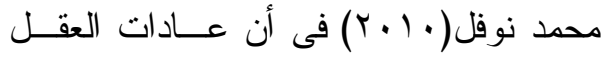
جعلت المتعلم بنطلق نحــو عــالم أرحـبـ،

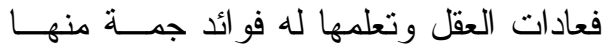
أنها تجعل العقل فعالا وتصرفه عن الخمول،

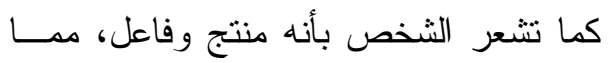
يشعره بالحيوية و الاستمتاع، وكل هذا يــؤثر إيجابيا على دافعيته للتعلم.

كما اتفقت هذه النتيجة مع ما توصلت

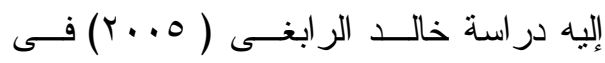

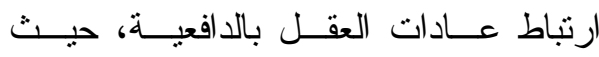

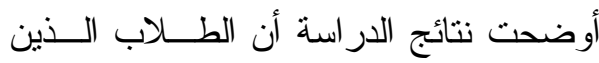

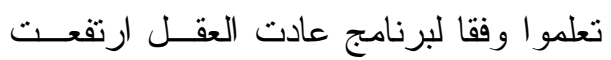

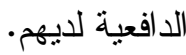
كما يتضح من الجدول السابق وجود علاقة ارتباطية بين كل من العادات العقليــة

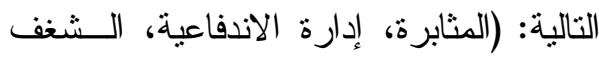




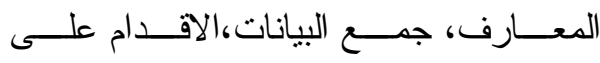
المخاطر ، التحلى بالدعابة، التقكير التبادلى.

ويمكن تفسير هذه النتيجة بأن العادات

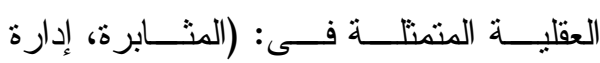

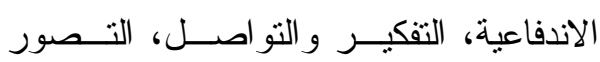

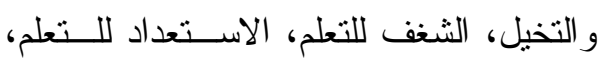

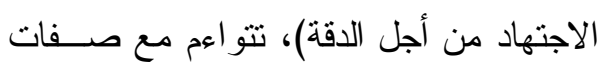

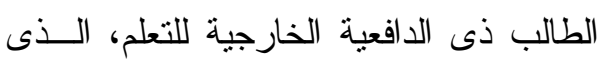
يتصف بأنه يدفع للتعلم لإرضـــاء الآخــرين

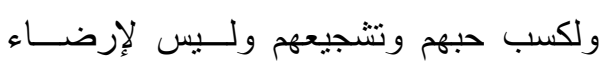
ذاته.

$$
\text { نتائج الفرض الثالث وتفسيرها: }
$$

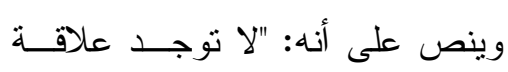

$$
\text { ارتباطية ذات دلالة إحصائية بين درجـات لونهات }
$$

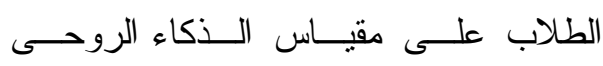
ودرجاتهم على مقياس الدافعية للتعلم". وتمت معالجة هذا الفرض إحسئئاً عن طريق حساب معاملات الارتبــاط بــين درجات الطلاب على مقياس الذكاء الروحى لإنى

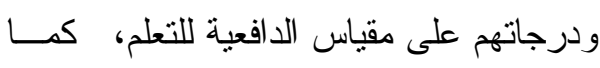

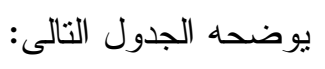

للتعلم)، نتسق وتتسجم مع صفات الطالب ذى

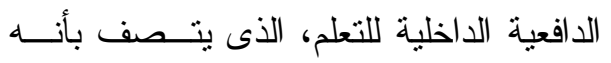
يحب التعلم ويستمتع به، ويقدم عليه مدفوعا

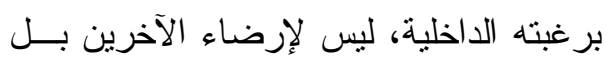

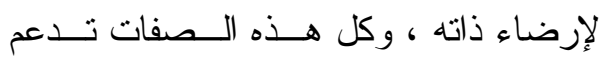
تو افر تلكك العادات العقلية لديه بصورة وله أكبـــر من بقية العادات العقلية الأخرى. وبالنــــبة للعلاقــة بــين الدافعيــة

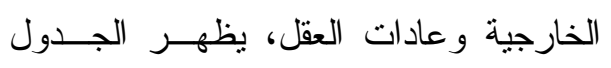
السابق وجود علاقة ارنباطية موجبـــة دالـــة

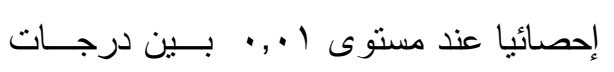

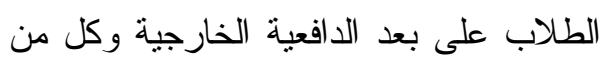

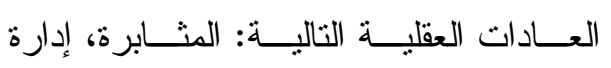

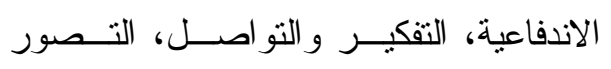

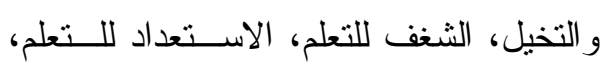

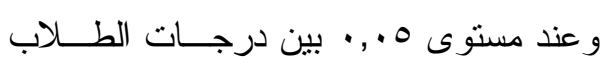

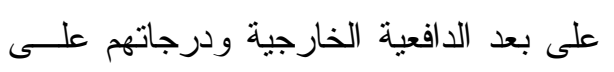
عادة الاجتهاد من أجل الدقة. بينما لم توجد علاقة ارتباطيــة دالـــة

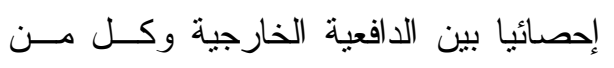

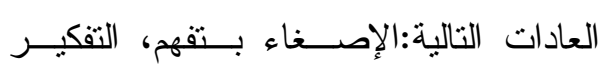

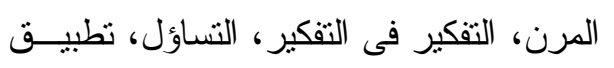




\section{جدول(^)}

معاملات الارتباط بين درجات الطلاب على مقياس الأكاء الروحى

ودرجاتهم على مقياس الأفعية للتعلم

\begin{tabular}{|c|c|c|c|c|}
\hline \multicolumn{2}{|c|}{ الدافعية الخارجية } & \multicolumn{2}{|c|}{ الدافعية الداخلية } & الدافعية للتعلم \\
\hline مستوى الدلالة & معامل الارتباط & مستوى الدلالة & معامل الارتباط & الذكاء الروحى \\
\hline غير دالة & r & $\cdot, ., 1$ & דז, & الوعى - الوعى \\
\hline$\cdot, ., 1$ & $\cdot, \mathrm{TV}$ & $\cdot, ., 1$ & $\cdot, r v$ & النعمة \\
\hline غير دالة & •, Ir & $\cdot, .0$ & $\cdot, I V$ & 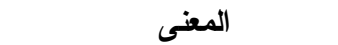 \\
\hline$\cdot, .0$ & $\cdot, I V$ & $\cdot, .1$ & •, YV & 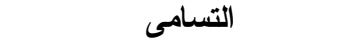 \\
\hline$\cdot, .1$ & •, TV & $\cdot, .1$ & • & الحقيقة \\
\hline$\cdot, .1$ & • & $\cdot, .1$ & · & الذكاء الروحى الكلى \\
\hline
\end{tabular}

ودالة احصائيا عند مستوى( (., •) بين كـلـ

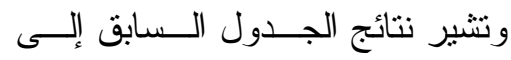

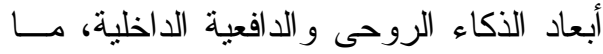

وجود علاقة إرتباطية موجبة دالة إحـصائيا

عدا بعد المعنى الذى ارتبط بالدافعية للــتعلم

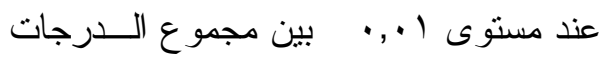

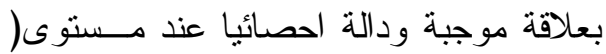

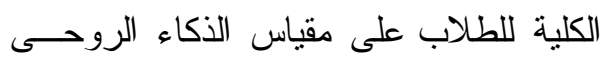

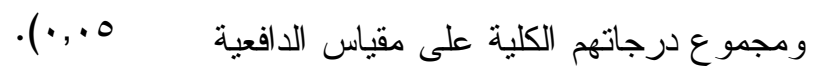

ويشير الجدول السابق إلــى وجــود

علاقة ارتباطية موجبة ودالة احصائيا عنــد ولدير

ويمكن تفسير ذلك بأن مردود الذكاء

مستوى (l .,.) بين كل من بعدى الـــكاء

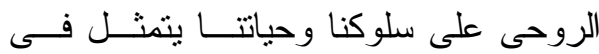

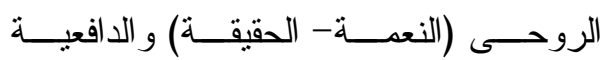

التعامل بحكمة مع المحن و الثـدائد، و اتخــاذ

الخارجية، كما توجد علاقة ارتباطية موجبة

مو اقف ايجابية منها ( عمرو شريف، 11 ـrج:

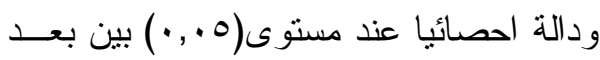

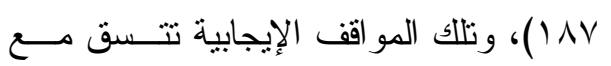

التسامى و الدافعية الخارجية.

الدافعية الداخلية التىى تجعل الفــرد مــدفوعا

وتوضح هذه النتيجة أنه كلما ارتفعت

نحو إثباع حاجاته و اهدافه المرتبطة بالتعلم.

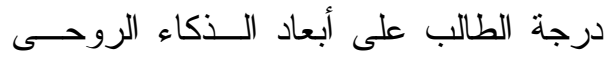

كما يتضح من الجدول السابق ارتباط

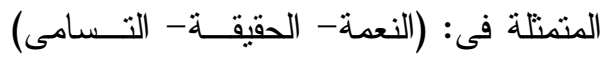

جميع أبعاد الذكاء الروحى الخمسة بالدافعية

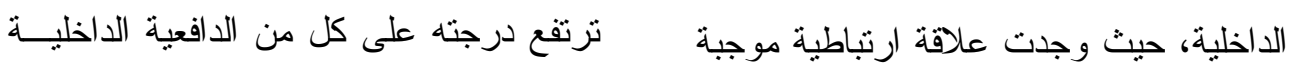

و الدافعية الخارجية. 
بينما لا توجد علاقة ارتباطية دالة إحـصصائيا بين كـلـل مــن هـــين البعــدين و الدافعيــة

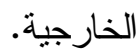

ويمكن تفسير ذللك بأن بعدى الــذكاء

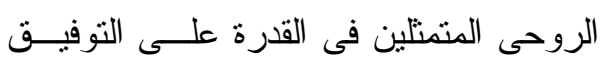
بين وجهات النظر (الــوعى)، و الاحسـاس

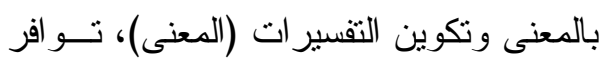
هذين البعدين يجعلان الفرد يقدم على الـــتعلم مدفو عا برغبة داخلية لإرضاء ذاته، وســـيا لئهين

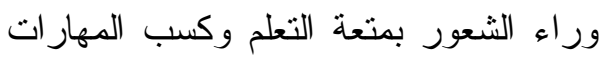

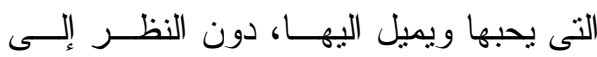
إرضاء رغبات الآخرين.

\section{نتائج الفرض الرابع وتفسيرها:}

وينص على أنه: " لا توجد فروق

ذات دلالة إحصائية بين متوسطات درجـات

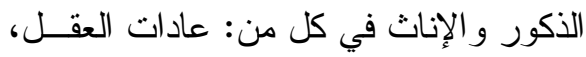
و الذكاء الروحى، ودافعية التعلم لدى طـــلاب

$$
\text { كلية التزبية بسو هاج". }
$$

أولا: الفروق بين الأكور والإناث فى عادات

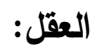

وللتحقق من هذا الفرض نم استخدام اختبــار

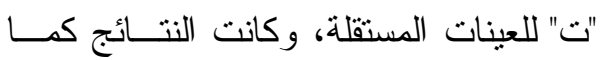

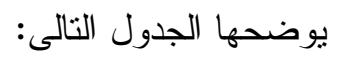

وتتفق هذه النتيجة مع أهمية الـذكاء

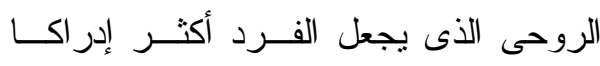

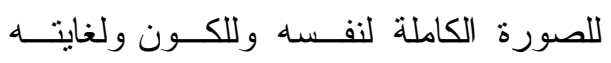

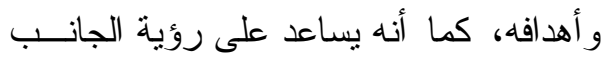

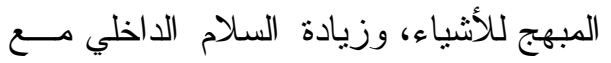

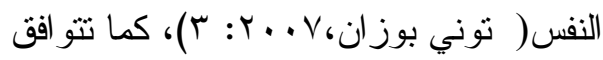
هذه النتيجـــة مـــع مـــا أثنــارت در اســــة Raftopoulos \& Bates (2011) الذكاء الروحي و القيم الروحانية نساعد علــى زيادة الوعي الذاتي. ويمكن تفسير تلك النتيجة بأن أبعـاد

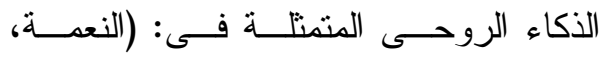

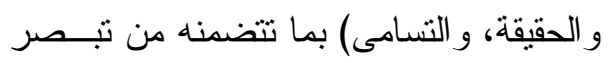

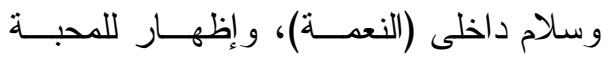

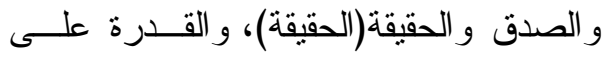

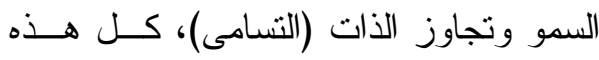
المكونات تجعل الفرد متحمسا تجاه تحقيــق أهدافه، ولديه طاقة لتحقيق هــذه الأهــداف

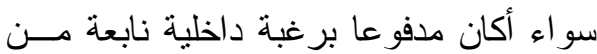

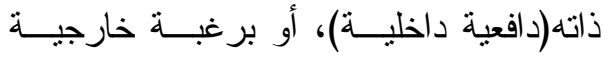
لاإرضاء الآخرين (دافعية خارجية). كما يتضح من الجدول السابق وجود

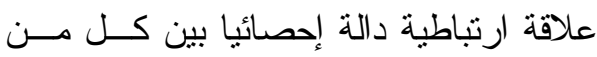
بعدى: الوعى و المعنى و الدافعيــة الداخليــة، 
جدول(9)

الفروق بين الأكور والإخاث فى عادات العقل

\begin{tabular}{|c|c|c|c|c|c|c|c|}
\hline \multirow{2}{*}{ مستوى الدلالة } & \multirow{2}{*}{ "تيمة } & \multicolumn{2}{|c|}{ إناث (ن = r r I ) } & \multicolumn{2}{|c|}{ ذكور (ن = } & \multirow[b]{2}{*}{ 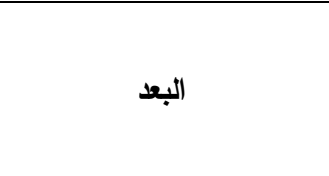 } & \multirow[b]{2}{*}{ م } \\
\hline & & الالحر اف & المتوسط & الآحر اف & المتوسط & & \\
\hline غير دالة & $1, \cdot v$ & $\varepsilon, \Gamma$. & $r \wedge, \cdot \wedge$ & $\varepsilon, r$. & Y^, 79 & المثابرة & 1 \\
\hline 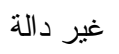 & $\cdot, Y_{7-}$ & $7, \cdot \varepsilon$ & $r q, 99$ & 0,01 & rq, ২V & إدارة الاندفاعية & r \\
\hline$\cdot, .0$ & Ү,тฯ- & 7,1 . & 部, TV & $0,1 r$ & T1,07 & الإصغاء بتقهم وتعاطف & r \\
\hline غير دالة ل & $1,1 \mathrm{r}$ & $0,9 \leqslant$ & $r q, \cdot v$ & $0,7 \pi$ & $r \cdot, 79$ & التفكير المرن & $\varepsilon$ \\
\hline$\cdot, \cdot 1$ & ז, т.- & 7,1 . & עיד, זr & $0, \leqslant 0$ & $r \cdot, v_{0}$ & التفكير فى التفكير & 0 \\
\hline$\cdot, .0$ & T,0T & $r, \wedge 0$ & $T V, I V$ & $r, v r$ & $r \wedge, 01$ & الاجتهاد من أجل الدقة & 7 \\
\hline$\cdot, \cdot 1$ & $r, 0 \tau_{-}$ & $\varepsilon, r$. & $r \wedge, 7 q$ & $\varepsilon, 1 Y$ & $r \wedge, r q$ & التساؤل وطرح المشكلات & 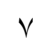 \\
\hline$\cdot, \cdot 1$ & ґ,乏৯- & 7,1 . & 偌 & $0, \ldots$ & $r \cdot, \Lambda$ & تطبيق المعارف السابقة & $\wedge$ \\
\hline 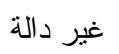 & $\cdot, Y_{Y-}$ & $7, \cdot \varepsilon$ & ४१,१९ & 0,01 & rq, VV & التفكير و التو اصل بوضو ح ودقة & 9 \\
\hline$\cdot, \cdot 1$ & $\Gamma, \wedge \wedge-$ & $7,1$. & (עד, Tr & $0, \varepsilon$. & $r \cdot, \Sigma V$ & جمع البيانات باستخدام الحو لس & 1. \\
\hline$\cdot, .0$ & $r,\{1$ & r,人o & $r V, I V$ & $r, \uparrow \Lambda$ & $Y \wedge, \Sigma \vee$ & التصور و التخيل و الابتكار & 11 \\
\hline غير دالة & $1,00-$ & $0, \wedge 1$ & $r q, \leqslant q$ & $7, \cdot V$ & $r \wedge, 1 \wedge$ & الثغف للتعلم & ir \\
\hline$\cdot, .0$ & r,Tו- & $7,1$. & Tr,TV & $0,1 \mathrm{r}$ & 1,07 & الإقدام على المخاطر المسئولة & r \\
\hline 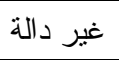 & $1,1 r$ & $0,9 \leq$ & $r q, \cdot v$ & $0,7 \pi$ & $r \cdot, \cdot$, & التحلي بروح الدعابة & $1 \varepsilon$ \\
\hline$\cdot, \cdot 1$ & $r, 09-$ & $7,1$. & (tיד & $0,1 \leqslant$ & M, OV & التفكير التبادلى & 10 \\
\hline 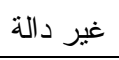 & $\cdot, 11$ & $0, \cdot r$ & rr, Ir & 7,11 & rT,IT & الاستعد اد للتعلم المستمر & 17 \\
\hline$\cdot, .0$ & $-Y, I V$ & $0 ., 0$ & $0 \cdots, \wedge \varepsilon$ & $\varepsilon r, \wedge \uparrow$ & 纟ᄉr,l. & عادات العقل ككل & \\
\hline
\end{tabular}

كما توجد فروق ذات دلالة إحـصائيا

عند مستوى(0 • , ·) بين الطلاب و الطالبــات يتضـح من نتــائج الجــدول الــسابق

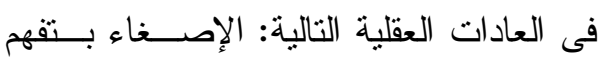

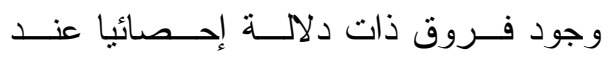

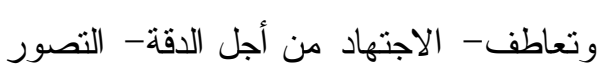

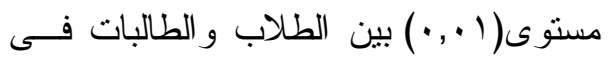

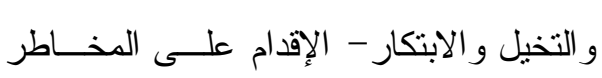

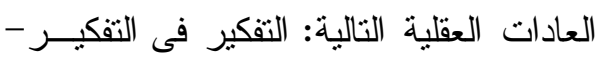
المسئولة) و عادات العقل ككل. التساؤل وطر ح المشكلات- تطبيق المعارف

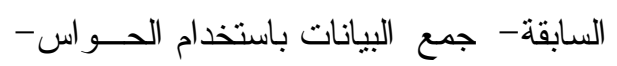
وكانت هذه الفروق لصالح الطالبــات التفكير التبادلى).

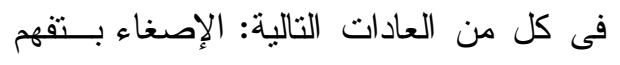




$$
\begin{aligned}
& \text { المطلوبة منهم، وصو لا للمعايير المطلوبــة، } \\
& \text { وتعاطف - التفكير فـى التفكيــر - التــساؤل } \\
& \text { كما أن وجود وقت فر اغ كبير لديهم يمكــنهم } \\
& \text { وطرح المشكلات- تطبيق المعارف السابقة- } \\
& \text { من الوصول إلى حلول جديــدة ومبتـــــرة } \\
& \text { للمشكلات التى يتعرضون لها. } \\
& \text { كما يتضح من نتائج الجدول الــسابق }
\end{aligned}
$$

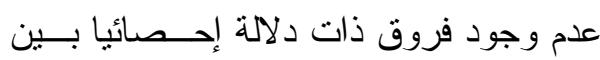

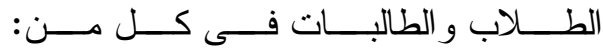

$$
\begin{aligned}
& \text { عادات(المثابرة- إدارة الاندفاعية- التفكيـر }
\end{aligned}
$$

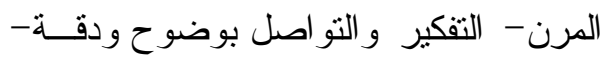

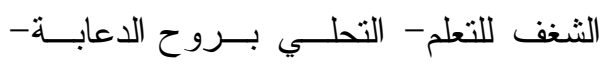

$$
\begin{aligned}
& \text { الاستعداد للتعلم المستمر ). } \\
& \text { وربما يرجع ذلك إلى أن هذه العادات }
\end{aligned}
$$

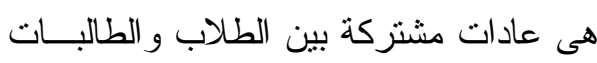

$$
\begin{aligned}
& \text { يحتاج إليها كل منهما فى دراسته وفى حياته }
\end{aligned}
$$

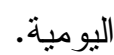

$$
\begin{aligned}
& \text { وتختلف هذه النتيجة جزئيا مع ما } \\
& \text { توصلت إليه دراسات كل من: (سميلة }
\end{aligned}
$$

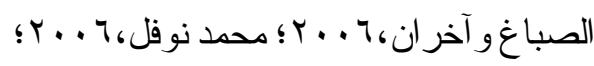

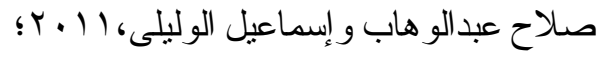

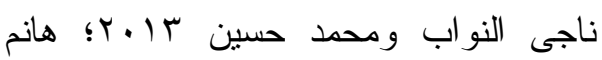

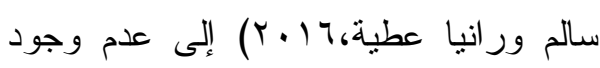

$$
\begin{aligned}
& \text { فروق فى عادات العقل بين الطلاب }
\end{aligned}
$$

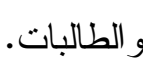


بمرونة و التفكير حول التفكيــر، وجـــاءت

$$
\text { الفروق لصالح الذكور • }
$$

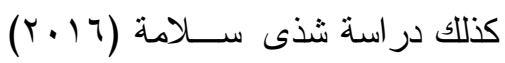

التى أثنارت إلى ظهور تأثنر عامل النوع في عادة التحكم بالتهور لصالح الإناث، و التساؤل وطرح المشكلات لصالح الذكور ، ودر اســة

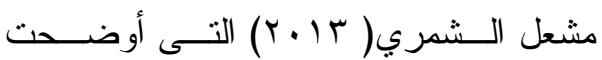
وجود فروق بين الذكور والإناث في عادات التحكم بالتهور، التساؤل وحل المــشكلات، إيجاد الدعابة، الاستعداد الدائم للتعلم المستمر ،
وجدت اختلافا في بعض عادات العقل وفقـا للنوع (ذكور - إناث) منها:

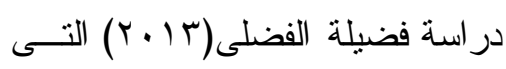
توصلت إلى عدم وجود فروق بين الــذكور و الإناث فى كل عادات العقل ماعـــدا عـــادة التفكير حول التفكير ، كانت الفروق لـصالح

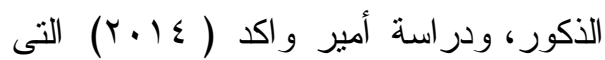
أشنارت إلى عدم وجود فروق إحصائيا فـي عادات العقل تعــزى للانــوع الاجنتـــاعي (ذكور - إناث)، باســنتناء مجــالي التفكيــر و التفكير التبادلي لصالح الذكور .

ثانيا: الفروق بين الأكور والإناث فى كل من: الأكاء الروحى، والدافعية التعلم جدول(· (1)

الفروق بين الأكور والإناث فى كل من: الذكاء الروحى، والدافعية التعلم

\begin{tabular}{|c|c|c|c|c|c|c|c|c|}
\hline \multirow{2}{*}{ مستوى الدلاةة } & \multirow{2}{*}{ قالمحسو "ت" } & \multicolumn{2}{|c|}{ إناث (ن = r r I I) } & \multicolumn{2}{|c|}{ ذكور (ن = } & \multirow[b]{2}{*}{ البعد } & \multirow[b]{2}{*}{ المقياس } & \multirow[b]{2}{*}{ b } \\
\hline & & الالحر اف & المتوسط & الآحر اف & المتوسط & & & \\
\hline$\cdot, \cdot 1$ & $7, O Y-$ & $0,0 \leqslant$ & Vע, Tr & $7, \cdot 7$ & $r \wedge, r \wedge$ & الوعى & \multirow{6}{*}{$\begin{array}{l}\bar{y} \\
\text { a } \\
\overline{3} \\
3\end{array}$} & 1 \\
\hline$\cdot, \cdot 1$ & $\varepsilon, Y O-$ & $0, \leqslant 0$ & & $0, V \leqslant$ & r., & النعمة & & r \\
\hline غير دالة & $1, r_{1}$ & $0, \vee 0$ & $r, \wedge$, & r,oV & rr, & المعنى & & r \\
\hline$\cdot, .0$ & $1,94-$ & r,vA & $r \cdot, r_{1}$ & $\varepsilon, 1 Y$ & $r q, 1 \leq$ & التسامى & & $\varepsilon$ \\
\hline غير دالة & $1, \wedge 1-$ & $\varepsilon, \wedge 9$ & rr, rA & 7, ro & $r \cdot, \wedge$. & الحقيقة & & 0 \\
\hline غير دالة & $\varepsilon, Y_{Y-}$ & $1 \wedge, 7$. & $10 r, 0 \leqslant$ & I A, rV & $1 \leqslant 1, \varepsilon r$ & الأكاء الروحى & & 7 \\
\hline غير دالة & $\cdot, \vee 9$ & $19, r$. & $1 M 1,0 \leqslant$ & $1 \wedge, 7 \leq$ & سז, & الا الدعية للتعلم & \multirow{3}{*}{ 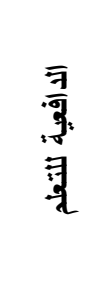 } & V \\
\hline$\cdot, .0$ & $r, 1$. & Y),V $V \leq$ & $\mid \cdots, \times 1$ & $I V, V \varepsilon$ & $1.7,07$ & الا الخعية للتعلم & & $\wedge$ \\
\hline غير دالة & ( & ro,r & TrY, YO & $r \wedge, \cdot \wedge$ & rro, qV & الدافعية للتعلم & & 9 \\
\hline
\end{tabular}




$$
\begin{aligned}
& \text { وفيما يتعلق بــالفروق بــين الـــكور } \\
& \text { يتضح من الجدول السابق عدم وجود }
\end{aligned}
$$

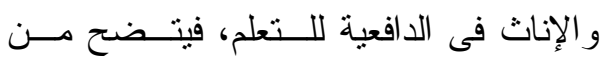

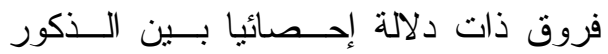

$$
\begin{aligned}
& \text { الجدول السابق عدم وجود فروق ذات دلالـــة } \\
& \text { و الإناث فى الدرجة الكليــة علــى مقيــاس إسل }
\end{aligned}
$$

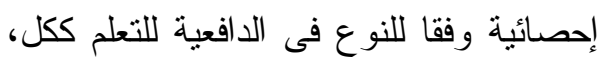

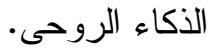

$$
\begin{aligned}
& \text { وتتفق هذه النتيجة مع نتيجة دراسات وفى الدافعية الداخلية. } \\
& \text { وتتفق هذه النتيجة مع نتائج دراســـة لـانة }
\end{aligned}
$$

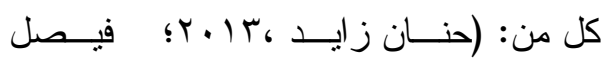

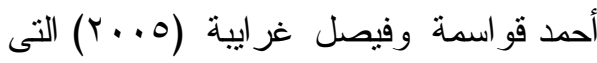

$$
\begin{aligned}
& \text { أشارت إلى عدم وجود فروق دالة إحــصائيا }
\end{aligned}
$$

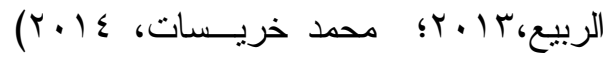

$$
\begin{aligned}
& \text { عدم وجود فروق بينهما فى الذكاء الروحى. } \\
& \text { فى الدافعية للتعلم وفقا للنوع (ذكور - إناث). } \\
& \text { كما يتضح عدم وجود فــروق دالـــة } \\
& \text { وتختلف نتيجة الدراسة الحالية مع ما }
\end{aligned}
$$

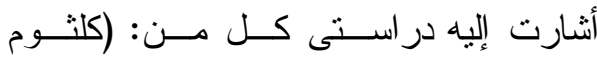

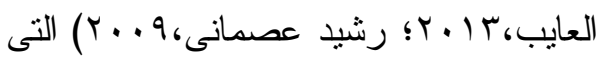

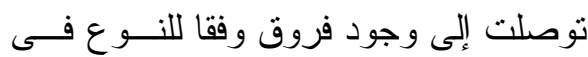

$$
\begin{aligned}
& \text { الدافعية للتعلم لصالح الإناث. } \\
& \text { ويمكن تقسير هذه النتيجة بأن كل من الن }
\end{aligned}
$$

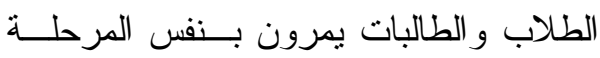

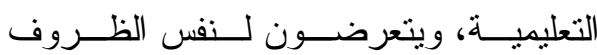

$$
\begin{aligned}
& \text { و المــؤثر ات ويو اجهـــون نفـس التحــــيات }
\end{aligned}
$$

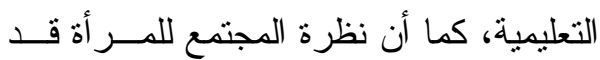

$$
\begin{aligned}
& \text { تغيرت، فأصبح يعترف بالمساو اه بين المر أة }
\end{aligned}
$$

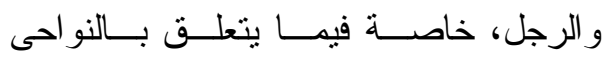

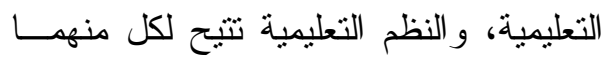

$$
\begin{aligned}
& \text { إظهار قدر اته و إمكاناته. } \\
& \text { كما يتضح من الجدول السابق وجود }
\end{aligned}
$$

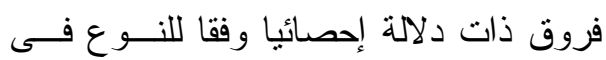

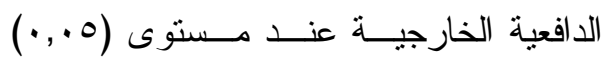

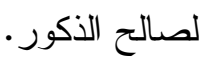

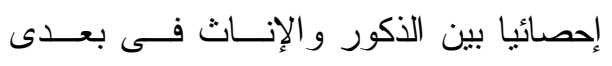

$$
\begin{aligned}
& \text { المعنى و الحقيقة. } \\
& \text { وتختلف نتيجة الدر اسة مـــع أثنــارت } \\
& \text { نتائج در اسة (Tirri et al., 2005 ؛ بشرى }
\end{aligned}
$$

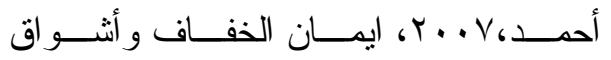

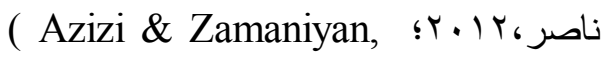

$$
\begin{aligned}
& 2013 \text { فى وجود فروق فى الذكاء الروحسى }
\end{aligned}
$$

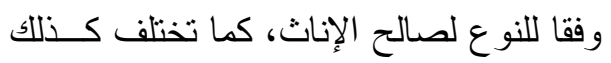

$$
\begin{aligned}
& \text { مع نتيجة در استى كل من: Neto et al., ) } \\
& 2008 \text {; Gupta,2012) } \\
& \text { وجود فروق فى الــذكاء الروحسى لـــالح }
\end{aligned}
$$

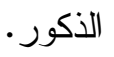

$$
\begin{aligned}
& \text { وفيما يتعلق بــالفروق بــين الـــكور }
\end{aligned}
$$

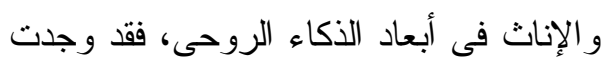

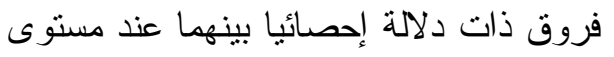

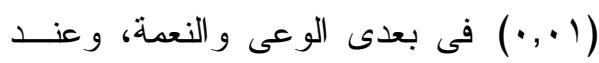

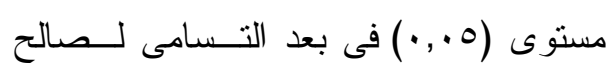


العقل و الذكاء الروحى لــــى طــلاب كليـــة

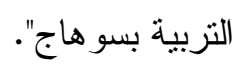

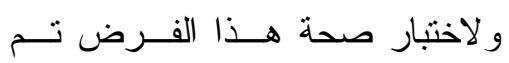

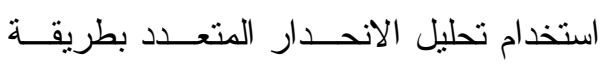

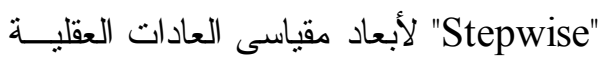

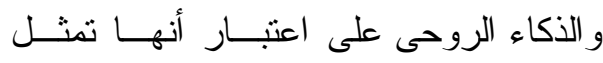
المتغير ات المستقلة، لمعرفة مدى إسهامها فى اعى لمع

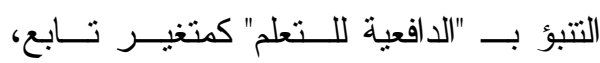

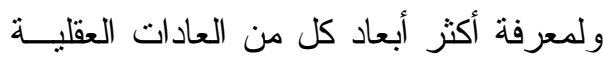

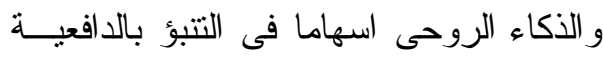

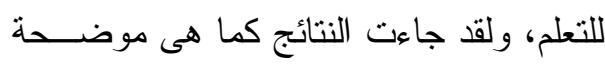

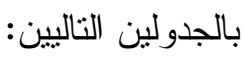

وقد يرجع ذللك إلى نظرة المسساو اة

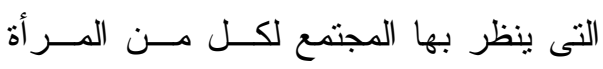

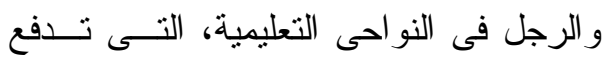
الرجل إلى إثبات ذاته وتأكيد جدارته وتقدمه

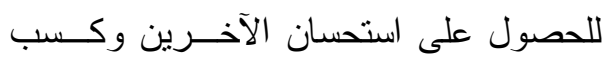

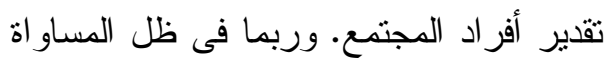

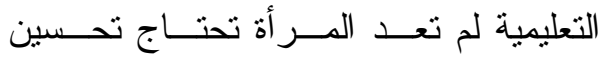

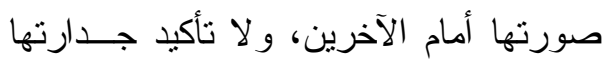
بعدما تقلدت أرفع المناصب. نتائج الفرض الخامس وتفسيرها:

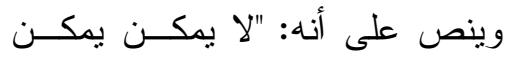

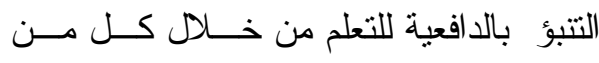
خلال درجات الطلاب على كل من عــادات

جدول (11) نتائج الاتحدار المتعدد للا (فعية للتعلم والمتغيرات المستقلة للارسة

\begin{tabular}{|c|c|c|c|c|c|c|}
\hline $\begin{array}{l}\text { التحليد } \\
\text { (R2) } \\
\end{array}$ & $\begin{array}{c}\text { معامل الارتباط المتعد) } \\
\text { (R) } \\
\end{array}$ & $\begin{array}{c}\text { الإحصائية } \\
\text { Sig. } \\
\text { Sig. }\end{array}$ & $\begin{array}{c}\text { قيمة فية } \\
\text { F } \\
\end{array}$ & $\begin{array}{c}\text { متوسط المربعات } \\
\text { MS }\end{array}$ & | مجموع المربعات & $\begin{array}{l}\text { النموذج } \\
\text { model }\end{array}$ \\
\hline \multirow{3}{*}{$\cdot, 109$} & \multirow{3}{*}{$\cdot, r q \wedge \mathbf{a}$} & \multirow{3}{*}{$\cdot, \cdot}$, & \multirow{3}{*}{$* * v r, r \Delta$} & rrq07,17 & rrq04,14 & الاحدار \\
\hline & & & & $\Lambda \wedge r, \xi \vee$ & $1 \vee \leqslant \vee \curlyvee \wedge, 19$ & البو اقى \\
\hline & & & & & $r \cdot V \neg \Lambda \leq, r q$ & لمجموع \\
\hline \multirow{3}{*}{ •, } & \multirow{3}{*}{., $\{09 \mathrm{~b}$} & \multirow{3}{*}{$\cdot, \cdot}$, & \multirow{3}{*}{ צ } & YIQYI,OV & $\varepsilon r \wedge \leq r, 1 \leq$ & الاحدار \\
\hline & & & & $\wedge \mu 1, \uparrow \wedge$ & $|r r \wedge \leqslant 1, r|$ & البو اقى \\
\hline & & & & & $r \cdot V \backslash \wedge \leq \varepsilon, r q$ & لمجموع \\
\hline \multirow{3}{*}{ - } & \multirow{3}{*}{$\cdot, \leqslant \wedge q \quad c$} & \multirow{3}{*}{$\cdot, \cdot 1$} & \multirow{3}{*}{ 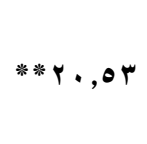 } & $170 \leqslant 9, \wedge r$ & $\leqslant 97 \leqslant 9, \leqslant 0$ & الاحدار \\
\hline & & & & $\Lambda \cdot \neg, r$. & $101 . r \leq, 91$ & البو اقى \\
\hline & & & & & $r \cdot V \backslash \wedge \leq \varepsilon, r q$ & لمجموع \\
\hline
\end{tabular}

a

b=b المنبئات (الاستعداد للتعلم المستمر ، الثغف للتعلم). المنبئات (الاستعداد للتعلم المستمر ، الثغف للتعلم ،النعمة). C المتغير التابع (الدافعية للتعلم). 


\begin{tabular}{|c|c|c|c|c|c|c|}
\hline \multicolumn{7}{|c|}{ معاملات الاتحدار المتعدد ودلالتها الإحصائد ( r I) } \\
\hline مستوى الدلاية & قيمة "ث" & $\begin{array}{c}\text { معامل الاحصدار } \\
\text { المعيارى }\end{array}$ & الخطأ & $\begin{array}{l}\text { معامل } \\
\text { (B) }\end{array}$ & النموذج & \\
\hline$\cdot, \cdot 1$ & $M, \wedge \wedge$ & & Ir,rV & $109, \mathrm{r} \wedge$ & | لمقدار الثابت & \\
\hline$\cdot, \cdot 1$ & 7,11 & $\cdot, \Sigma$ & $\cdot, \Gamma \wedge$ & r,ret & 1 - الاستعد/د للتعلم المستصر & الأول \\
\hline$\cdot, \cdot+1$ & $1 \cdot, r \wedge$ & & $|r, \Sigma|$ & $\mid r V, \wedge \varepsilon$ & الدقدار الثابت & \\
\hline$\cdot, \cdot 1$ & $\varepsilon, \varepsilon q$ & $\cdot, \mu_{1}$ & $\cdot, \varepsilon \cdot$ & $1, \vee \wedge$ & 1 - الاستعد/د للتعلم المستصر & الثنانى \\
\hline$\cdot, \cdot 1$ & rז, & $\cdot$, , YO & $\cdot, r v$ & 1, I & r- الشغف للتعلم & \\
\hline$\cdot, \cdot 1$ & $\wedge, \wedge \Gamma$ & & $1 \leq, 1$. & $\mid r \leq, 0$ & الدقدار الثابت & \\
\hline$\cdot, \cdot 1$ & $r, 1$. & $\cdot, r r$ & $\cdot, \leqslant \Gamma$ & I,rr & 1 - الاستعد/د للتعلم المستصر & 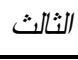 \\
\hline$\cdot, \cdot 1$ & r,q. & $\cdot, r \cdot$ & $\cdot, \mathrm{r} \wedge$ & $1, .9$ & r- الشغف للتعلم & \\
\hline$\cdot, \cdot 1$ & $r, \Upsilon \wedge$ & $\cdot, 19$ & $\cdot, 11$ & 1,1 & r- - النعدة(الذكاء الروحى) & \\
\hline
\end{tabular}

صياغة معادلة التتبؤ بالمتغير التابع(ص =

كما بتضح من نتائج الجدول السابق الدافعية للتعلم)، بمعلومية المتغير ات المستقلة

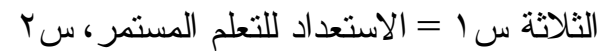

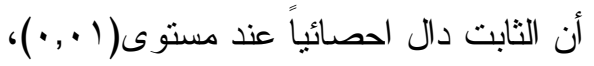

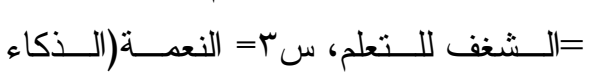

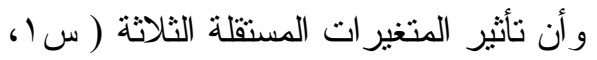

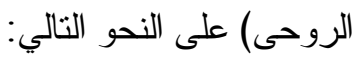
س ץ، سب) على المتغير التـابع( ص)دال

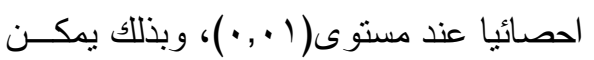

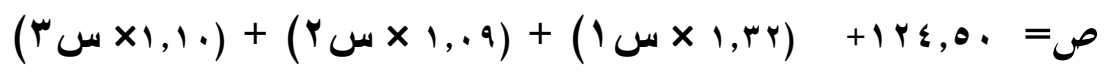
يمكن الحكم على صـــلاحية نـــوذج يشير هذا النموذج إلى: الانحدار المقدر من خلال التعليق على نتائج

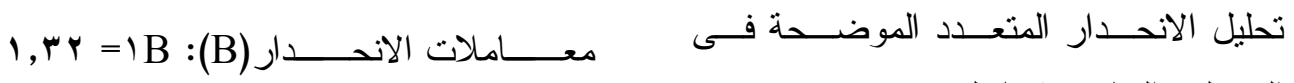
$1,1 .=r B ، \quad 1, \cdot 9=r B$ ، الجدولين السابقين كما يلى: 
دافعيته للتعلم، وبالتالى فمن خلال معرفتتـــا بهذه الأبعاد الثلاثة (الاستعداد للتعلم المستمر فئل

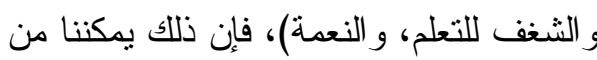
التتبؤ بدافعيته للتعلم.

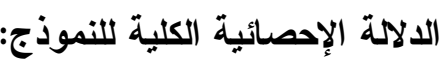
يوضح جدول (11) الـــى يتـــن تحليل التباين أن قيمة "ف" المحسوبة نساوى

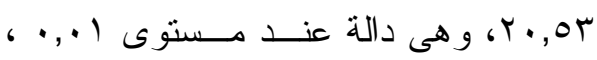
ومن ثم فإن نموذج الانحدار دال إحـــائياً،

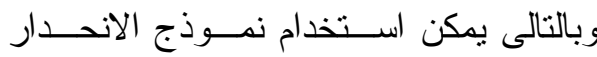

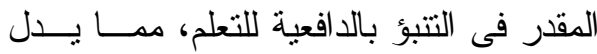
على تحقق الفرض الحالى. الدلالة الإحصائية الجزئية للنموذج: يتضح من جدول (Y l) و المتــمن

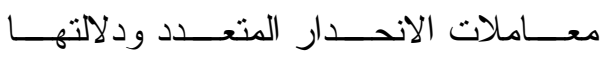

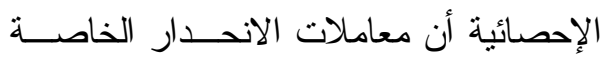

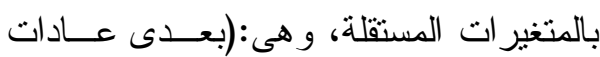

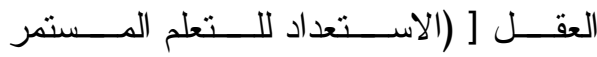

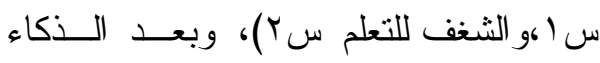

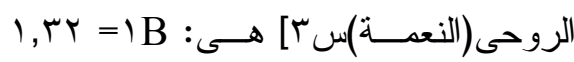
r B،

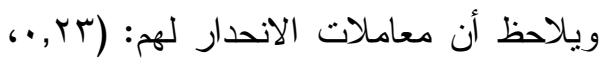

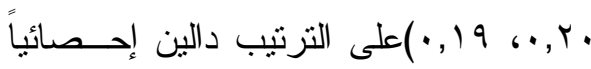

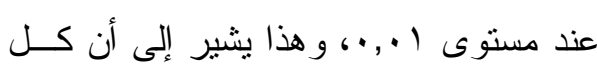

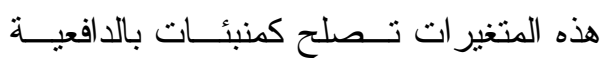
للتعلم.

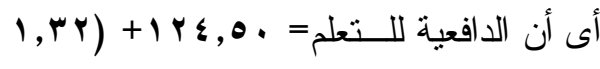

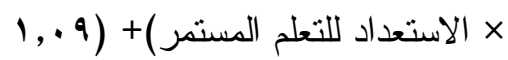

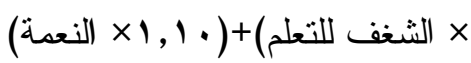
وتوضح هذه المعادلة أنه كلما ارتفعت درجات الطلاب على الثلاثة أبعـاد التاليــة: بعدى عادات العقل (الاستعداد للتعلم المستمر

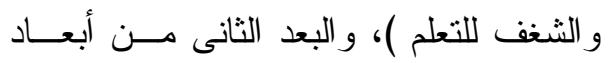
الذكاء الروحى (النعمة)، ارتفعت الــدرجات على مقياس الدافعية للتعلم. القدرة التفسيرية للنموذج: يشير جدول (1)

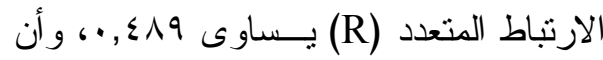

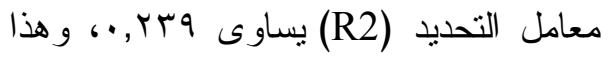

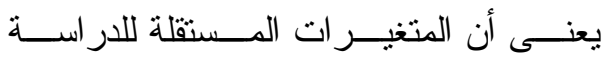

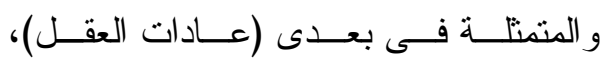

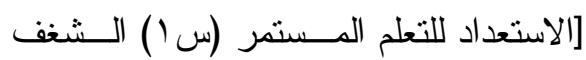
للتعلم (س r) ، وبعد الذكاء الروحى( النعمة)

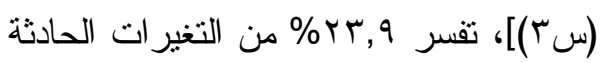

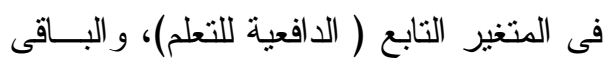

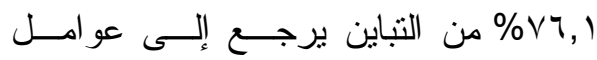
أخرى. ويمكن تفسير هذه النتيجة بأن الفــرد

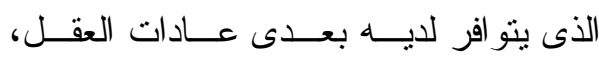

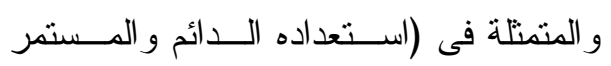
للتعلم، وشغفه وحبه للتعلم)، بالإضافة إلـى ولى ولى

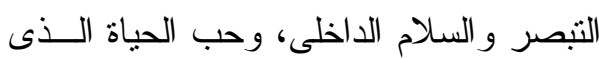
يعكسه بعد(النعمة) فإن ذلك يسهم فى زيسـادة ولئ 


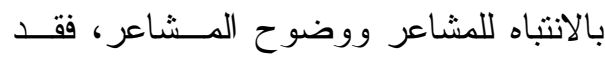
ينتبه الفرد لمشاعره وقد يظل هـــاهـ الانتبــاه

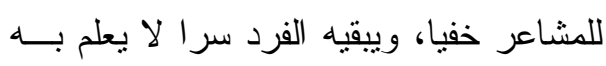
أحد غيره، كما أنه يمكن للفرد تعديل مز اجه

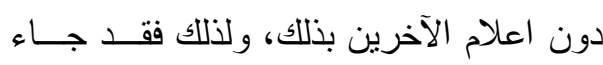

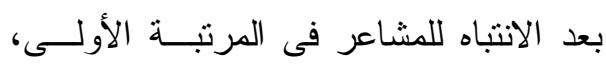
وتعديل المزاج فى المرتبة الثانية.

ونتقق هذه النتيجة مع مــــا اشـــارت

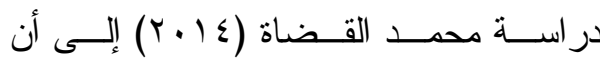
العادات العقلية المتمثلة فى: القيادة، الابداع،

الحيوية أسهوت فى التتبؤ بالدافعية للانجاز •

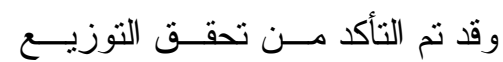

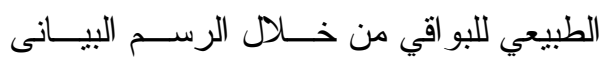

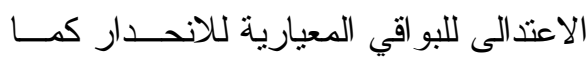

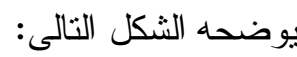

وبالتالى يكون ترنيب هذه الأبعاد وفقا

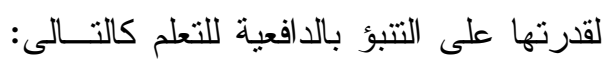

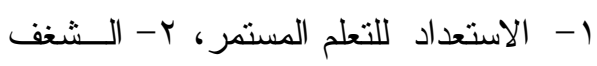

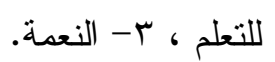

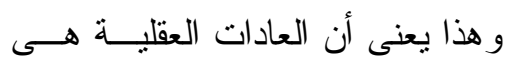
المحرك لدافعية التعلم، حيث ارتبطت الدرجة الدان

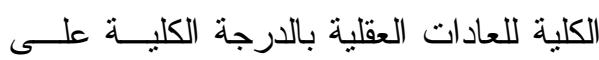
الدافعية للتعلم.

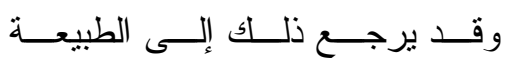

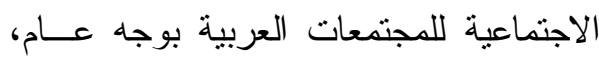

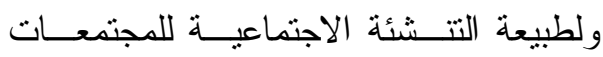

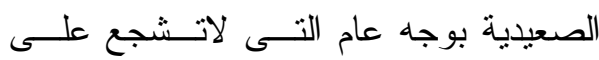

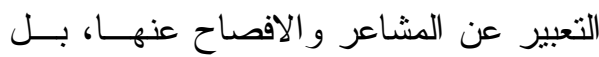

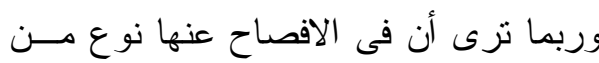

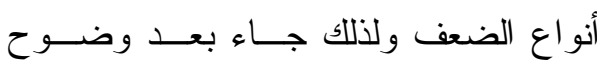

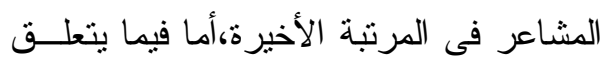
شكل (ا) التوزيع الطبيعي للبو اقي

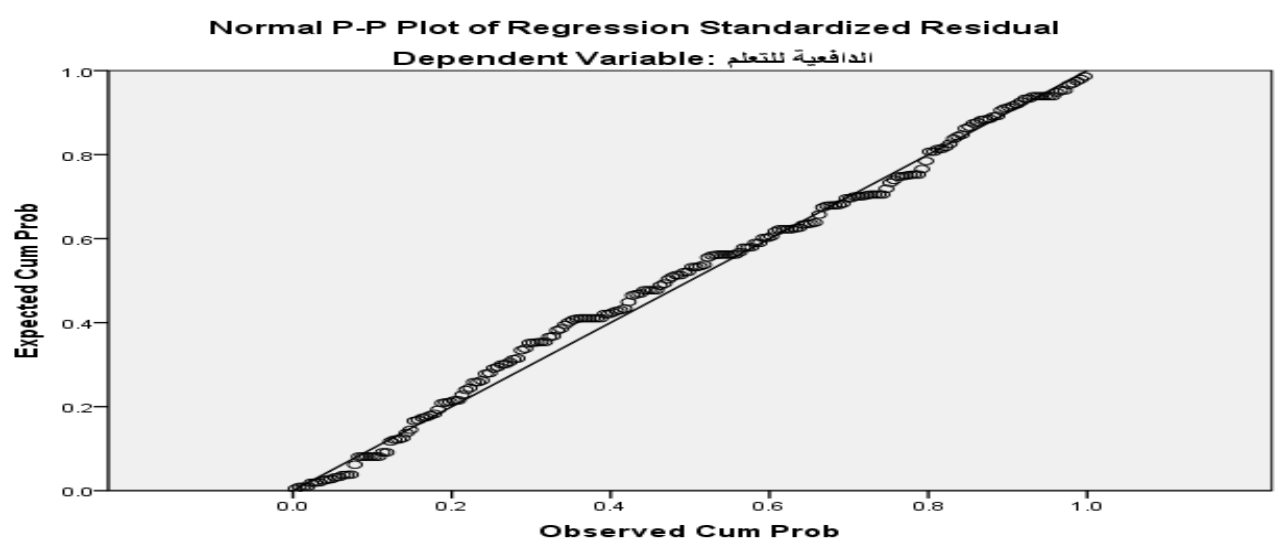

ويوضح المدرج التكرارى التالى أن البيانات تتبع التوزيع الطبيعى، وهو يحقـق شــرط تحليل الإنحدار 


\section{شكل (ץ) المدرج التكرارى للبيانات}

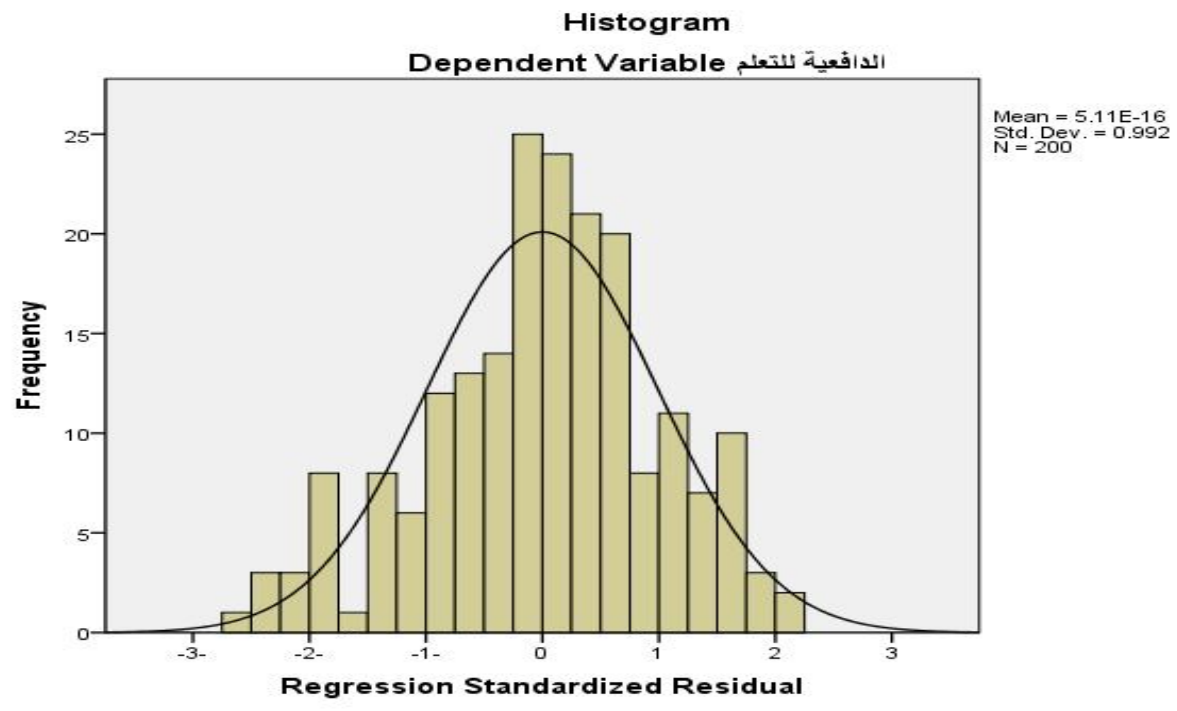

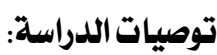

ـ - تهيئة البيئة و المناخ التعليمى الـــاعم

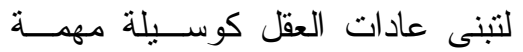

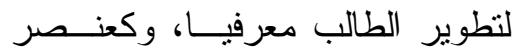

فعال ورئــيس فــى تتميــة الدفعيــة

للتعلم.

0ـ التطوير المــستمر لاعـضـاء هيئــة

التدريس ومعاونيهم داخل الجامعسات

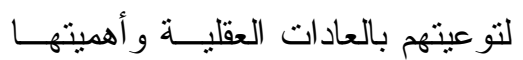

و العمل على الكثثف عنها، وتتميتهــا

$$
\text { لدى الطلاب. }
$$

7- تصميم بر امج تدريبية لتتمية عسادات

$$
\text { العقل لاى الطلاب. }
$$

فى ضوء ما أسفرت عنه نتـــائج الدراســة الحالية، توصى الباحثة بما يلى:

1 ا ـ تعديل وتطوير المقــررات الجامعيـــة بكليات التزبية لتتضمن جو انب نركز

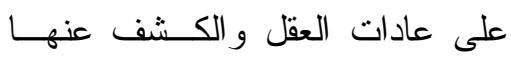
وطرق تتميتها.

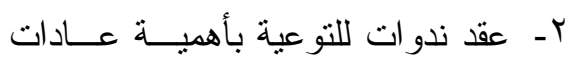
العقــل ولــــكاء الروحــى ووســائل

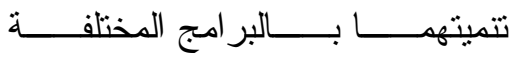
و المنتو عة.

بـ - الاهتمام بالأساليب و الطرق المختلفـــة التى تعمل على زيادة الدافعية للــتعلم

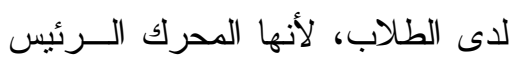
للنشاط و النجاح و التفوق. 
طلاب وطالبات كلية التربيــة جامعــة

الزقازيق. مجلة كلية التربيــة جامعــة

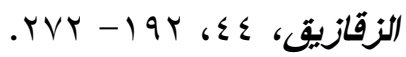

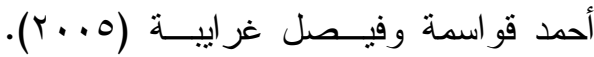

دافعية التعلم للطلبة وعلاقتهـــا بــبعض العو امل الأسرية. مجلة العلوم التريوية، $.19 T-I V V 6 V$

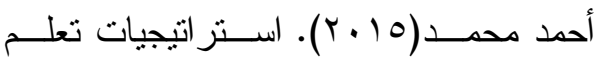

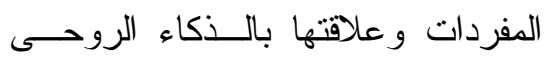

و التحصيل الدر اسي لدى متعلمى اللغـــة

العربية كلغة ثانية. دراســات تربويسـة

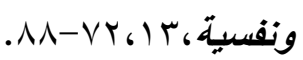

اصلان المساعيد(11 + r). مستويات عادات

العقل عند طلبة الصف العاثر في ضوء

متغير الجنس. مجلة جامعسة الـشارقة

للعلــوم الإ_سـسانية والاجتماعيــة، 1

$. r \cdot 9-191,(r)$

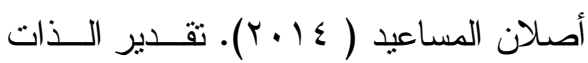

و علاقته بدافعية التعلم لدى طلبـــة كليــة

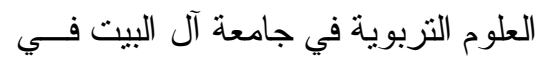

ضوء بعض المتغير ات. مجلة المنـــارة

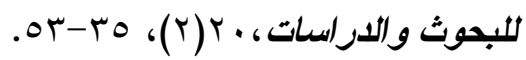

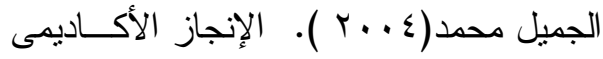

و علاقته بمستوى الطموح ومفهوم الذات

و الحاجة للمعرفة لــدى طــلاب كليــة المعلمين بمكة المكرمة دراسة نتبؤيـــة.
تقتر ح الدر اسة الحالية البحوث التالية:

1- العلاقة بين عادات العقل و الاحتـــراق

التعلىى و التفكير المنفتح النشط.

r- الذكاء الروحى فى علاقتـــه بالكفـــاءة

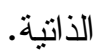

ع- برنامج تدريبى لتتمية بعض العـادات

العقلية.

ه- العلاقة بين عادات العقل و المعتقـــات

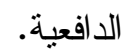

צ- العلاقة بين الذكاء الروحى و التسويف

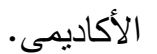

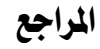

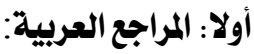

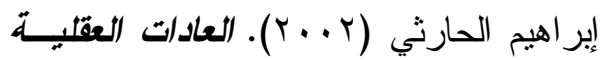
وتنميتها لدى التلاميذ. الرياض: مكتبة

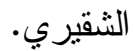

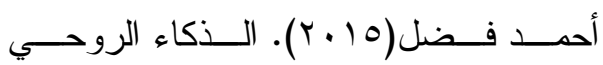

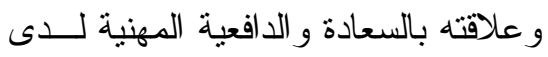

عينة من معلمي المرحلــة الابتدائيــة.

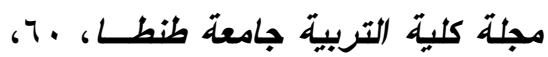

$$
\text { . } ₹ 09-r q .
$$

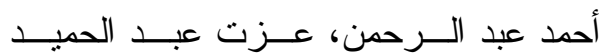

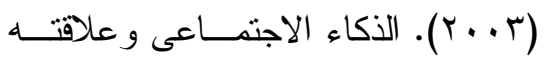

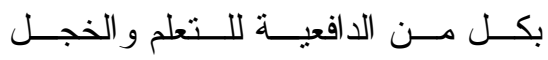

و الثجاعة و التحصيل الدراسـى لـــى لـى ولـ 
المستقبل.الإسماعيلية. فندق المرجان، . $\{7 \leqslant-4 q)$ 。

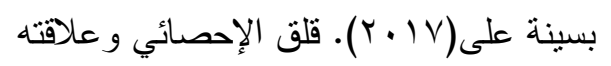
بالدافعية للتعلم و التحصيل الدر اسي لدى الدى

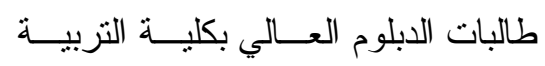

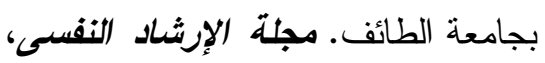
.90-or ، 9

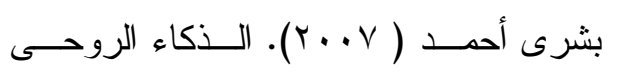
و علاقته بسمات الثخصية لاى عينـات عمرية مختلفة. مجلـــة كليـة التربيــة

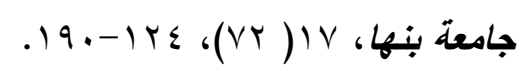

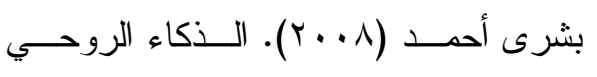

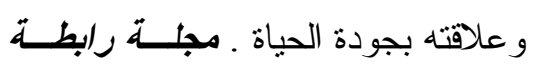

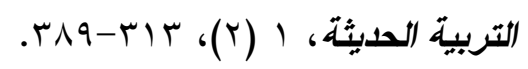

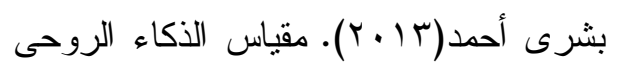

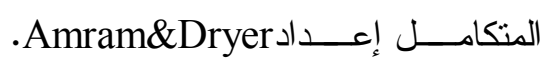
تعريب وتقنين: بشرى إسماعيل.القاهرة: مكتبة الأنجلو المصرية.

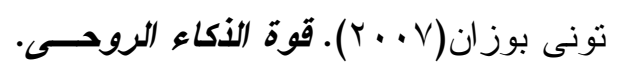
الرياض: مكتبة جرير.

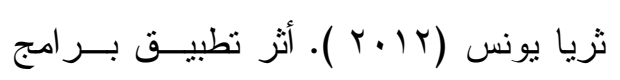

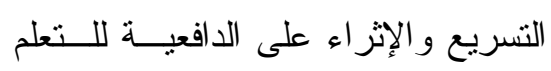
و التحصيل وتقدير الذات لــدى الطلبــــة الموهوبين في الأردن. مجلــة جامعــة القلس المفتوحة للبـــوث الإنسسانية

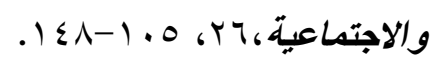

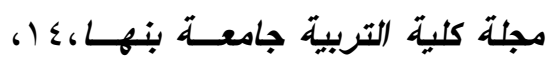

$$
\text { .r. I- IVA }
$$

أمل قاسم(10 • ب). الذكاء الروحى و علاقتــــ

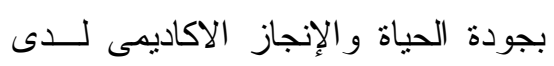
الطالبات المعلمــات بالجامعــة. مجلـــة

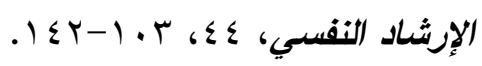
أمير و اكد( ؟ ا • ب). عادات العقل و علاقتها

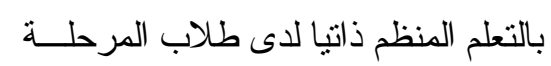
الثانوية في عكا. رسالة ماجستير غيسر منشورة. كلية العلوم التزبوية و النفسية. جامعة عمان العربية. عمان. الأردن.

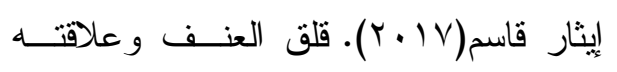

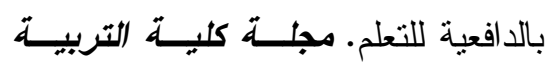

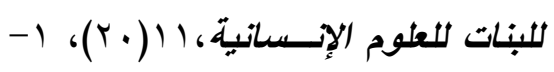
.49 ايمان الخفاف و أثتــواق ناصــر ( r I ب). الذكاء الروحى لدى طلبة الجامعة. مجلة

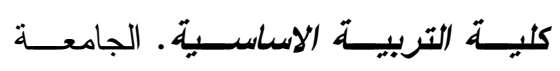
المستتصرية، V0، VVV

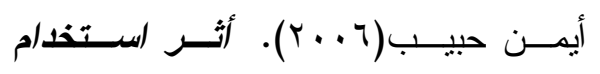
استراتيجية (حلل - اسأل -ستتقصي )

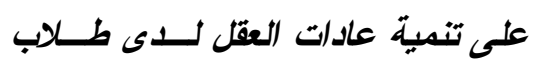
الصف الأول الثانوي من خــله مــادة الكيمياء. المؤتمر العلمي العانشر التربية

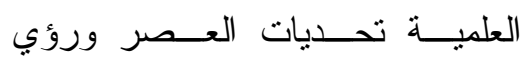




$$
\begin{aligned}
& \text { عبد الحميد جابر و آخرون. القاهرة: دار } \\
& \text { قباء للطباعة و النشر و التوزيع. }
\end{aligned}
$$

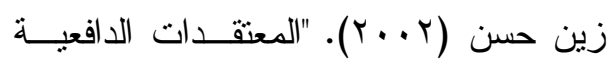

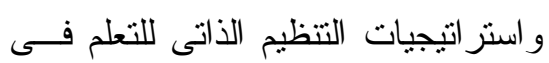

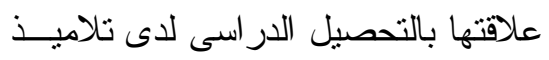

$$
\begin{aligned}
& \text { مدارس منار ات المدينة المنورة". مجلة }
\end{aligned}
$$

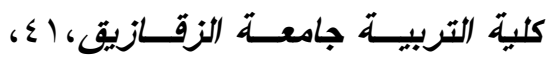

$$
\begin{aligned}
& \text {. } r \text { r }
\end{aligned}
$$

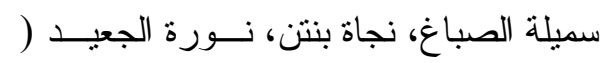

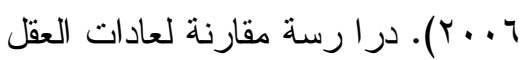

$$
\begin{aligned}
& \text { لدى الطلبة المتفوقين في المملكة العربية }
\end{aligned}
$$

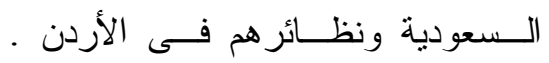

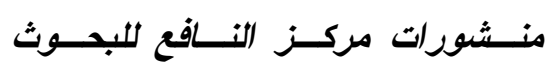

$$
\begin{aligned}
& \text { والاستشارات التربوية. الأردن. } \\
& \text { سها منولى ومحمد عبدالغفار ونادية أبو دنيا }
\end{aligned}
$$

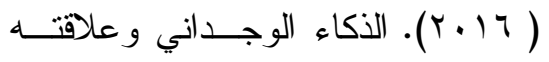

$$
\begin{aligned}
& \text { بالدافعية للتعلم لــدى طــلاب التعلــيم }
\end{aligned}
$$

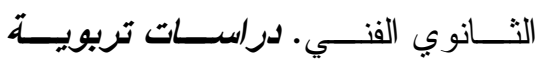

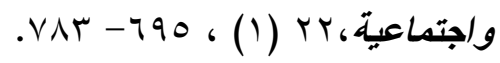

$$
\begin{aligned}
& \text { سبلفر وسترونج (T · . ץ). تكامل الــكاءات } \\
& \text { المتعددة وأساليب التعلم. نرجمة: مراد } \\
& \text { عيسى، وليد أحمــــ. الإســكندرية: دار } \\
& \text { الوفاء للطباعة و النشر . }
\end{aligned}
$$

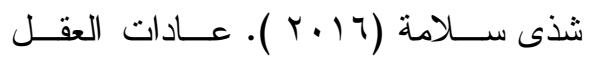

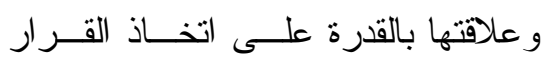

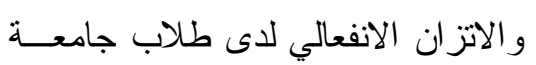


عبد العزيز الثخص ومحمـــود الطنطــاوى وظافر الثهر انى( (10 • ب). برنامج قائم

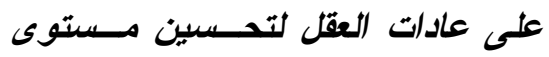
التحصيل الدراسي لدى المتفوقين عقليا منذفضى التحصيل. رسالة دكتور اه غير منشورة. كلية النزبيــة. جامعــة عــين شمس.

عمر حجاج (乏 ا • Y). الأمن النفسي وعلاقته بالدافعية للتعلم. مجلة العلوم الإ_سـسانية

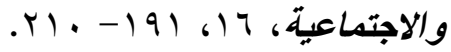
عمرو شريف (1) (1). رحلة عقـل . طع. القاهرة: مكتبة الثروق الدولية.

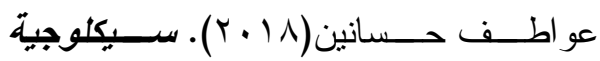
القــــرات العقليـــة والتكــــين العقلــــى الموهبة والإبـــاع. الجيـزة: المكتبـــة الأكاديمية. فضيلة الفضلى( ( ا • Y). عادات العقل المنبئة بكفاءة الذات الأكاديمية لاى طلبة كليــة التزبية جامعة الكويت. مجلة الطفولـــة

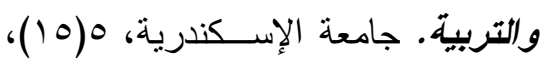
$. \Sigma \Lambda V-\varepsilon r V$

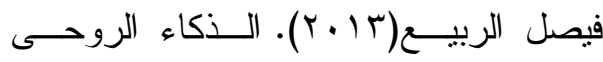
وعلاقته بالجنس ومستوى التحصيل لدى

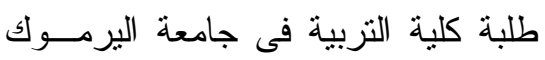

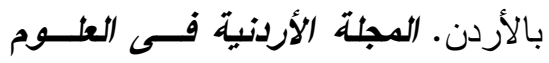

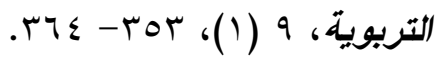

مؤتــــهـ .رســالة ماجـستير غيــر منشورة.جامعة مؤتة، عمان. الأردن. صالح العلى (T + . r). أثر الدافعية فى التعلم عند برهان الإسلام الزرنوجى فى كتابه تعليم المتعلم طريق التعلم. مجلة اتحسـاد

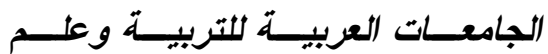

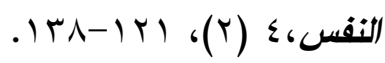
صلاح الدين محمود (T . . r). تفكيـر بـلا حدود رؤى تريوية معاصرة في تعلــيم التفكير وتعلمه . القاهرة: عالم الكتب. صلاح عبد الوهــاب و إبـــماعيل الـــوليلى (Y) (1). العلاقة ما بين كل من عادات العقل المنتجة و الذكاء الوجدانى وأثز ذلك على التحصيل الدر اسي لــدى طـــلاب المرحلة الثانوية من الجنسين. مجلة كلية التربية بالمنصورة، TV، . rY-90 ب. رشيدة عصمانىى(9 . . ب). الدافعيــة للــتعلم

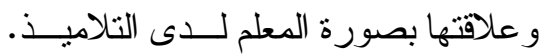
مجلــة كليــاتة العلــوم الإنسانسية

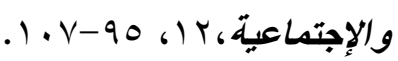

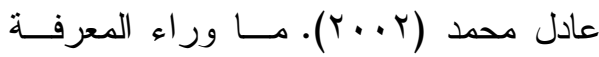
و الدافعية و استر اتيجيات التتظيم الــذاتى التى لاى العاديين وذوى صـــوبات الــتعلم. مجلة كلية التربية جامعة عين شعس،

$$
. \vee \wedge-9 \text { ، (1) r }
$$




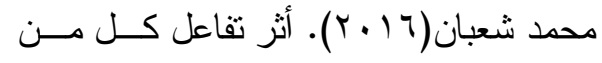

الذكاء الروحي و السعادة على جودة حياة

العمل لاى عينة مــن معلمــي التزبيـــة

الخاصة در اسة إمبريقية. دراسات عربية مبنة

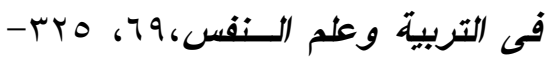

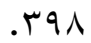

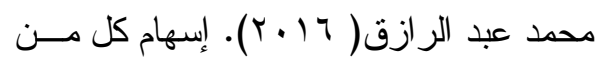

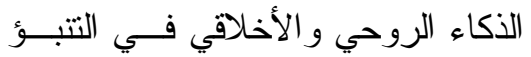

بالكفايــات الثخــصية لــدى معلمــي

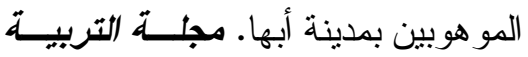

الخاصة جامعة الزقازيق، بحس- r؟ ــ.

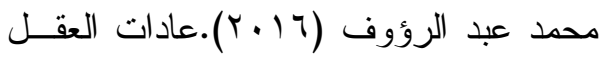

المنبئة بالتقكير الجانبى. دراسات عربية

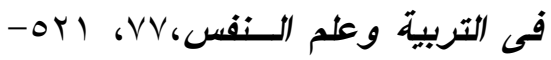

$.0 \mathrm{VO}$

محمد نوفل (0 · ب). تطبيقات عملية فــي

تنمية التفكير باستخد/م عادات العقـل.

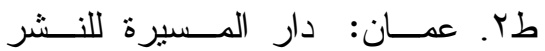

$$
\text { و التوزيع. }
$$

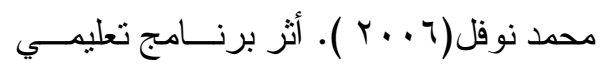

مستتد إلى نظرية الإبداع الجاد في تتمية

الدافعية العقلية لاى طلبة الجامعة مـن

ذوي السيطرة الدماغية اليسرى. رسالة

ماجستير غير منشورة، الأردن: كليــة

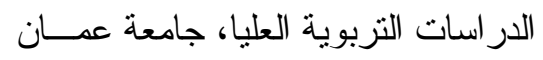

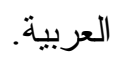

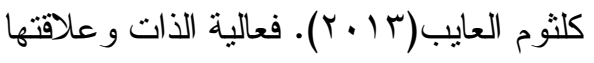

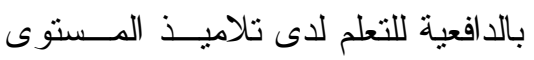

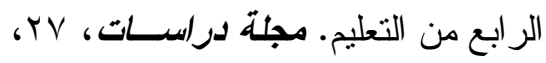

$$
.1 V V-101
$$

كمال عطية (........ العلاقة بـين أبعـاد

التعلم الكنظم ذاتيا ، دافعيــة الــتعلم و

التحصيل الدر اسي لاى طالبــات كليـــة

التزبية بعبرى ســلطنة عمــان. مجلـــة

البحوث النفسية والتربوية. كلية التربية

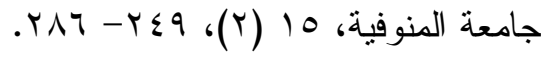

كو ستا وكاليك (T . . . ) ). استكشاف وتقصى

عادات العقل. ترجمة: مدارس الظهران الأهلية. الدمام: دار الكتاب.

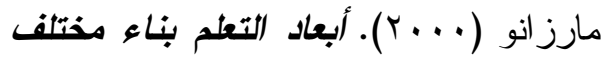
للفصل الدراسس • ترجمة: جـابر عبـــ الحميد. القاهرة: دار قباء.

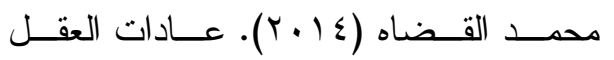
و علاقتها بدافعية الإنجاز لــدى طــلاب كلية التربية بجامعة الملك سعود. المجلة العربية لتطوير التفــوق،ه (^) ، ،بـ.09

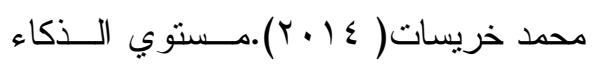
الروحي لدى عينة من طلبة كلية الحصن الجامعية التابعة لجامعة البلقاء التطبيقية فـي الأردن. مجلـــة التربيــة جامعــة

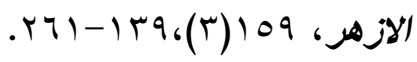


نسرين عر ابى وشيماء البلاشــونى وشــادية

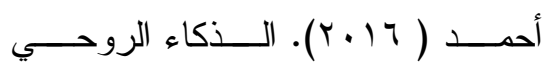
و علاقته بدافعية الإنجــاز و التحــصيل التوديل

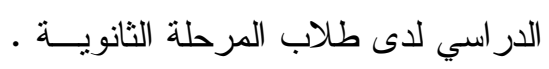
مجلة البحث العلمي في التربية. كليــة

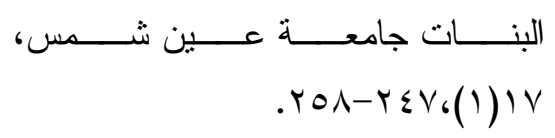

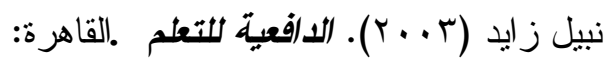
مكتبة النهضة المصرية.

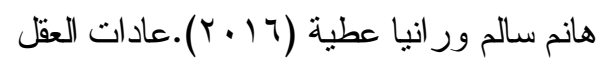

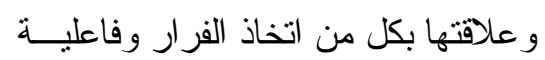
الذات لدى الطلاب المتفوقين و العـاديين بالصف الأول الثانوي العـام. مجلـــة

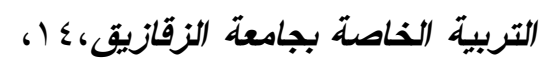
$.11 r-0$. هبة محمد (T ( ب). برنامج قائم على التعلم

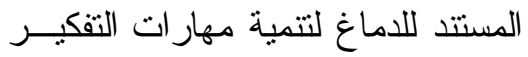
الجغر افي و الدافعية للتعلم لتلاميذ المرحلة الابتدائية. مجلـــة الجمعيــة التربويســة

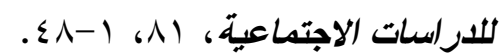

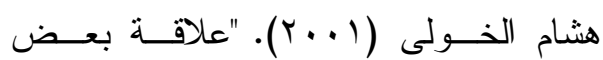
جو انــب الدافعيــة الدر اســية بتفــضيل المخاطرة و اتخاذ القر ار لــدى طـــلاب

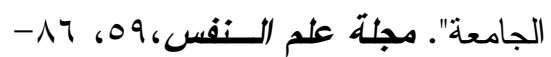
.ITY
محمود الطنطاوى( (Y) IV). عادات العقـل و علاقتها بالاحتر اق النفــسي و الدافعيـــة نحو العمل لاي معلمي الإعاقة الفكرية. مجلة التربية الخاصة والتأهيل، (Y) (Y) .101-9r.

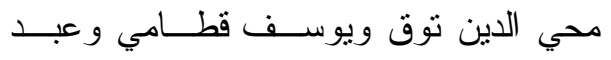

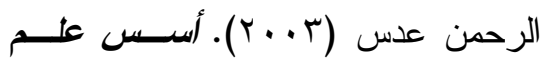

النفس التريوي. الطبعة الثالثة، عمــان: دار الفكر للطباعة و النشر و التوزيع.

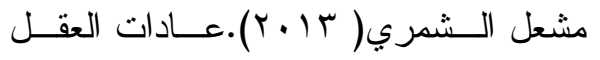

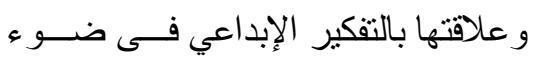
النوع و التخصص لـى بلى الطلاب فــائقي

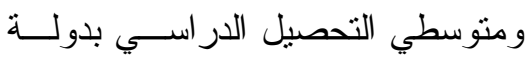
الكويت. رسالة ماجستير غير منشورة، بكلية الدر اسات العليا، جامعسـة الخلــيج العربي، البحرين. ناجى النو اب، محمد حسين( r ( • ب). عادات

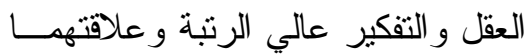
بالفاعلية الذانية لاى طلبة كليات التزبية.

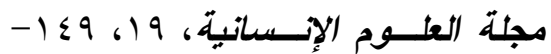
.$I V T$ نداء هادى وزينب بديوى (Y V (Y). الذكاء الروحي لدى طلبة الجامعسـة المرتفعـي لهـي و المنخفضي التحصيل الدر اسي. مجلـــة

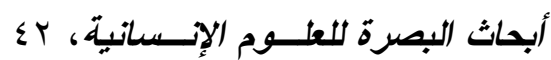

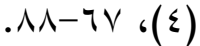


presented at the AARE Annual conference. Adelaide, 1-20.

Culler, A. (2007). From dropouts to higher achievers habits of mind. $\mathrm{PhD}$ thesis, ED. 344718 , U.K.

Davis, J. \& Wilson, S. (2000). "Principals' efforts to empower teacher: effects on teacher motivation ad job satisfaction and stress". The Clearing House, 73, 349-353.

Emmons, R. (2000). Spirituality and intelligence: problems and prospects.

International Journal for the Psychology of Religion, 10(1), 57-64.

George, M. (2006). Practical application of spiritual Intelligence in the workplace. Human resource management international digest, 14(5), 35.

Gupta, G. (2012). Spiritual Intelligence and Emotional Intelligence in Relation to Selfefficacy and self- regulation among college students.

International Journal of Social Sciences\& Interdisciplinary, research, 1 (2), 60- 69.

Hyerle, D. (1999): Visual tools and technologies designs for Thinking. New York: Lyme.NH.

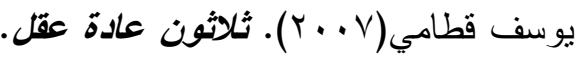

$$
\begin{aligned}
& \text { عمان: دار ديبونو للنشر و التوزيع. }
\end{aligned}
$$

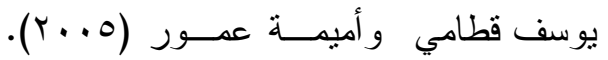

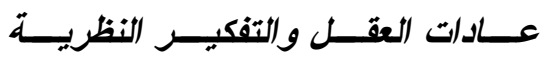

$$
\begin{aligned}
& \text { والتطبيق. عمان: دار الفكر للنشر . }
\end{aligned}
$$

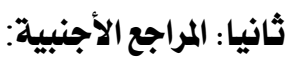

Amram, Y. (2007). What is Spiritual Intelligence? An Ecumenical Grounded Theory. New York: Palo Alto, CA.

Amram. Y. \& Dryer, C. (2008).

The Integrated Spiritual Intelligence Scale (ISIS).paper presented at the annual conference of the American Psychological Association. Boston, August 14-17.

Azizi, M., \& Zamaniyan, M. (2013). The Relationship between Spiritual Intelligence and Vocabulary Learning Strategies in EFL Learning. Theory and Practice in Language Studies, 3 (5), 852858

Costa, A. \& Kallick, B. (2000). Discovering and Exploring Habits of mind, Virginia: Association for Supervision and Curriculum Development.

Campbell, J. (2006). Theorising habits of mind as a Frame Work for learning. Paper 
Nobari, L.; Shokri, M. (2014). Evaluating The Student's Spiritual Intelligence, Quality Of Life, and Academic Achievement Motivation Relationship at Payam-E-Noor University in Kaleibar Branch. Arabian Journal of Business and Management Review, 3(12), 127-131.

Raftopoulos,M. \& Bates,G. (2011). It's that knowing that you are not alone the role of sprirituality in adolescent resilience, international journal of children's spirituality, 16 (2), 151-167.

Selman, V.; Selman, R.; Selman, J. \& Selman, E. (2005). Spiritual-Intelligence/Quotient. College Teaching Methods \& Styles Journal, 1(3), 23-30.

Sisk. D. (2008). Engaging the Spiritual Intelligence of Gifted Students to Build Global Awareness in the Classroom. Report Review, 30, 24-30.

Takahashi, T. (2018). Motivation of students for learning English in Rwandan schools. Issues in Educational Research, 28(1), 168-186.

Tirri, K.; Runnels,M.\& Nokelainen,P.(2005) : Acrosscultural study of preadolescents , moral, religious and spiritual questions, British
Khadivi, A.; Adib, Y. \& Farhanghpour, F.(2014).’Relationship between Spiritual Intelligence, Self- Esteem, and Body Image with Students' Educational Improvement". European Journal of Experimental Biology, 2 (6), 2408- 2414.

King, D.(2008). Rethinking claims of spiritual intelligence: Adefinition, model, and measure. Unpublished Master Thesis. Trent University.

Komarchuk, N.; Swenson, A. \& Warkocki, L. (2000). "Improving secondary student academic success through the implementation of motivational strategies". Educational Resource Information Center. ED. 444087.

Matthew, P. \& Nicole, W. (2002). "Psychometric- properties of the sport motivation scale: an evaluation with college varsity athletes from the U.S.A.". Journal of Sport\& Exercise Psychology, 24 (3), 254- 266.

Neto, F.; Ruiz, F. \& Furnham, A. (2008) .Sex difference in selfestimation of multiple intelligence among Portuguese adolescents. High ability studies, 19 (2), 189-204. 
Vaughan, F. (2002). What is spiritual intelligence?. Journal of Humanistic Psychology, 42 (2), 16-33.

Vibulphol, J. (2016). Students' Motivation and Learning and Teachers' Motivational Strategies in English Classrooms in Thailand. English Language Teaching, 9 (4), 64- 75. journal of religious education , 27 (3), 207-214.

Tishman, S. (2000).Why Teach Habits of Mind? , Alexandria: Association for Supervision and Curriculum Development (ASCD).

Tremmel, R. (2002). A habits of mind. English Education, 24(1) 20-33. 